\title{
Intellectual Property Rights and Institutions: A Pluralist Account
}

\section{Citation}

Kenneally, Michael Edward. 2014. Intellectual Property Rights and Institutions: A Pluralist Account. Doctoral dissertation, Harvard University.

\section{Permanent link}

http://nrs.harvard.edu/urn-3:HUL.InstRepos:12274503

\section{Terms of Use}

This article was downloaded from Harvard University's DASH repository, and is made available under the terms and conditions applicable to Other Posted Material, as set forth at http:// nrs.harvard.edu/urn-3:HUL.InstRepos:dash.current.terms-of-use\#LAA

\section{Share Your Story}

The Harvard community has made this article openly available.

Please share how this access benefits you. Submit a story. 
(C) 2014 Michael E. Kenneally All rights reserved. 


\title{
INTELLECTUAL PROPERTY RIGHTS AND INSTITUTIONS:
}

\section{A PLURALIST ACCOUNT}

\begin{abstract}
Debates over intellectual property's justifications tend to treat natural rights and utilitarian accounts as competitors, but they should be seen as complements instead. Lockean and Kantian theories of intellectual property highlight the strong interests that intellectual property creators have in profiting from and exercising some degree of control over their work, but neither theory gives sufficient justification for the full assortment of rights that intellectual property owners have under current law. Utilitarian accounts provide an essential supplement to these natural rights theories by focusing on society's interests in the production of useful information and creative expression, but that does not mean intellectual property law should single-mindedly strive only to maximize social welfare. Developing both natural rights-based and utilitarian justifications, this dissertation advances a pluralist account of intellectual property that understands different features of copyright, patent, and trademark law to be serving different normative interests.
\end{abstract}




\section{CONTENTS}

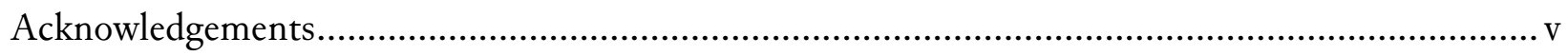

1. On Justifying Intellectual Property Ownership ........................................................................

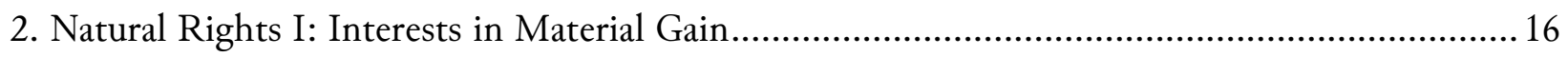

2.1 Lockean Property, the "Meddle" Way .......................................................................... 18

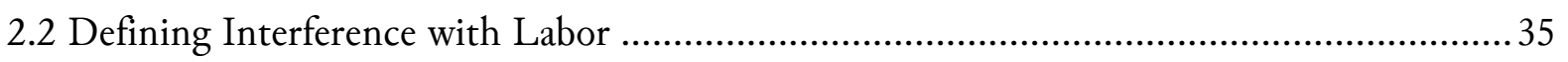

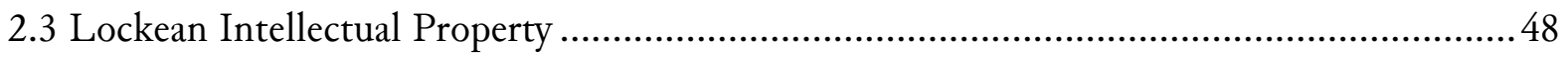

2.4 Alternative Understandings of Lockean Intellectual Property ..............................................55

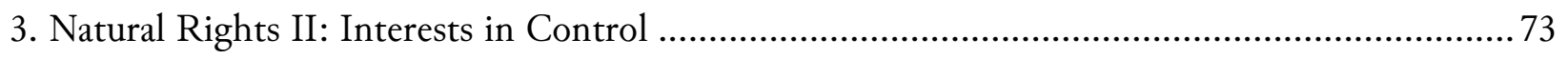

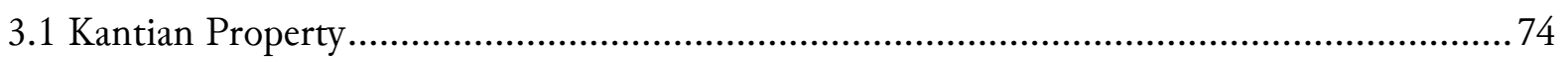

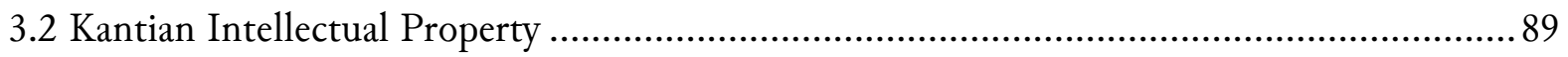

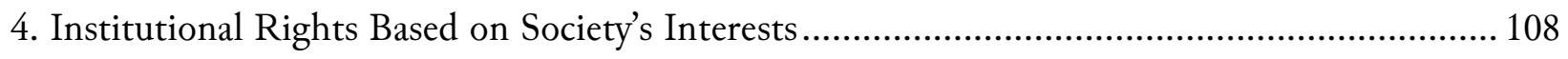

4.1 Intellectual Property Functionalism and Utilitarianism ................................................ 112

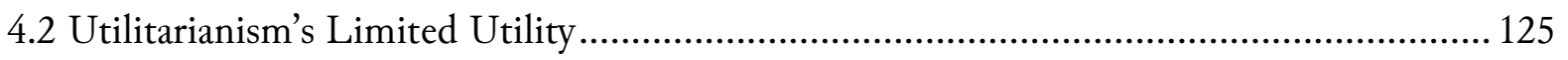

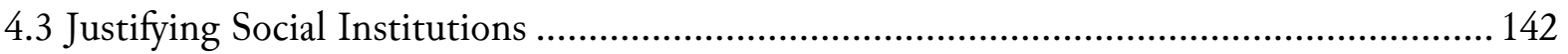

4.4 Functionalist Justification and Private Legal Rights....................................................... 149

4.5 Deriving Rights from Institutions ............................................................................... 167

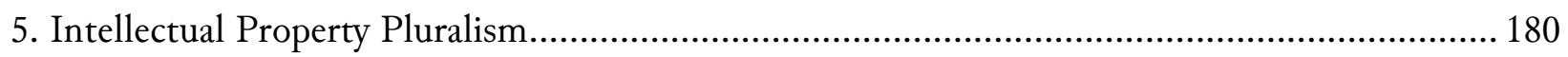

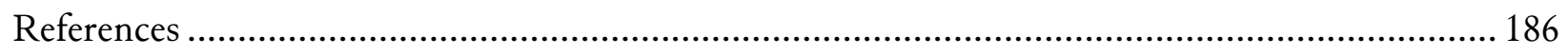




\section{ACKNOWLEDGEMENTS}

Many people supplied invaluable help and encouragement during the writing of this dissertation. I am grateful first and foremost to the members of my committee-Tim Scanlon, Chris Korsgaard, and Doug Lavin from the Harvard Philosophy Department, and Henry Smith from Harvard Law School. Each has taught me a great deal about law and philosophy, and even more about the kind of scholar one should strive to be. And, of course, each has spent lots of time and energy pushing me to make this project as good as I could. It would have been far less good without their advice, if it existed at all. I might never have turned my attention to the philosophical dimensions of intellectual property had Doug not suggested it during my first few months in graduate school.

Thanks are due as well to the Edmond J. Safra Center for Ethics, which offered me financial support and an intellectual home base during a year of the writing. Eric Beerbohm and Frances Kamm led a fantastic seminar at the Center where among other things we graduate fellows could present our in-progress work and solicit feedback. The input I received from them, Richard Fallon, and my fellow fellows all led to a much stronger end result. The same holds at least as much for the Philosophy Department's Workshop in Moral and Political Philosophy, run (while I was enrolled) by my three philosophy advisors and Selim Berker. There too their comments and 
those of my graduate colleagues helped enormously. Patricio Fernandez deserves special mention; he has been a steady friend and sounding board every step of the way.

Last but obviously not least I thank my family: my parents, for giving me a start in this life and making me want to devote so much of it to learning; my wife, for giving me confidence and unyielding support; and my children, for giving all the motivation I could ever need. 


\section{ON JUSTIFYING \\ INTELLECTUAL PROPERTY OWNERSHIP}

The earth and its contents have great importance in the lives of creatures like us, but we disagree, sometimes sharply, about what to do with them. One social response to our disagreement is private property ownership, which empowers specific individuals or groups-owners-to make authoritative decisions about how the things they own may be used. Yet the powers of ownership breed disagreements as well as resolve them, and so philosophers and others have thought long and hard about private property ownership's justifications. Today, physical objects are no longer the only kind of privately owned things. Intellectual property ownership shapes modern life to nearly as great an extent as physical property ownership, and the nonphysical things it regulates have extraordinary importance of their own. Not surprisingly, then, intellectual property ownership generates plenty of controversy too, and its justifications warrant careful attention.

To date, however, philosophers have devoted relatively little attention to intellectual property ownership as such. There are at least two possible explanations, the first of which is merely historical. Compared to its earthier relative, intellectual property ownership is a very young social institution. One can find scattered examples of very old laws whose effects are quite close to intellectual property laws'. In ancient Sybaris, for instance, someone who accomplished outstanding culinary feats was reportedly entitled to be the only authorized maker of the award-winning dish 
for a period of one year. ${ }^{1}$ This rule, though, seems to have been more a Sybarite idiosyncrasy than part of a systematic effort to protect intellectual property. For such efforts, at least in the West, we have to wait until early modern Europe. As the printing press and other technologies spread across the continent, so too did Europeans' pleas to their governments for recognition as the sole lawful makers of specific goods. Many of these pleas were individually answered, but it was not until 1474 that lawmakers set out to create general rules for the granting of such privileges. That was the year Venice enacted the first known patent legislation, which allowed the inventor of "any new and ingenious" device to obtain a decade-long exclusive privilege to make it. ${ }^{2}$ Venetian copyright legislation followed in the 1500 s. $^{3}$ England followed a similar path slightly later. Its sovereigns routinely bestowed royal privileges, or letters patent, on favored subjects, and Parliament ultimately responded in 1624 with the Statute of Monopolies, which authorized fourteen-year patents for new inventions. ${ }^{4}$ Several different statutes regulated the printing industry prior to the 1710 Statute of Anne, which created a copyright for books lasting a maximum twenty-eight years. ${ }^{5}$ People have been placing their distinctive marks on goods for thousands of years, but trademark ownership's beginnings seem to coincide with the beginnings of patent and copyright ownership. ${ }^{6}$ And not

${ }^{1} 3$ Athenaeus, The Deipnosophists bk. 12, ch. 20, at 835 (C.D. Yonge ed. \& trans., London, Henry G. Bohn 1854) (c. 230).

${ }^{2}$ Giulio Mandich, Venetian Patents (1450-1550), 30 J. Pat. OfF. SoC'Y 166, 177 (1948).

${ }^{3}$ See, e.g., Horatio F. Brown, The Venetian Printing Press 73-82 (New York, G.P. Putnam's Sons 1891).

${ }^{4}$ See, e.g., Ramon A. Klitzke, Historical Background of the English Patent Law, 41 J. PAT. OfF. SoC'Y 615, 626-35, 649 (1959).

${ }^{5}$ See, e.g., Lyman Ray Patterson, Copyright in Historical Perspective 143-50 (1968).

${ }^{6}$ See, e.g., Gerald Ruston, On the Origin of Trademarks, 45 Trademark Rep. 127, 140-41 (1955). 
until the last century did all these forms of intellectual property become an unavoidable feature of everyday life. Compared to physical property ownership, then, intellectual property ownership is still a youngster, and philosophers' comparative inattentiveness to it might just be a consequence of its youth.

Or the relative scarcity of attention to intellectual property's philosophical grounding could be due to a substantive assumption: what has already been said about physical property ownership can be translated into the intellectual property context easily enough, and so no separate account of intellectual property ownership is necessary. This assumption should be rejected. Intellectual property raises unique issues and deserves philosophical scrutiny in its own right. Familiar accounts of physical property ownership certainly aid our thinking about intellectual property, but they do so by providing starting points, not conclusions. We will see it is not so easy to figure out how justifications for private ownership of physical goods apply to intellectual ones, which are different in significant ways.

Indeed, we encounter difficulties as soon as we get started. For before proceeding to possible justifications, we must first determine just what intellectual property ownership is. The phrase "intellectual property" encourages us to think that we are simply dealing with ownership of one particular species of property-the "intellectual" one. There is some truth to this suggestion because intellectual property ownership, like any kind of ownership, consists in having special entitlements to particular things. These entitlements come in different forms, such as rights and correlative duties, privileges or liberties, and powers to alter the normative situation of others. ${ }^{7}$ But

\footnotetext{
${ }^{7}$ See generally WeSLey NewCOMB HoHFELd, FundAMENTAL LEgAL CONCEPTIONS AS APPLIED IN JUdicial REASONING (Walter Wheeler Cook ed., 1920).
} 
the specific entitlements that make up intellectual property ownership are not the same as the ones that make up physical property ownership. The entitlements of copyright ownership are not even the same as those of patent or trademark ownership. And so we must guard against fallacy when we talk of physical property ownership and intellectual property ownership as different species of a single genus. In particular, because ownership amounts to a different thing in the intellectual property setting, arguments claiming that private ownership of land or moveable objects is justified because certain conditions obtain do not automatically support the conclusion that private ownership of intellectual objects is justified to the extent that the same conditions obtain. ${ }^{8}$ In order to assess intellectual property ownership's justifications, we need to understand what it actually involves. But before we can do that, we should take a closer look at the various kinds of things that can be owned under intellectual property law.

Unlike chattels and realty, intellectual property concerns intangibles. And unlike other intangible property, copyrights, patents, trademarks, trade secrets, and rights of publicity are grouped under the heading intellectual property because they concern valuable kinds of thoughts and imagery. Copyright governs particular ways of expressing ideas, facts, and feelings. Patents and trade secrets regulate useful information. Trademark law restricts the use of symbols of relations

\footnotetext{
${ }^{8}$ The following reasoning, whatever else we might say about it, would be guilty of the fallacy of equivocation: P1. $X$ is a sufficient condition for justified private ownership of physical things.

C1. Therefore, $X$ is a sufficient condition for justified private ownership of any thing. P2. $X$ sometimes obtains in the case of intellectual things.

C2. Therefore, private ownership of intellectual things is sometimes justified.
} 
between commercial goods or services and their source. And rights of publicity concern depictions of people. Because of its intellectual character, it is often true that something an intellectual property owner owns can be used by another person without taking it away from its owner. ${ }^{9}$ If I create a beautiful sculpture for my garden, for instance, someone who stumbles upon it can go on to make a replica for himself while leaving me to enjoy the original. Tangible resources are not often enjoyed by multiple people so painlessly. If the passerby instead takes with him the sculpture itself, not just his impression of it, I am significantly worse off.

One can get a better idea of what intellectual property is by considering paradigm cases. Copyrights essentially cover artistic works - that is, creative and original expressive material that has been fixed in some tangible form. Exemplars include sculpture of course, and painting, photography, musical compositions and performances, films, architectural works, poetry, and prose. ${ }^{10}$ One cannot copyright merely factual information (as opposed to particular expressions of it), ${ }^{11}$ though some discoverers of time-sensitive facts receive temporary protection against freeriding competitors by a cousin of copyright known as the misappropriation doctrine. ${ }^{12}$ Patents and trade secrets, on the other hand, typically do cover factual information. Patents protect information on how to produce copies of a useful, non-obvious invention or how to execute a new, non-

\footnotetext{
${ }^{9}$ Economists frequently say that intellectual property concerns non-rival goods, where non-rivalry means that one person's enjoyment of the good need not threaten anyone else's. There are rare examples of information that characteristically loses value as it becomes widespread, such as stock market tips.

${ }^{10}$ See 17 U.S.C. § 102(a) (2006).

${ }^{11} I d . \S 102(\mathrm{~b})$.

${ }^{12}$ See, e.g., Int'l News Serv. v. Associated Press, 248 U.S. 215 (1918).
} 
obvious process that achieves a useful result. ${ }^{13}$ Famous patents include Eli Whitney's cotton gin, Samuel Colt's revolver, Charles Goodyear's method for vulcanizing rubber, Louis Pasteur's technique for pasteurization, and Alexander Graham Bell's telephone. Trade secrecy law protects much the same sort of information-Coca-Cola's recipe is the classic example-but does so by preventing certain unauthorized disclosures and uses of the information by those who have been let in on the secret or acquired it improperly ${ }^{14}$ rather than by requiring the inventor to disclose the information and then prohibiting unauthorized uses of it, as patent law does. ${ }^{15}$ Trademarks, such as logos, brand names, and distinctive slogans, are symbols representing a connection between commercial products and the particular entities that are their source or endorsers, or occasionally between products and the product line or family of which they are members. Similarly, rights of publicity protect individuals (usually celebrities) from having their name, likeness, or distinctive characteristics used for commercial purposes without permission. ${ }^{16}$ Common rights of publicity lawsuits involve advertisements associating a celebrity with a product, often in a way that misleadingly suggests his or her endorsement. ${ }^{17}$

With these examples of intellectual property in view, we can proceed to take a closer look at what owning intellectual property involves. In his classic account of physical property

\footnotetext{
${ }^{13}$ See 35 U.S.C. $\S \S 101-103$.

${ }^{14}$ UnIF. TRADE SECRETS ACT $§ 1(1),(2),(4)$ (amended 1985).

${ }^{15}$ See 35 U.S.C. $\S \S 112,271$.

${ }^{16}$ See, e.g., Haelan Labs., Inc. v. Topps Chewing Gum, Inc., 202 F.2d 866, 868 (2d Cir. 1953).

17 See, e.g., Waits v. Frito-Lay, Inc., 978 F.2d 1093 (9th Cir. 1992).
} 
entitlements, A.M. Honoré looked to property law to identify "standard incidents of ownership"not necessary conditions for ownership so much as constituents of a somewhat idealized form of "full" ownership. ${ }^{18}$ So too can we find guidance about what intellectual property ownership is in the various bodies of intellectual property law. A detailed account of the rights, privileges, and powers set out in different intellectual property doctrines would fill a good many pages, but to get started scrutinizing the justifications for intellectual property ownership a sketch of its standard incidents will do. As with physical property, rights relating to use and disposition are at the core of intellectual property ownership. ${ }^{19}$ But the use and disposition of intellectual things are in key respects unlike the use and disposition of physical ones. Therefore, in order to develop an idealized conception of intellectual property ownership it is necessary to examine how the concepts of use and disposition operate in intellectual property law.

Let us consider use rights first. Property owners may use their property almost any way they like so long as they do not harm others. ${ }^{20}$ This feature of property law is just a privilege in Wesley Hohfeld's terms; the law neither prohibits use nor guarantees it. But of course the privilege is supplemented because when it comes to using the resource the owner has pride of place. Thus an owner of physical property has claim-rights against all non-owners that they not unreasonably

${ }^{18}$ A.M. Honoré, Ownership, in OXFORD EsSAYS IN JURISPRUDENCE 107, 107 (A.G. Guest ed., 1961).

${ }^{19}$ Cf. 1 William Blackstone, COMmEnTARIES *138 (claiming that an Englishman's property rights "consist[] in the free use, enjoyment, and disposal of all his acquisitions, without any control or diminution, save only by the laws of the land"). Some accounts of property add "possession," see, e.g., Loretto v. Teleprompter Manhattan CATV Corp., 458 U.S. 419, 435 (1982); RICHARD A. EPSTEIN, TAKINGS 59 (1985), which unlike use and disposition is not straightforwardly applicable in the field of intellectual property.

\footnotetext{
${ }^{20}$ There are, to be sure, important regulations of property use-for instance, through zoning restrictions-but the default is that owners may use their property at their discretion provided they do no harm.
} 
interfere with her use and enjoyment of her property, whether by preventing her from using the property or by making the property less suitable for her use. In practice, owners generally have a privilege to use their resources that is exclusive of everybody else's unauthorized use of them. Call this combined privilege and claim-right "against the world" an excluding privilege. An excluding privilege exists just in case its holder has (1) a privilege to engage in some action and (2) a claimright against virtually all others that they not act in the same way without special permission. For physical resources, this sort of exclusivity serves the important purpose of shielding the owner's uses from others' choices. Trespass law goes even further, though, and not only gives landowners use-priority but also forbids others' unauthorized entry onto privately owned land regardless of whether the entry would impair the owner's use of the land.

In intellectual property, the owner's exclusive privileges are more like this right against unauthorized entry in the law of trespass to land than like a mere right against interference with owner use. The law marks a great many uses of intellectual property off-limits for everyone but their owners, and not just when use by a non-owner would hinder use by the owner. Patent law's use prohibition seems to sweep very broadly at first glance: anyone who "uses" a patented invention (without the owner's permission) is an infringer. ${ }^{21}$ Trademark law prohibits only certain sorts of use, such as using a protected mark commercially in a manner likely to confuse consumers. ${ }^{22} \mathrm{~A}$ clear-cut example would be the unauthorized placement of a protected mark on commercial products that are of the same type as the mark owner's own products—-think of fake Louis Vuitton

\footnotetext{
${ }^{21} 35$ U.S.C. § 271(a) (2006).

${ }^{22}$ See 15 U.S.C. § $1114(1)$.
} 
bags. Copyright law forbids making new copies of the copyrighted work. ${ }^{23}$ Patent law targets duplication separately, prohibiting everyone but the patentee from producing individual incarnations of a patented invention. ${ }^{24}$ The reason why patent law includes a prohibition on making as well as one on using simpliciter is that the latter is heavily qualified by a venerable doctrine known as patent exhaustion, which basically holds that a patentee's intellectual property rights with respect to a particular article embodying his patented invention are exhausted as soon as he sells the product. ${ }^{25}$ Thanks to patent exhaustion, someone who bought an incandescent electric light from Thomas Edison would have been mostly free to use it notwithstanding Edison's patent, but would not have been free to replicate Edison's light bulb after theirs had burned out. So although intellectual property owners generally have a privilege to use the owned resource (subject to the usual laws prohibiting harm to others), ${ }^{26}$ this privilege turns out not to be theirs alone because the law permits many non-owner uses of intellectual property. The quintessential way intellectual property owners receive special use-rights is through an excluding privilege to embody the thing they own in tangible objects or actions. On any account, this excluding privilege should be listed as a standard incident of intellectual property ownership.

\footnotetext{
${ }^{23}$ See 17 U.S.C. $\S 106(1)$.

${ }^{24} 35$ U.S.C. $§ 271(\mathrm{a})$.

25 See, e.g., Quanta Computer, Inc. v. LG Elecs., Inc., 553 U.S. 617, 625-28 (2008).

${ }^{26}$ The privilege to use is not explicitly recognized by patent law, and in fact it is possible for an inventor to obtain a patent but be "blocked" or prohibited from using his invention because doing so would infringe another person's preexisting patent. See, e.g., Cantrell v. Wallick, 117 U.S. 689, 694 (1886).
} 
But embodying the very thing an intellectual property owner owns is not the only way to use her intellectual property unlawfully. Copyright law, for instance, also forbids making new works that closely resemble the original protected work ${ }^{27}$ as well as those that are derived from it, including translations into different languages or adaptations for new media. ${ }^{28}$ Trademark law likewise prohibits use not only of the exact logo, slogan, or brand name that someone else has previously been using to identify his commercial products or services, but similar ones as well if they are likely to confuse consumers. ${ }^{29}$ Moreover, regardless of the likelihood of consumer confusion, using famous marks or close variants in association with products unrelated to the trademark owner's own products qualifies as trademark dilution if the unauthorized use weakens the distinctiveness of the original trademark ${ }^{30}$ or tarnishes its referent's reputation. ${ }^{31}$ These copyright and trademark prohibitions are relaxed by doctrines of "fair use," 32 which among other things permit parody and criticism even when these derive from the privately owned work. ${ }^{33}$ And patent law actually allows making new versions of patented inventions: patents protect only the

\footnotetext{
${ }^{27}$ Such works are said to be "substantially similar" to the original copyrighted work. See, e.g., Comptone Co.v. Rayex Corp., 251 F.2d 487, 488 (2d Cir. 1958) (per curiam).

${ }^{28}$ See 17 U.S.C. $\S \S 101,106(2)$.

${ }^{29}$ See, e.g., McLean v. Fleming, 96 U.S. 245, 253 (1877).

${ }^{30}$ See, e.g., 15 U.S.C. § 1125(c)(2)(B); Hyatt Corp. v. Hyatt Legal Servs., 736 F.2d 1153 (7th Cir. 1984).

${ }^{31}$ See, e.g., 15 U.S.C. § 1125(c)(2)(C); V Secret Catalogue, Inc. v. Moseley, 605 F.3d 382 (6th Cir. 2010).

32 See, e.g., 15 U.S.C. §§ 1115(b)(4), 1125(c)(3)(A); 17 U.S.C. § 107.

33 See, e.g., Campbell v. Acuff-Rose Music, Inc., 510 U.S. 569 (1994); Louis Vuitton Malletier, S.A. v. Haute Diggity Dog, LLC, 507 F.3d 252 (4th Cir. 2007).
} 
specific invention claimed in the filing ${ }^{34}$ and barely altered variants made up of equivalent elements. ${ }^{35}$ But taking our cue from copyright and trademark doctrine, perhaps we can still say that full ownership of intellectual property would include an excluding privilege to develop it.

In addition to these two use-focused incidents of intellectual property ownership, intellectual property law standardly recognizes disposition-focused incidents. First, intellectual property owners have certain disposition rights over objects that embody the intellectual thing they own-for instance, the physical books that contain a copyrighted text. Most notably, unauthorized sales of that sort of object qualify as copyright, patent, or trademark infringements over and above any preceding violations of the owner's exclusive right and privilege to embody and develop her intellectual property. ${ }^{36}$ These bodies of law also recognize unauthorized international importation of such objects as a variety of infringement. ${ }^{37}$ Although these rights too are qualified by exhaustion and "first sale" doctrines, which among other things allow people who purchase such objects from the relevant intellectual property owners to resell the objects second-hand, ${ }^{38}$ we can identify an

${ }^{34}$ See, e.g., McClain v. Ortmayer, 141 U.S. 419, 423-24 (1891).

${ }^{35}$ See, e.g., Warner-Jenkinson Co. v. Hilton Davis Chem. Co., 520 U.S. 17 (1997) (explaining patent law's "doctrine of equivalents").

${ }^{36}$ See, e.g., 17 U.S.C. § 106(3); 35 U.S.C. § 271(a), (g); El Greco Leather Prods. Co. v. Shoe World, Inc., 806 F.2d 392, 396 (2d Cir. 1986).

37 See, e.g., 15 U.S.C. § 1124; 17 U.S.C. § 601(a); 19 U.S.C. § 1526; 35 U.S.C. § 271(a), (g).

38 See, e.g., 17 U.S.C. § 109; Bauer \& Cie v. O’Donnell, 229 U.S. 1 (1913); 553 U.S. 617, 625-28 (2008); Sebastian Int'l, Inc., v. Longs Drug Stores Corp., 53 F.3d 1073, 1074 (9th Cir. 1995). 
excluding privilege to distribute embodiments of intellectual property as one of the standard incidents of full intellectual property ownership. ${ }^{39}$

Intellectual property owners also have disposition rights over the intellectual things themselves. As in the context of physical property, whose owners can transfer their ownership in part (for example through leases) or in whole (through full title transfers), intellectual property owners also have various powers to dispose of their intellectual property partially (through licenses) or completely (through assignments). Intellectual property licenses and assignments are governed by various doctrines not relevant here. What they have in common as Hohfeldian powers is that they alter the entitlements that were established earlier by the first owner's ownership and subsequent developments. So through her powers to license and assign what she owns, an owner of intellectual property can transfer away any of her entitlements to it. This power is located solely in the owner herself, at least initially, and generally cannot be exercised by anyone else against her will. Private persons clearly cannot make use of others' intellectual property legally permissible, and, although the issue is murky, it is possible that not even the government can do that without compensating the owner. ${ }^{40}$ To the extent that an intellectual property owner's claim-rights and other entitlements cannot be diminished by others, we can identify a variety of Hohfeldian

${ }^{39}$ This distribution incident includes copyright law's exclusive rights to publicly perform and display specified category of copyrightable works, such as plays, songs, movies, and visual artwork. See 17 U.S.C. § 106(4)-(6).

${ }^{40}$ Compare Ruckleshaus v. Monsanto Co., 467 U.S. 986, 1013-14 (1984) (holding that the federal government's disclosure of a trade secret can in certain instances constitute a taking under the Fifth Amendment of the U.S. Constitution), with Zoltek Corp. v. United States, 442 F.3d 1345, 1353 (Fed. Cir. 2006) (holding that the federal government's taking of a license to use a patent is subject to scrutiny under statutory provisions, but not the Fifth Amendment). 
immunities from expropriation ${ }^{41}$ as together constituting a final standard incident of intellectual property ownership. But I will not pursue that project here.

In sum, American law suggests that intellectual property ownership is made up of five standard incidents:

1. An excluding privilege to embody the intellectual property.

2. An excluding privilege to develop the intellectual property.

3. An excluding privilege to distribute embodiments of the intellectual property.

4. Powers to license and assign the intellectual property.

5. Immunities from expropriation of the intellectual property.

This portrait of intellectual property ownership does not imply that any intellectual property owner worthy of that description possesses each of these standard incidents. Rather, in the same spirit as Honoré, I put forward these standard incidents to indicate what an idealized form of full ownership of an intellectual thing might look like, using the intellectual property laws that presently exist as inspiration.

Now that we have examined the entitlements that ownership of intellectual property entails as well as the kinds of intellectual things that can be privately owned as intellectual property, we have enough of an understanding of the concept of intellectual property ownership to begin inquiring into its possible justifications. But before we move on to that inquiry, it is worth taking

\footnotetext{
${ }^{41}$ According to Hohfeld's analysis, for any normative relation $X$ that holds between $A$ and some other person, $A$ has an immunity as against $B$ with respect to $X$ if and only if $B$ has no power to change $X$. See HoHFELD, supra note 7, at 60. The phrase "immunity from expropriation" originates in Honorés analysis of the standard incidents of ownership. See Honoré, supra note 18, at 119.
} 
one final moment to prepare ourselves by considering what it means to justify intellectual property ownership. This dissertation will consider two different types of potential justification for intellectual property ownership, which are also on display in discussions about physical property's justifications. The first type, which I will call a natural rights-type justification, seeks to establish that someone meeting certain requirements would be entitled to the standard incidents of intellectual property ownership (or at least some of them) regardless of what the applicable legal institutions and social conventions had to say about the matter. In the next two chapters, I will examine first John Locke's and then Immanuel Kant's natural rights-type justifications of physical property ownership, as well as their scattered comments on intellectual property ownership. The second type of justification, which I will refer to as the social convention-type, is characteristically grounded in considerations about the common good rather than individual entitlement. In Chapter 4, I will take up social convention-type justifications of property ownership, famously advanced by Jeremy Bentham and his utilitarian successors, but also by nonutilitarians like Aristotle.

My ultimate conclusion is that justifying intellectual property ownership in full requires a social convention-type justification. Natural rights-type justifications do support a few specific aspects of our intellectual property laws, but these are relatively few in number and modest in scope. Aside from this particular conclusion, however, I want to establish that intellectual property ownership affects our interests in a variety of important ways and, consequently, that no account of intellectual property ownership that attends to only one sort of affected interest is likely to be a convincing one. The word "interest" has several possible meanings in philosophical and everyday discussions, so I should say what I am taking it to mean here. Sometimes "interest" refers to a 
subjective passion or curiosity, as when we say that a person happens to take an interest in some esoteric hobby or field of study. More technically, interests are occasionally held to be aspects of a person's well-being, which can be understood in more subjective or objective terms. I will use the word in its more objective sense, but without insisting that all interests concern well-being. That is, when I say that someone has an interest in $X$, I mean to say that she has good reason to care about $X$ as it relates to herself, or to engage in $X$-type actions, or to pursue what leads to $X$, depending on the case. ${ }^{42}$ Social convention-type justifications of intellectual property ownership typically draw attention to interests that are shared widely throughout society, while different natural rights-type justifications draw attention to different interests of intellectual property owners specifically. As I argue in what follows, intellectual property ownership is justified not by any single sort of interest on its own, but by multiple, distinguishable interests of the various affected parties. In this respect, my account of intellectual property ownership's justifications is a pluralist one.

\footnotetext{
${ }^{42}$ Of course, what we have good reason to care about often depends on our more subjective features, like our personal tastes, but there are also things that we all have good reason to care about whether we happen to care about them or not, such as having an adequate supply of clean drinking water.
} 


\section{NATURAL RIGHTS I:}

\section{INTERESTS IN MATERIAL GAIN}

$[\mathrm{P}]$ roperty I have nowhere found more clearly explained, than in a book intitled, "Two Treatises of Government."

$$
\text { - John Locke }{ }^{1}
$$

Locke makes many insightful claims in his justification of property rights in the Second Treatise, but it would be a stretch to call his discussion clear. That may actually be the only point on which all Locke commentators agree. They have otherwise used his relatively compact discussion in the Two Treatises of Government to support widely diverging theories of physical property rights. Some amount of divergence is understandable given Locke's writing, which contrary to his own opinion really is not a model of clarity. He freely and repeatedly uses what can seem like metaphors (such as the image of mixing labor with physical objects) without disclosing any non-literalist intentions. He also appears to qualify his defense of private ownership by means of potentially significant conditions (such as the so-called proviso that requires acts of private appropriation to leave "enough, and as good" for others' use) without fully revealing their desired force. And, though it is no failing of Locke's, his outdated English hardly helps matters. Whatever the explanation, someone looking at past scholarly interpretations of Locke's property theory can

\footnotetext{
${ }^{1}$ Letter from John Locke to Richard King (Aug. 25, 1703), in 10 The Works of JoHn LOCKE, In Ten Volumes 305, 308 (London, J. Johnson et al. 1801). I first came across this line in Peter Laslett, Introduction to JoHN LoCKE, Two Treatises of Government 3, 3 (Peter Laslett ed., Cambridge Univ. Press 1988) (1689).
} 
find just about everything-from a defense of extremely strong and broad property rights ${ }^{2}$ to a defense of common ownership of all possessions. ${ }^{3}$

It is therefore well worth our while to look closely at Locke's account of physical property before turning to its implications for intellectual property. The interpretation I will develop in this chapter falls someplace between the extremes-supporting private property rights whose force does not depend on social agreement or convention, but not as broad a set of property rights as we find in American positive law. Locke's argument, as I understand it, is thus more modest than today's reader might expect, but when compared to the property theorists who preceded him, Locke's argument proves not so modest after all. And whatever lingering disappointment that modern audiences might feel because Locke's argument does not go further is mitigated by the fact that interpreters who have sought significantly more ambitious arguments have often judged Locke's efforts completely unsuccessful. ${ }^{4}$ The interpretation that I advocate, by contrast, accounts well for the interests we all have in obtaining material benefits through our labors. It does not, however, furnish a natural rights-type justification for very many cases of intellectual property ownership. It justifies only a fairly narrow right that overlaps with parts of our trademark doctrine, though in my view this is no embarrassment for Locke's theory.

2 See C.B. Macpherson, The Political Theory of Possessive Individualism: Hobbes to Locke 199 (1962).

${ }^{3}$ See James Tully, A Discourse on Property: John Locke AND His AdVERSARIES 164-65 (1980).

${ }^{4}$ See, e.g., JEREMY WALdRon, The Right to PRIVATE Property 252 (1988) (“[Locke] gave two arguments, and both were very weak."). 


\subsection{LOCKEAN Property, THE “MEDDLE” WAY}

Locke's discussion of private property begins with the claim that God "has given the Earth to the Children of Men, given it to Mankind in common." ${ }^{5}$ By Locke's time, this point of departure was familiar, and the history of the common ownership premise helps to reveal what it meant to Locke. Hugo Grotius had proceeded from some version of the premise to an account of private ownership grounded in mutual agreement. ${ }^{6}$ His efforts garnered criticism from Robert Filmer, an apologist for divine right monarchy and Locke's ideological adversary, ${ }^{7}$ who dismissed the idea that resources were commonly owned in the state of nature for two reasons: First, if the earth's resources were initially owned in common by the law of nature and yet universal consent could nevertheless forbid humanity from treating those resources as common property, the law of nature would be absurdly "changeable" and "contrary to itself" in first prescribing and then proscribing common ownership. Second, universal consent could never be procured in the way Grotius's view seems to require. ${ }^{8}$ As others have pointed out, Filmer's first concern is a weak one, for it depends on the assumption that natural law would be violated by consensual transfer of any rights and obligations. ${ }^{9}$ This assumption receives no defense by Filmer or anyone else for that

${ }^{5}$ LOCKE, supra note 1 , bk. $2, \S 25$, at 286.

${ }^{6}$ See Hugo Grotius, De Juri Belli ac Pacis: Libri Tres bk. 2, ch. 2, § 2, at 186-90 (Francis W. Kelsey trans., Clarendon Press 1925) (1646).

${ }^{7}$ Peter Laslett makes the case for reading Locke's property discussion as a response to Filmer in the notes accompanying that discussion in his critical edition of Locke's Second Treatise. See LOCKE, supra note 1, bk. 2, § 25, at 285-86.

${ }^{8}$ See Robert Filmer, OBSERVATIONS CONCERNing THE ORIGINALl OF GOVERNMENT (1652), reprinted in Patriarcha AND Other Writings 184, 234 (Johann P. Sommerville ed., Cambridge Univ. Press 1991).

${ }^{9}$ See, e.g., WALDRON, supra note 4, at 151. 
matter, which is not surprising given the assumption's implausible implication that one cannot making a binding promise to perform actions not otherwise required by the natural law. But one virtue of Filmer's first objection is that it brings attention to the ambiguity in the Grotian common ownership premise: What exactly does common ownership amount to in the state of nature?

Modern property law recognizes a form of common ownership of land, tenancy-incommon, which endows the co-owners or "co-tenants" with a Hohfeldian privilege to access any part of the parcel and a claim-right not to be excluded or "ousted" by the other co-tenants. ${ }^{10}$ Common ownership in the state of nature could be like that. Indeed, Samuel von Pufendorf seems to have thought that Grotius's critics wrongly held some such conception of common ownership in mind when they leveled their critiques. ${ }^{11}$ Pufendorf sought to clarify matters by distinguishing between "negative" and "positive communion": in a state of negative communion, specific resources do not yet belong to anybody; in a state of positive communion, specific resources belong "to many Persons together . . in the very same manner" that private property belongs to one person alone. ${ }^{12}$ Now, if positive communion, perhaps along the lines of modern property law's tenancy-incommon, were indeed the starting position in a Grotian state of nature, Filmer's second objection to Grotius would have real force. Actual universal consent cannot realistically be procured because privatization of the commons would change everyone's normative circumstances radically, and perhaps not for the better. Before the agreement, each person has a claim-right not to be excluded

${ }^{10}$ See 20 AM. JuR. 2D Cotenancy and Joint Ownership §§ 41, 49 (2011).

${ }^{11}$ SAmuel von Pufendorf, Of the Law of NAture And NATions: Eight Books bk. 4, ch. 4, § 2, at 363 (Basil Kennett \& George Carew trans., London, J. Walthoe et al. 1729) (1672).

${ }^{12}$ Id. bk. 4, ch. $4, \S 2$, at 362 . 
from any part of the commons. Afterward, most such claim-rights give way to duties not to use what one does not own, which in short order will limit everyone's access to the overwhelming majority of the world's resources. Even a single hold-out would stymie the privatization of the commons because that person would have a claim on all resources just as strong as everyone else's. ${ }^{13}$ On Pufendorf's understanding of common ownership in the state of nature, however, individuals never had any such claim-right to make use of the world's resources; they simply were permitted to do so if they could. For, according to Pufendorf, the world's resources were subject to a negative communion before social agreements instituted rules of private property: "all things lay free to any that would use them, and did not belong to one more than to another." ${ }^{14}$

But Filmer's second objection, concerning the improbability of actual agreement, is not so easily overcome. Even in the negative communion Pufendorf imagines, individuals necessarily lose something valuable in the shift to private ownership. Specifically, they lose their privileges to use all resources within their reach, at least for the resources that are now (purportedly) the private property of somebody else. And of course a person who refused to give up that state-of-nature freedom would not be bound by others' private property compact on a wholly consent-based view

${ }^{13}$ And Filmer raised exactly this objection against Grotius:

Certainly it was a rare felicity that all the men in the world at one instant of time should agree together in one mind to change the natural community of all things into private dominion. For without such an unanimous consent it was not possible for community to be altered. For if but one man in the world had dissented, the alteration had been unjust, because that man by the law of nature had a right to the common use of all things in the world, so that to have given a property of any one thing to any other had been to have robbed him of his right to the common use of things.

FILMER, supra note 8, at 234.

${ }^{14}$ PUfENDORF, supra note 11 , bk. 4 , ch. $4, \S 5$, at 366 . 
of property. Since no one wants to entertain the possibility that figuring out who is bound by property laws must be done on a case-by-case basis, the negative/positive communion distinction does not help consent-based views with Filmer's second concern.

Filmer denied common ownership, claiming that God had given Adam exclusive private ownership over all the world's resources and plenary authority to distribute them as he saw fit. Locke himself retains a sort of common ownership premise, but he avoids the problem that Grotius and Pufendorf face by insisting against them that private property rights can arise even without "any express Compact of all the Commoners." ${ }^{15}$ Locke agrees that no one has any special claim-right to the exclusive use of particular resources "in their natural state," ${ }^{16}$ implying that generally everyone has a privilege to use any unclaimed natural resource. ${ }^{17}$ But he parts ways with Grotius and Pufendorf over their view that consent is the only way that this use-privilege is lost. On Locke's view, “the great Foundation of Property” derives from each man's ability to transform, through labor, natural resources for material gain or, as he says, for "the Support or Comfort of his being." 18 Thus unlike the natural commons Grotius and Pufendorf imagined, in Locke's commons everyone's use-privileges are qualified by a Hohfeldian liability: for any unclaimed resource, each

${ }^{15}$ Locke, supra note 1 , bk. 2, § 25, at 286; see also id. bk. 2, § 28, at 288 ("If such a consent as that [i.e. "the consent of all Mankind"] was necessary, Man had starved, notwithstanding the Plenty God had given him.").

${ }^{16} I d$. bk. $2, \S 26$, at 286 .

17 This implication follows from the fact that privileges are "jural correlatives" of Hohfeld's inelegantly named "no-

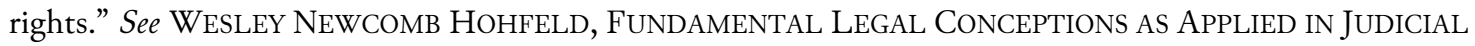
REASONING 38-39 (Walter Wheeler Cook ed., 1920). As we shall see, however, Locke believes that the general privilege to use any resource is qualified by (inter alia) others' superior claim on resources necessary for survival. See infra p. 12.

${ }^{18}$ LoCKE, supra note 1 , bk. $2, \S 44$, at 298-99. 
person has a Hohfeldian power ${ }^{19}$ to labor upon it and thereby replace others' moral privilege to use it with a duty not to do so. ${ }^{20}$ But how is it that labor has this impressive ability to transform goods from commonly to privately owned? Locke articulates his position in a variety of ways, some more felicitous than others.

In what may be the most often quoted section of the argument, Locke seems to justify an individual's property rights in tangible resources by invoking that individual's preexisting "Property in his own Person" and "Labour." "Whatsoever [the laborer] removes out of the State that Nature hath provided, and left it in, he hath mixed his Labour with, and joyned to it something that is his own, and thereby makes it his Property." ${ }^{22}$ So it seems the way that mixing labor with a natural resource transforms it (from something available for anyone's use to something others now have a duty not to use) has something to do with the fact that the resource now has within it a substance that belongs to the laborer-namely, his labor. ${ }^{23}$ In the very next section, though, Locke abandons this mixture/joining imagery, instead speaking of labor less as substance and more as activity: "The labour that was mine, removing [natural resources] out of that common state they were in, hath

${ }^{19}$ For Hohfeld, to say that $A$ has a power over $B$ with respect to normative relation $X$ (e.g. a claim-right or duty) is just to say that $A$ can act in such a way that alters the normative relation $X$ between $B$ and someone else. And to say that $A$ has a power over $B$ with respect to $X$ is just to say $B$ has a liability to $A$ with respect to $X$ because powers and liabilities are jural correlatives. See HoHFELD, supra note 17, at 50-51.

${ }^{20}$ John Simmons also emphasizes this moral power in his description of Locke's state of nature. See A. JOHN SiMMONS, THE LOCKEAN THEORY OF RigHTS 72 (1992).

${ }^{21}$ LOCKE, supra note 1 , bk. 2 , § 27 , at 287, 288;

${ }^{22}$ Id. bk. $2, \S 27$, at 288 .

${ }^{23}$ See id. bk. 2, § 27, at 287-88; id. bk. 2, § 32, at 291 ("He that ... subdued, tilled and sowed any part of [the Earth] thereby annexed to it something that was his Property, which another had no Title to, nor could without injury take from him"). 
fixed my Property in them."24 Later, Locke varies his phrasing yet again: "he that so employed his Pains about any of the spontaneous Products of Nature, as any way to alter them, from the state which Nature put them in, by placing any of his Labour on them, did thereby acquire a Propriety in them." 25

Because of this loose use of language it is odd as a matter of interpretation to assume, as Robert Nozick and Jeremy Waldron do, that Locke's mixture/joining imagery does its intended philosophical work only if taken quite literally. They are right to express doubt about the proposition that labor can be combined with physical objects as though it were a substance, perhaps like water can be mixed with flour, and they are also right to resist the idea that mixing something one owns with something one does not own establishes ownership of the resulting mixture. ${ }^{26}$ But they are wrong to suggest that Locke is committed to either the spooky metaphysics or the implausible moral claim. In saying that we mix labor with natural resources, there is no reason to believe he had anything so literal in mind. After all, Locke elsewhere spoke of mixtures of ideas and dance moves. ${ }^{27}$ Rather than concluding that Locke's labor-mixing passage

${ }^{24} I d$. bk. $2, \S 28$, at 289 .

${ }^{25}$ Id. bk. 2 , § 37 , at 294-95.

${ }^{26}$ See Robert Nozick, ANARChy, State, AND Utopia 174-75 (1974); Jeremy Waldron, Two Worries About Mixing One's Labour, 33 PHIL. Q. 37, 39 (1983) (“[T] he argument based on mixing labour . . is defective to the point of incoherence ....”). Much earlier, David Hume voiced his own concerns about the labor-mixing imagery and preferred to view labor as the activity of altering natural resources. See DAVID Hume, A TREATISE OF Human Nature bk. 3, pt. II, § 3, at 505 n.1 (L.A. Selby-Bigge \& P.H. Nidditch eds., Oxford Univ. Press 2d ed. 1978) (1739-1740) ("We cannot be said to join our labour to any thing but in a figurative sense.").

${ }^{27}$ See John Locke, An Essay ConCerning Human Understanding bk. 2, ch. 33, § 16, at 399 (Peter H. Nidditch ed., 1975) (1690) (relating an account "of a young Gentleman, who having learnt to Dance, and that to great Perfection, there happened to stand an old Trunk in the Room where he learnt. The Idea of this remarkable piece of bousebold stuff had so mixed itself with the turns and steps of all his Dances, that though in that Chamber he could Dance 
should be interpreted literally despite the problems such an interpretation generates, we ought consider the possibility that he meant something else. ${ }^{28}$

Fortunately there is a way of understanding Lockean labor that makes sense of the labormixing passage and the other key parts of Locke's discussion. For Locke, labor is a certain sort of deliberate resource use for the sake of material gain. More specifically, labor is intentional activity aimed at using resources for survival and comfort. ${ }^{29}$ Human beings, on Locke's account, have overwhelmingly strong reasons to put the earth's resources to good use. ${ }^{30}$ In part, we owe such behavior to God because of His commands to enjoy the world He created, but we also have independent reason to use resources to improve our own well-being. ${ }^{31}$ We should "enjoy" and "make use of" nature's gifts "to any advantage of life" 32 and draw from them "the greatest

excellently well, yet it was only whilst that Trunk was there, nor could he perform well in any other place, unless that, or some such other Trunk had its due position in the Room" (emphasis added)).

${ }^{28}$ On this point, I follow StePHen BuCKLe, Natural LAW AND the THeOry of Property 152, 174 (1991); Simmons, supra note 20, at 273; and T.M. Scanlon, Natural Wrongs and Institutional Rights I: Property 12 (Feb. 1987) (unpublished manuscript) (on file with author). My understanding of Locke's argument owes a great deal to their accounts.

${ }^{29}$ See, e.g., SimMONS, supra note 20, at 273.

${ }^{30}$ This view is also found in the First Treatise, where Locke describes the "Right to the use of the Creatures" as "founded Originally in the Right a Man has to subsist and enjoy the conveniences of Life." LOCKE, supra note 1, bk. 1, $\S 97$, at 212. Locke's primary purpose in that part of the First Treatise, however, is to challenge Filmer's theory that a royal line of succession began with Adam and bestowed sovereignty over all his children to one of them in particular. See id. bk. $1, \S 84$, at 204.

${ }^{31}$ See id. bk. 2, § 32, at 291 ("God, when he gave the World in common to all Mankind, commanded Man also to labour, and the penury of his [i.e. Man's] Condition required it of him. God and his Reason commanded him to subdue the Earth, i.e. improve it for the benefit of Life, and therein lay out something upon it that was his own, his labour."); cf. id. bk. 2, § 26, at 286 ("God, who hath given the World to Men in common, hath also given them reason to make use of it to the best advantage of Life, and convenience. The Earth, and all that is therein, is given to Men for the Support and Comfort of their being.").

32 Id. bk. 2, § 31, at 290 (emphasis omitted). 
Conveniences of Life" that we are capable of. ${ }^{33}$ When an individual in Locke's state of nature labors, she is using resources in the way they ought to be used. To say that an individual mixes her labor with a resource is merely to say that she is using that resource in order to gain what is necessary or convenient for life. ${ }^{34}$ The fact that a laborer is now using this resource distinguishes it from the other, still-common resources and removes it "from the common state Nature placed it in. ${ }^{35}$ For Locke, this distinguishing characteristic — the fact that someone has started using the resource for material gain—is morally significant. In certain conditions, he claims, laboring gives the laborer $L$ a claim-right against another person $N$ such that $N$ may not to make certain unauthorized uses of the resources $R$ that figure in L's labor. He gives a pair of reasons to support this claim.

First, some of $N$ s unauthorized uses of $R$ will impose a hardship on $L$. If $L$ cultivates some land for the sake of producing food, and $N$ swoops in and takes over some of the land $L$ was working upon, $N$ s interference with $L$ 's labor injures $L$ : "He that in Obedience to this Command of God, subdued, tilled and sowed any part of [the earth], thereby annexed to it something that was his Property, which another ... could [not] without injury take from him." ${ }^{36}$ But note that Locke does not claim here that every unauthorized use of $R$ by $N$ would wrong $L$. He focuses on

${ }^{33}$ Id. bk. 2, § 34, at 291 .

${ }^{34}$ See SimmONS, supra note 20, at 273-74.

${ }^{35}$ LocKE, supra note 1, bk. 2, § 27, at 288; accord id. bk. 2, § 28, at 288 ("That labour put a distinction between them and common."); id. bk. 2, § 37, at 294-95; cf. A. John Simmons, Makers' Rights, 2 J. ETHICs 197, 210 (1998), reprinted in JUSTIFICATION AND LEGITIMACY 249, 262 (2001).

${ }^{36}$ LOCKE, supra note 1, bk. 2, § 32, at 291. 
the case in which $N$ s unauthorized use takes the improved version of $R$ away from $L$ and thereby causes injury. Likewise, he limits $L$ 's right against $N$ to situations in which $L$ is actually putting $R$ to use. "Nothing," Locke insists, “was made by God for Man to spoil or destroy” for no purpose. ${ }^{37}$ According to Locke, this prohibition of pointless waste is the principal limit on property rights in the state of nature. And any unauthorized use of another's possessions that does not actually interfere with that person's constructive laboring is not wrongful. For $L$ has "no Right" to his resources $R$ "farther than bis Use called for any of them, and they might serve to afford him Conveniences of Life." ${ }^{38}$ Locke does not even appear to relax this limit where $R$ would not exist were it not for $L$ 's labors. If $L$ goes to the trouble of growing fruit on unclaimed land but allows the fruit to perish, the land is "still to be looked on as Waste, and might be the Possession of any other"; ${ }^{39}$ presumably any still-living vegetation comes with it. In places, Locke further claims that waste actually wrongs other people. ${ }^{40}$ This claim is distinct from the claim that using what is being wasted by somebody else is entirely permissible, and seems to require a separate defense that Locke nowhere explicitly provides. ${ }^{41}$ In any case, where $L$ is not wasting $R$ but using $R$ to gain what is a

${ }^{37}$ Id. bk. $2, \S 31$, at 290 .

${ }^{38}$ Id. bk. $2, \S 37$, at 295 .

${ }^{39}$ Id. bk. $2, \S 38$, at 295 .

${ }^{40}$ Locke describes waste as robbery and as an injury to others. Id. bk. 2 , § 46, at 300.

${ }^{41}$ To my mind, it is harder for Locke to explain the impermissibility of waste in a world of abundance than the permissibility of using what is being wasted. Perhaps he thinks waste wrongs others because taking possession of a common resource, for example by enclosing land with a fence, communicates to others that they may no longer use it. Cf. id. bk. 2, § 51, at 302 (“[W] hat Portion a Man carved to himself, was easily seen.”). Since taking possession signals to others that their use-privileges have been taken away, the possession-taker must make good on his signal or else he will be "dishonest," as Locke says. Id. bk. 2 , $\S \S 46,51$, at 300, 302. But this interpretation would account for only some of the language that Locke uses to condemn waste. 
necessity or a convenience for him, and where, further, $N$ s use would interfere with $L$ 's use of $R$, the fact that $N$ s use would harm $L$ is a good reason for $N$ not to use $R$ in that way. In one important but frequently overlooked passage, Locke expresses this point using language quite like the notion of interference: a person "ought not to meddle with what was already improved by another's Labour." 42

Second, $N$ sometimes has no good reason for accessing $R$. Early on, Locke rules out the possibility that $L$ has a duty to labor on $N$ s behalf, saying that $N$ has "no right to" "the benefit of another's Pains. ${ }^{\not 33}$ Moreover, Locke observes that $N$ is not harmed by the duty not to interfere with $L$ 's labor provided that $N$ retains the ability to labor as he pleases on enough resources that are as good as $R$ : "For he that leaves as much as another can make use of, does as good as take nothing at all." ${ }^{44}$ In the secondary literature, there is some controversy about whether this "enough and as good" condition, which Nozick dubbed "Locke’s proviso," 45 should be seen as a necessary condition or as a sufficient condition for duties to refrain from using others' property. ${ }^{46}$ There are good reasons for thinking that it is necessary condition within the particular argument that Locke

${ }^{42}$ Id. bk. 2, § 34, at 291 (emphasis added).

${ }^{43} I d$. bk. 2, § 34, at 291. On its face, this passage is consistent with another interpretation, namely that $X$ has no privilege (in Hohfeld's sense) to benefit from $L$ 's pains. That interpretation would certainly rule out $X$ 's unauthorized use of $R$, but it is inconsistent with Locke's insistence on a privilege to use what is being wasted.

${ }^{44} I d$. bk. 2, § 33, at 291; see also id. bk. 2, §§ 27, 34-36, at 288, 291-93.

${ }^{45}$ NozicK, supra note 26 , at 175 ; see also id. at 178-82.

${ }^{46}$ Nozick and Simmons are among those inclined to treat the proviso as a necessary condition, while Judith Jarvis Thomson and Waldron favor interpreting it as nothing more than a sufficient condition. Compare NozICK, supra note 26, at 178, and Simmons, supra note 20, at 294, with Judith Jarvis Thomson, Property Acquisition, 73 J. PHIL. 664, 666 (1976), and Jeremy Waldron, Enough and As Good Left for Others, 29 PHIL. Q. 319, 321 (1979). 
is advancing in the Second Treatise. That seems to me the most straightforward reading of his claim that labor grounds exclusive use rights "at least where there is enough, and as good left in common for others. ${ }^{\not 47}$ The proviso cannot be sufficient for property duties because, as we have seen, there is also the necessary condition that the property owner must not be letting the property spoil pointlessly. But we need not understand the proviso as a necessary condition for justifying private property rights in any conceivable situation whatever. If, as Waldron imagines, ${ }^{48}$ we enter a world with no preexisting social agreements and a keen scarcity of essential resources, Locke need not reject the possibility of us being able to make some sort of justified exclusive use of those resources. He must, however, acknowledge that in such a setting any justification for using resources to the exclusion of others would have to proceed differently than the account he has offered. He does not discuss the issue, however, because he is quite confident that original acquisition began in a world that as a matter of fact did contain plenty of resources for humanity's survival and convenience. ${ }^{49}$ If that assumption were false, Locke would have to abandon his argument. But as long as he is

${ }^{47}$ LOCKE, supra note 1 , bk. $2, \S 27$, at 288 (emphasis added).

${ }^{48}$ Waldron, supra note 46 , at 325.

${ }^{49}$ Locke is confident for at least two reasons: First, the foolishness of accumulating more than one could make use of before it spoiled would limit private holdings considerably. See LOCKE, supra note 1, bk. 2, § 46, at 300. Second, because labor and its consequences are responsible for the vast majority of the usefulness or "value" of resources, a little bit of natural resources goes a long way toward furnishing the necessities and conveniences of life, and it takes widespread agreement to adopt an arbitrary system of value, such as currency, with the potential to generate conditions that incentivize privatizing enough resources that "enough and as good" no longer remain. See id. bk. 2, §§ 43-50, at 298-302. 
assuming plenitude, he need not take a position on whether (or how) appropriation would be permissible in a state of nature where resources are scarce. ${ }^{50}$

Locke thus argues that rights to use resources exclusively arise in the state of nature whenever (1) a laborer is seeking to benefit from the resources and others' use of the resources would threaten the laborer's success and (2) the laborer's exclusive use of the resources does not constrain everyone else's ability to labor on other resources of sufficient quantity and comparable quality. When both conditions are met, others have a duty not to meddle with or interfere with the laborer's actions. If, however, either condition is not satisfied, Locke's main argument does not condemn others' use of the resources the laborer is using.

It should be clear that this argument for a variety of natural property rights falls quite short of justifying the rights that appear in contemporary property law. Other writers have pointed out several ways that a right against interference with labor differs from what we think of as property ownership today. Stephen Buckle notes that Locke's property right does not give the right-holder absolute control over the disposition or use of the thing she owns even to the extent of permitting the thing's pointless destruction. ${ }^{51}$ Simmons makes the related point that in contemporary legal

\footnotetext{
${ }^{50}$ Nor is Locke prohibited from endorsing more complex principles of justice in a civil society marked by inequality. He is already on the record stating that "Charity gives every Man a Title to so much out of another's Plenty, as will keep him from extream want, where he has no means to subsist otherwise" and that "Man can no more justly make use of another's necessity, to force him to become his Vassal, by with-holding that Relief, God requires him to afford to the wants of his Brother." Id. bk. $1, \S 42$, at 170. This demand of charity could perhaps be expanded or supplemented in ways consistent with Locke's commitments. To be sure, Locke explicitly says that the agreement to treat precious metals as valuable constitutes an agreement "to disproportionate and unequal Possession of the Earth," see id. bk. $2, \S 50$, at 302, but it is not at all clear what this statement means, why it is credible, whether Locke approves of the putative agreement, or how immutable the agreement remains in civil society. In any event, I will not explore this idea further here.

${ }^{51}$ BuCKLE, supra note 27, at 181.
} 
systems, owners' exclusive rights are not restricted to situations where they are actually using their property. ${ }^{52}$ Finally, T.M. Scanlon emphasizes the difference between Lockean and ordinary understandings of the transferability of property, pointing out that on Locke's labor theory the transferee does not obtain a claim-right against interference by third parties going forward unless she makes use of the transferred object to obtain the necessities and conveniences of life..$^{53}$ Property laws, perhaps alongside other social conventions, have relaxed Locke's waste limitation and made transfer of property subject to fewer such contingencies.

But this development is no surprise to Locke, who clearly envisioned social convention and agreement playing an important role in refining the basic natural right against meddling with labor. Civil societies, he says, "have made and multiplied positive Laws to determine Property," although those laws often still implement the "original Law of Nature for the beginning of Property, in what was before common," such as common stocks of fish in the ocean which may be kept by anyone who catches them. ${ }^{54}$ Elsewhere in his discussion of property, he describes communities as enacting laws to "regulate[] the Properties of the private Men of their Society, and so, by Compact and Agreement, settl[ing] the Property which Labour and Industry began., ${ }^{55}$ This regulation of property

52 SimMONS, supra note 20, at 277. A good example of Simmons's observation can be found in modern trespass law, which generally prohibits entering onto someone's land even if that entry does not interfere with any use that the landowner is making of her land. See, e.g., Jacque v. Steenberg Homes, Inc., 563 N.W.2d 154 (Wis. 1997).

${ }^{53}$ Scanlon, supra note 27, at 25-27; accord SimMONS, supra note 20, at 137. Locke does, of course, categorize the gratuitous giving away of resources and trade as use rather than waste on the transferor's part. See LOCKE, supra note 1, bk. $2, \S 46$, at 300 . But that categorization does not entail that the transferee gains exclusive rights apart from beginning to put the resources to good use.

${ }^{54}$ LocKe, supra note 1, bk. 2, § 30, at 289; see also id. bk. 2, § 50, 302 ("For in Governments the Laws regulate the right of property, and the possession of land is determined by positive constitutions.").

${ }^{55}$ Id. bk. $2, \S 45$, at 299 . 
is precipitated by or at least follows conventions that introduced money as a means of transferring and accumulating value. ${ }^{56}$ Locke does not give a comprehensive description of the ways that positive law "settles" property rights, but he does hint that one of the major ways it does so is by making property rights more secure. This rationale is at the heart of Locke's theory for why people enter into civil society. Because an individual in the state of nature would know that "enjoyment of the property he has in this state is very unsafe, very unsecure," he consequently agrees "to joyn in Society with others ... for the mutual Preservation of their Lives, Liberties and Estates." ${ }^{57}$ Civilized society is attractive in large part because it, unlike the state of nature, offers a means for resolving disputes by appeal to an impartial authority. ${ }^{58}$

Although Locke does not discuss the subject, civil society's ability to safeguard rights can theoretically extend beyond adjudication of disputes that have already arisen by promulgating explicit rules that clarify the rights and duties of its members and therefore make disputes less likely to arise. When Pufendorf leaned so heavily on property conventions, he did so in part because of the essential role they play in making individual rights and duties clear. ${ }^{59}$ Although

${ }^{56}$ See id. bk. 2, §§ 45-50, 299-302.

${ }^{57}$ Id. bk. 2 , § 123, at 350. It is worth noting that when Locke speaks of "Property," he is not in line with modern usage but is rather referring to "Lives, Liberties and Estates" together. Id.; accord bk. 2, §§ 87, 173, at 323, 383. Locke's usage was not unusual at the time he wrote Two Treatises. See id. bk. 2, § 27 editor's note, at 287.

${ }^{58}$ See id. bk. 2, § 21, at 282 (citing conflict resolution as "one great reason of Mens putting themselves into Society"); $i d$. bk. 2, § 124, at 350-51 (explaining that the state of nature "wants an establish'd, settled, known Law, received and allowed by common consent to be the Standard of Right and Wrong, and the common measure to decide all Controversies between them"); $c f . i d$. bk. 2, § 19, at 280 (defining the state of nature by reference to its lack of "a common Superior on Earth, with Authority to judge between" individual disputants).

${ }^{59}$ See PufENDORF, supra note 11, bk. 4, ch. 4, § 9, at 372 (“[N]either could others know what any Person intended to keep for his own ....”); id. bk. 4, ch. 4, § 10, at 372 (“[T] here was need of some human Act and Agreement, that others might know what belong'd to every distinct Person ...."). 
Pufendorf overstated the extent to which conventions are absolutely necessary for normative guidance, he was right to observe their usefulness in making violations of property rights less likely. Locke is perhaps overly optimistic in suggesting that his labor-based account of property would leave "no room for Controversie about the Title, nor for Incroachment on the Rights of others" because "what Portion a Man carved to himself, was easily seen." ${ }^{, 60}$ Surely such disputes are easy to imagine even among people who honestly attempt to respect the rights of others. Consider the classic example of the acorn-gatherer. ${ }^{61}$ A pile of acorns sitting under an oak tree indeed appears to be something only human intelligence would produce. (Any other nut-gathering animal would be prudent enough to hide his or her stash.) But imagine that a highly conscientious acorn-gatherer goes around naively collecting acorns that, as it turns out, were purposefully arranged under a tree to look as though they were in their natural state as part of a "Postmodernism in the State of Nature" art exhibition. (The tree, you see, is actually a maple.) Human beings would certainly make some honest mistakes about what would interfere with others' use of abundant tangible resources, even in the state of nature, and so Locke should take a modest cue from Pufendorf and allow that property conventions help to clarify the boundaries of natural rights. But I also think he should happily acknowledge that positive laws expand property rights beyond those that exist in the state of nature. And it may even be possible to give those expansions a social convention-type justification, though I will not pursue this possibility.

\footnotetext{
${ }^{60}$ LoCKE, supra note 1 , bk. 2 , § 51, at 302; see also id. bk. 2, § 31, at 290.

${ }^{61}$ See, e.g., id. bk. $2, \S 28$, at 288.
} 
Even with the large role that convention and agreement eventually play in Locke's story of the transition to civil society, the interpretation I have been advocating still preserves a significant difference between his views and those of the Continental natural lawyers who preceded him. In asserting that individuals have a natural claim-right that others not interfere with their harmless efforts to make life better for themselves, Locke parts company with his predecessors who saw mutual agreement as the only possible source of any such right. Although Grotius approvingly cited Cicero's comparison of property in the state of nature to the claiming of an open seat at a theater, he did not seem to judge that there was any more robust form of natural property rights that could extend beyond the time one was physically in possession of the object ${ }^{62}$ or beyond the resources necessary for bare subsistence. ${ }^{63}$ Pufendorf was apparently not willing to allow even that very thin sort of natural property right. ${ }^{64}$ While Grotius concluded that "whatever each had ... taken [arripuerat] for his own needs another could not take [eripere] from him except by unjust act, ${ }^{, 65}$ Pufendorf denied that it was wrong, in the absence of any agreement to the contrary, to take resources that another person had seized to sustain himself: "that one Man's seizing on a thing should be understood to exclude the Right of all others to the same thing, could not proceed but

${ }^{62}$ See Grotius, supra note 6, bk. 2, ch. 2, § 2, at 186 ("Although the theatre is a public place, yet it is correct to say that the seat which a man has taken belongs to him." (quoting CiCERO, DE FiniBUS BONORUM ET MALORUM bk. $3, \S 20$ (45 B.C.))).

${ }^{63}$ See, for example, Grotius's explanation of how the exclusive use rights that existed in the earliest state of nature were acceptable only so long as people maintained the simplest of lifestyles. Id. bk. 2, ch. 2, § 4, at 189.

\footnotetext{
${ }^{64}$ I have benefited here from Michael Zuckert's clear comparison of these two natural lawyers' views. See MICHAEL P. ZuCKERT, NATURAL RightS AND THE NEW REPUbLICANISM 251-52 (1994).

${ }^{65}$ GROTIUS, supra note 6, bk. 2, ch. 2, § 2, at 186.
} 
from mutual Agreement." ${ }^{66}$ To obtain exclusive rights to a theater seat, therefore, one had to rely on a prior agreement, even if only a tacit one, that established the possibility of gaining such rights by occupying the seat. ${ }^{67}$

Locke goes beyond Grotius and still further beyond Pufendorf in defending exclusive rights to resources outside the period of physical possession or occupation. Indeed, the difference between these writers is conspicuously on view when Locke parts ways with Grotius and Pufendorf over the point at which wild animals become private property. The latter both argue that physical possession (or infliction of a mortal wound) is required ${ }^{68}$ while Locke says that one begins a Property in a wild animal as soon as one discovers it and gives chase. ${ }^{69}$ On the noninterference interpretation, Locke's conception of beginning a property is simply exercising one's prerogative to labor, which generates a claim-right against interference by others. An intermeddler can interfere

${ }^{66}$ PUfENDORF, supra note 11, bk. 4, ch. 4, § 4, at 365; see also id. bk. 4, ch. 4, § 9, at 372 ("[T] hat [seizure or physical possession] might be capable of producing a Moral Effect, or an Obligation in others to forbear what each Man had taken for his particular, must necessarily have depended on the force of some precedent Covenant.").

${ }^{67}$ See id., bk. 4, ch. 4, § 10, at 373.

${ }^{68}$ See Grotius, supra note 6, bk. 2, ch. 8, § 3, at 296-97; PUFENDORF, supra note 11, bk. 4, ch. 6, § 10, at 392. Grotius of course generally thinks that in the state of nature seizure of something common gives one minimal exclusive rights to it, but in the passages on wild beasts he is concerned with interpreting positive law. He expressly states that the law could be changed so as to let ownership of wild animals begin at an earlier point. GROTIUs, supra note 6, bk. 2, ch. $8, \S 5$, at 297. Pufendorf too is interpreting positive law (as is Locke, for that matter), but he expressly denies that the law could permit ownership at a point before possession (or mortal wounding). See PUFENDORF, supra note 11, bk. 4, ch. 6, § 7, at 390. For a terrific overview of these sources, see Charles Donahue, Jr., Animalia Ferae Naturae: Rome, Bologna, Leyden, Oxford and Queen's County, N.Y., in STUdies in Roman LAW IN MEMORY OF A. ARTHUR SCHILLER 55-59 (Roger S. Bagnall \& William V. Harris eds., 1986).

${ }^{69}$ See LOCKE, supra note 1, bk. 2 , § 30, at 290 ("[E]ven amongst us the Hare that any one is Hunting, is thought his who pursues her during the Chase. For being a Beast that is still looked upon as common, and no Man's private Possession; whoever has imploy'd so much labour about any of that kind, as to find and pursue her, has thereby removed her from the state of Nature, wherein she was common, and hath begun a Property."). 
with a person's labor, and therefore commit a wrong, even before the laborer has gained physical possession of the labored-on resource. ${ }^{70}$ Likewise, such interference can occur after the laborer has set down the resource, at least provided that he is still using it to gain life's conveniences or necessities. And so even if our acorn-gatherer sets down his haul in order to attend to other sylvan matters, it is wrong for another person to snatch up the gathered acorns regardless of whether a common agreement exists saying so. ${ }^{71}$ Such an act would be wrong, on Locke's view, because it interferes with the acorn-gatherer's labor-specifically his use of these particular examples of an abundant resource. Thus although my interpretation of Locke's argument sees him as justifying a set of rights that falls rather short of the modern legal understanding of property ownership, in itself that fact is no argument against its accuracy as an interpretation. Locke did not need to justify a fuller collection of rights to distinguish himself from the property theorists who preceded him.

\subsection{DEFINING INTERFERENCE WITH LABOR}

According to the foregoing account, Lockean property rights prevent interference with labor. Yet saying that something interferes with something else can be a loose way of speaking. Unsolicited advice can interfere with a person's concentration or decisionmaking. A new

\footnotetext{
${ }^{70}$ Locke is sometimes criticized for being out of step with the legal authorities here. See, e.g., ARTHUR RIPSTEIN, ForCe AND FreEdom: Kant's Legal AND Political PhilosopHy 100 n.18 (2009) (“All the classic discussions reject the Lockean view."). But this criticism is too hasty. As Charles Donahue has explained, Roman law likely would have seen intentional interference with a hunter's efforts to obtain a wild animal as an actionable injury. See Donahue, supra note 68 , at $48-50$.

${ }^{71}$ See LOCKE, supra note 1, bk. 2, § 28, at 288.
} 
competitor can interfere with business plans. Skillful defensive game play can interfere with the offense's strategy. Often, but not always, labeling an act "interference" is a way of criticizing it. The task of this section is to specify a sense (or, as we shall see, senses) of interference with labor to pick out the behavior that is wrongful under Lockean principles. For the follower of Locke, it is important to be able to furnish some such analysis of the concept of interference that does not rely entirely on social practices ${ }^{72}$ because Locke himself thought it was important to provide an account of exclusive rights that do not depend on implicit or explicit social agreement for their normative force. If the only way to identify impermissible interference requires consulting a list of interfering actions that were proscribed within the social group, Locke's goal is not going to be attainable.

Arthur Ripstein has recently expressed skepticism about the possibility of articulating a coherent concept of Lockean interference. For Ripstein, either the concept of interference with another's labor amounts to nothing other than interference with her person, or it does no philosophical work of its own but rather demands independent appraisals of the laborer's and interferer's actions. ${ }^{73}$ Ripstein's concerns are prompted by cases in which it is obviously permissible to interfere with the labor of someone else-just imagine that person is trying to cut your hair without permission. ${ }^{74}$ Surely Ripstein is right that it is permissible to stop this officious barber, but that does not demonstrate any flaw in Lockean principles of noninterference. Anyone who affirms

\footnotetext{
${ }^{72}$ I will, however, be assuming that linguistic social practices are already in place because it is difficult to imagine deliberative action without language.

${ }^{73}$ RIPSTEIN, supra note 70, at 101.

${ }^{74}$ See id.
} 
rights against bodily interference and rights to engage in acts of self-defense, as Ripstein does, ${ }^{75}$ must accept the possibility that interference is permissible when it is interference with something impermissible. $^{76}$ The aggressor's right against bodily interference does not prohibit his victim from responding to his threat with force. But this truth does not imperil the right against bodily interference in any way; it simply requires that we be clear about what that right protects. So too with the Lockean right against interference with labor. Labor, like any sort of action, is bounded by "the Law of Nature,"77 and so labor that is morally objectionable for some special reason does not merit protection against interference. There is no duty to forbear interfering with labor that would violate another's right of bodily integrity, just as there is no duty, as Locke points out, not to interfere with labor that denies others what they need to survive. This particular kind of example poses no danger to Locke's argument.

But it remains true that Locke's argument requires some account of what qualifies as wrongful interference with labor. Some labor seems not to deserve protection from interference because of others' interests, even when the labor itself does not wrong them impermissibly. Suppose, for example, that I choose to read one of my philosophy papers to you. Please assume at

${ }^{75}$ See id. at 41, 177.

${ }^{76}$ Of course, we could debate the details of precisely when such interference is permissible. Ripstein understands self-defense (in the state of nature) as permissible whenever the threatened person forms a good-faith belief that he or she is under a wrongful threat, regardless of whether such is the case. See id. at 178-79. But one could entertain many different accounts, according to which self-defense would be permissible, just to name a few possibilities, only if (1) the self-defender had a true belief that she was under a wrongful threat, (2) the self-defender had a reasonable belief (whether or not true) that she was under a wrongful threat, or (3) the self-defender truly was under a wrongful threat (whether or not she believed this). There is room for similar refinement of an account of permissible interference with labor, but I will not take a position on any of these details here.

${ }^{77}$ LOCKE, supra note 1, bk. 2, § 4, at 269; see also Scanlon, supra note 27, at 13. 
least for argument's sake that my doing so is not immoral. Although your walking away during the course of my speech would interfere with my presentation to you, you would not (except in bizarre circumstances) wrong me by departing. It is permissible to interfere with my reading to you because that act, unlike an act of simply reading aloud, requires your participation, and your own interests in deciding whether to participate have great moral importance. Now to be sure there are ways you could wrongfully interfere with my actions in this scenario-for instance, you could snatch the paper out of my hands. But the difference is readily explained. Actions can often be described in multiple accurate ways, and the wrongfulness of interference with the action may be evident only under certain descriptions. Here, my act of reading the paper to you is also an act of reading the paper aloud, but your departure interferes with my act only under the former description because I can continue to read my paper aloud. The same cannot be said of your taking the paper away from me, which prevents me from reading the paper out loud in addition to reading it to you. When an act of labor is described in a way that implies the participation of another party-like the acts of reading to, selling to, marrying, and so forth—interference with the act so described is permissible, for all we know, because of the other party's strong interests in deciding whether to participate. Of course, if the other party has promised to participate or wishes to participate, interference might well be impermissible. And so a third person who drowned me out as I was reading my paper to you, an eager listener, would wrong both of us, but if he only made you decide you would rather not stick around to hear what I have to say and you were under no obligation to do so, neither of you would wrong me. As a rule, then, we should reserve the concept of wrongful interference with labor for cases where the labor is described in a way that does not presuppose a second party's 
participation. ${ }^{78}$ Unless otherwise indicated, the discussion below will assume that any interferedwith labor is permissible and interfered with under a description that does not imply somebody else's participation.

The foregoing remarks help clarify what sorts of labor fit within Locke's notion of interference with labor, but the relevant type of interference still needs clearer description. There are, I believe, at least three different sorts of behavior that can be characterized as wrongful interference with labor, beginning with a sort of interference in the most straightforward sense that strikes in the middle of the laborer's activities and best captures Locke's notion of meddling. This interference, which I call disruption, occurs after a person has begun doing something that can be called labor in Locke's sense, when another person comes along and either prevents the laborer from continuing with the activity so described or reverses the consequences of what the laborer has been doing for the sake of producing those very consequences. So, for example, if I make off with your lumber supply while you are in the middle of building a fence to keep vegetable-eating beasts away from your crops, I have engaged in wrongful interference of the disruptive sort because you cannot continue with your fence-building without the wood I have taken. Likewise, I disrupt your labor if I make off with the most recently installed plank or two every time you disappear to collect more lumber even if you eventually overcome the obstacle and complete your fence; here I wrong you by undoing your accomplishments. The reasons for thinking this disruption wrong are the

\footnotetext{
${ }^{78}$ I do not mean to imply that the second party's interests always justify interfering with the laborer's actions. Rather, I only mean to claim that we need some special explanation for prohibiting interference that would admittedly serve others' interests. Here is a silly example: even if it redounds to the benefit of thirsty consumers, it is not clearly permissible for Country Time to start selling its products next to a child's lemonade stand.
} 
reasons Locke cited to justify natural property rights in the Second Treatise: meddling with what you have been doing makes your pursuits more difficult and, where there are adequate other resources for me to use in my own pursuits, the burden of not bothering you is inconsequential. ${ }^{79}$

By contrast, the burden of not interfering would be oppressively high if we were generally obligated not to interfere with activities that had not even begun but were something the agent expected, intended, or wanted to do. A whole lot more of what any particular person contemplated doing would come into conflict with others' rights if duties of noninterference encompassed not only projects already underway but also projects that had been conceived of but not yet commenced. A virtue of the disruption variety of interference is that it only encompasses those actions that interfere with labor that is already happening in the world rather than sweeping in every action that makes others' success more difficult. Consider the neighbor who puts out food to attract predatory animals onto her property so they will scare off smaller creatures that have been eating her crops. If I devise a better way to attract the same predators, I have interfered with my neighbor's plans-though not with anything she yet started to do. But since there is no reason to think either of us has a better claim the predators' protection, it seems right for the principle against disruption not to forbid either of us from carrying our plans forward.

Ripstein seems concerned that Lockean duties of noninterference would prohibit many instances of intuitively permissible competition. He imagines a situation where $A$ buys the last bottle of milk while $B$ is heading to the store with the goal of purchasing milk, and Ripstein

\footnotetext{
${ }^{79}$ The burden is not entirely nonexistent, though, because it is something of a challenge for a person to take precautions ensuring that she does not interfere with others' labors and to acquire alternative natural resources if the ones already in use are more conveniently located.
} 
concludes, plausibly, that $A$ has not wronged $B$ even though $A$ has, in some sense, interfered with $B$ s activities. ${ }^{80}$ Now in dealing with this example it is tempting to take a cue from the preceding paragraph and insist that $B$ was not yet engaged in any intentional action that $A$ could be said to have disrupted. Certainly $B$ was traveling to the store, but just as certainly $A$ did not interfere with $B$ 's movement. And it is hardly obvious that $B$ was buying milk at the time that $A$ came along and grabbed the last bottle. Whether $B$ was buying milk at that time seems to depend on contingent contextual facts—such as the fact that milk typically abounds in $A$ and $B$ 's locale. Where milk shortages are rare, it may be plausible for a person to claim to be buying milk while he is making his way toward the dairy aisle. (“'’m buying milk. What does it look like I'm doing?”) By contrast, one probably could not claim to be buying milk if going to the store with money provided at most a hope of walking away with the goods. ${ }^{81}$ If you enter your name into a lottery drawing for a concert ticket and someone else walks away the winner, you would not, before the drawing occurred, claim to be getting a concert ticket. You would instead say you were trying to get a ticket or entering a drawing in order to get a ticket. But given the typical abundance of milk in grocery stores, it is not entirely clear to me that the statement " $B$ is buying milk" was false at every relevant moment of the imagined example even though it is clear that $B$ did not buy milk. Moreover, we can fill out the example with other details that make it look even more like case of interference

${ }^{80}$ RIPSTEIN, supra note 70, at 101.

${ }^{81}$ Cf. G.E.M. Anscombe, InTEntion § 23, at 40 (Harvard Univ. Press 2d ed. 2000) (1963) (“[T] he less normal it would be to take the achievement of the objective as a matter of course, the more the objective gets expressed only by 'in order to.' E.g. 'I am going to London in order to make my uncle change his will'; not 'I am making my uncle change [his] will.”'). 
with $B$ 's actual activities under a different description. Suppose $B$ is in the process of making a béchamel sauce and suddenly realizes a need to go to the grocery store to by the necessary milk. It is hard not to say that $A$ 's purchase interfered with $B$ 's béchamel-making.

However that may be, there is a more fundamental problem with Ripstein's milk example: like many examples involving competition, it presumes some sort of scarcity. The level of scarcity is never made clear, but our inclination to describe $A$ 's action as interference and justification for labeling it wrongful seem to depend on what we assume about the remaining availability of milk. If $B$ can buy milk at the pharmacy next to the supermarket, then we might rightly find no real interference to begin with. And then even if $A$ bought the last milk in town and we are inclined to describe this as interfering with $B$ 's actions, Lockean principles simply do not tell us whether or not $A$ wronged $B$. As I explained in the previous section, Locke's argument for property rights assumes away conditions of scarcity. To the extent Ripstein's example presumes not “enough and as good" milk for both $A$ and $B$, it does not envision circumstances in which Lockean natural property rights are meant to exist. If we needed to figure out who gets the milk, we would have to have principles for dealing with limited supplies of resources given multiple evidently equally deserving claimants. Such principles are quite important, of course, but Locke does not propose any. Thus the milk example cannot be a reductio ad absurdum of the suggestion that interference with labor is wrong because it strays from the background conditions necessary for Locke to condemn such interference.

Nor does the example, combined with the uncontroversial judgment that it would be wrong for $A$ to push $B$ in order to get the milk for himself, support Ripstein's conclusion that the 
“only way" $A$ could wrong $B$ here "is by wrongfully interfering with $\left[B\right.$ 's] person." ${ }^{, 2}$ It is not clear what the grounds for this inference are supposed to be, or whether Ripstein means to claim (1) that, in any case of milk buying, the only intelligible sort of interference that might be in play is interference with another's person or rather (2) that in the particular hypotheticals he proposes, where $A$ gets to the last bottle first, $A$ cannot wrong $B$ without interfering with $B$ 's person. But it seems to me either claim would be false.

First, the Lockean arguments I have been presenting show $A$ could wrongfully interfere with $B$ s actions without engaging in any sort of unwanted touching in possible scenarios near to the one Ripstein describes. Suppose $B$ has taken a bottle of milk from its shelf in the dairy section, wheeled his cart to the checkout line, and momentarily disappeared to pick up one last item. Suppose as well that $A$ watches $B$ do this. Proceeding to take the milk from out of $B$ s cart during $B$ s absence would (at a minimum) be prima facie wrongful interference with $B$ 's milk purchasing even if $A$ never makes physical contact with $B$ 's person in the process.

Second, I believe we can and should extend Locke's basic line of argument beyond cases of disruptive interference and establish that in a narrow range of cases, non-disruptive interference with another's use of resources is impermissible, even when the resources are in short supply. The milk example could be developed into such a case. Suppose that $A$ never drinks milk because of lactose intolerance, but wants to keep $B$ from having it because he is tired of hearing others sing the praises of $B$ and his wonderful sauces. Even if $A$ gets to the milk before $B$, Lockean principles allow us to say that $A$ acts impermissibly in interfering with $B$ 's efforts. For Locke, resources ought

${ }^{82}$ RIPSTEIN, supra note 70, at 101. 
to be used, and in this scenario, $B$ is the only person prepared to make use of the milk; $A$, who cannot drink milk, will only throw it out. As we know, Locke holds that waste of resources merits no protection, and $B$ would be fully justified in taking milk from $A$ given the certainty that $A$ would waste it. Similarly, it would seem to be wrong to appropriate scarce resources simply to waste them when others would put them to good use. So I believe we can identify a second type of wrongful interference, which I call spite, that occurs when one person acts in order to make another person's actual or potential labor more difficult without having any reason to do so. Unlike disruption, spite can be wrongful even when Locke's proviso is not satisfied. For what makes spiteful interference wrong is that the interferer is going out of his way to oppose the laborer's permissible attempts to create a better situation for himself without any justification for this opposition. Normally conditions of scarcity make it hard to draw definitive conclusions about who ought to be able to use the scarce resource since multiple persons have reasons for doing so. Cases of spite are different because the spiteful party is preventing others from using the scarce resource for no reason when the others do have reason to use it.

Spite also differs from disruption by applying to labor that is not yet taking place. Recall the protective predator example, which I argued did not involve wrongful disruptive interference. If I put out food to lure predators to my property to protect my own crops, I have a good reason for doing so, and even my neighbor can see that since he is acting on the same sort of reason. But if I put out food without any crops to protect, only to ensure that the rabbits on my (unjustly hated) neighbor's property continue to destroy his vegetation, I have no such reason. I seem, rather, to be competing with my neighbor only for the sake of doing him unjustified harm, and so my 
interference with his plan to benefit from the area's predatory wildlife is impermissible ${ }^{83}$ — even though he is not yet doing anything that I am disrupting. For purposes of determining whether spiteful interference has occurred, then, nothing seems to turn on whether the wrongdoer interfered with any action that his victim was already engaged in.

There is perhaps one final version of wrongful interference with labor, which I call presumption. It arises in cases where the interference is with what the laborer is doing unintentionally yet might have decided to do intentionally if she had possessed the information the interferer had. Suppose another person in Locke's state of nature finds a handsome tree that is not yet anyone's private property, and decides to transplant it to an unclaimed field nearer to where he lives simply because he likes its appearance and thinks it will provide nice shade for him to sit in on hot sunny days. At that time of planting, he does not know that it is a lemon tree but he will likely learn this information as he continues to care for it. So although he is acting intentionally under some description such as <tending to the tree $>$ and although he truly is growing lemons, he is not acting intentionally under the description <growing lemons>. Hence if I pick all the lemons off his tree without him ever realizing they were there, I have not interfered with the labor that he was intentionally performing. I have therefore not interfered with his labor according to my sense of disruptive interference. Neither have I necessarily acted with spite, for my aim may have been to have healthful fruit on hand for my own consumption. So this example does not seem to be an instance of either of the previously identified varieties of wrongful interference with labor.

\footnotetext{
${ }^{83}$ Tort law reflects this judgment as well. See Tuttle v. Buck, 119 N.W. 946, 948 (Minn. 1909) (recognizing a cause of action where defendant allegedly opened barbershop solely to drive established barber out of business).
} 
Nonetheless, Lockean principles offer some support for the conclusion that something about my lemon-picking was wrongful. This claim is perhaps counterintuitive, because the planter did not lose anything that was of value to him while I gained something that was of value to me. There seems to be no harm in what I have done. But we have to examine this aspect of the example alongside my reasons for desiring these lemons in a world of "enough and as good" where I could grow my own lemon tree or possibly pick some naturally growing lemons. The reason why I would not want to do this is presumably that it would be something of a bother to do so and much easier to take lemons that already exist. Locke, however, is insensitive to the trouble that growing my own lemon tree would put me to. At least that is how I interpret his remark that we do not generally have a right to the benefit of others' pains. And it also seems like a necessary implication of the "enough and as good" proviso. After all, if I were allowed to treat resources that another had made better through his labor as better for purposes of the proviso, it would be impossible to have property rights in many of Locke's examples. Uncultivated land is not "as good" as the land someone else has improved. So if we follow Locke on this point, the situation seems to be that it costs the planter nothing if I take the lemons and costs me nothing (that counts) if I do not. And so we might judge that it is permissible for either of us to take the lemons, with impermissibility not entering the picture. But I am reluctant to go this route. One thing the planter loses out on if I proceed to take the lemons is highly useful knowledge that he otherwise would have gained, and laborers have a strong interest in learning the natural course of events that ensues when they embark on a new project. ${ }^{84}$ If I presume to take all the lemons without notifying

\footnotetext{
${ }^{84}$ I only mean to include here the laborer's interest in learning about naturally occurring processes that do not involve other human beings. It seems to me that when labor affects other persons, they also have important privacy
} 
him or asking permission, he does not learn that he has been growing a useful and tradable resource. Even if I only take some of the lemons, and he eventually sees that the tree yields fruit, he may never become aware of the extent to which his lemon tree is valuable if he forms an inaccurate belief about its production. This loss of information seems unjustified if I can obtain substitute resources through my own labor and can inform the inadvertent lemon grower easily enough. So although this case goes well beyond Locke's explicit discussion, I am inclined to think that the planter has some sort of claim against me. This claim need not, however, correlate to a duty that I have not to take the lemons without giving their grower fair warning and the opportunity to claim the lemons for his own consumption or for trade with me. ${ }^{85}$ Perhaps it is enough that I give him an accurate description of the natural occurrence that his labor caused and my interference obscured from view. But it would be prima facie wrong, I suggest, for me to take the lemons without giving him the information he lost.

In this section, I have argued that Lockean considerations allow us to identify three distinct types of wrongful interference with labor. These can be summarized as follows:

Disruption: $A$ wrongfully interferes with $B$ s labor if (1) $B$ is acting permissibly in laboring, (2) there exists a true description $X$ of $B$ 's actions such that (a) $B$ is acting intentionally under the description $X$ in order to obtain the necessities or conveniences of life and (b) $B$ 's $X$-ing does not require another person's participation, (3) $A$ either prevents $B$ from continuing to $X$ or eliminates the intended consequences of acts that constitute $B$ 's $X$-ing, and (4) $A$ has access to

interests in not divulging all the labor's effects on them. But I do not know exactly where to draw the line when such interests conflict with the laborer's.

${ }^{85}$ Of course, if I did give the planter that opportunity and he decided not to use the lemons in either of these ways, that would be waste in Locke's sense and I would be permitted to take the lemons. 
resources of roughly the same quality as those used in $B$ 's $X$-ing that are sufficient for any labor that $A$ might wish to do.

Spite: $A$ wrongfully interferes with $B$ s labor if (1) $B$ is acting permissibly in laboring, (2) $A$ is acting in order to make it harder for $B$ to labor, and (3) $A$ has no reason to act in this way.

Presumption: $A$ wrongfully interferes with $B$ 's labor if (1) $B$ is acting permissibly in laboring, (2) there exists a true description $X$ of $B$ 's actions such that (a) $B$ is acting intentionally under the description $X$ in order to obtain the necessities or conveniences of life and (b) $B$ s $X$-ing does not require another person's participation, (3) there also exists a true description $Y$ of $B$ s $X$-ing, although $B$ does not knowingly act under the description $Y$, (4) $A$ acts in a way that would be disruption if $B$ were acting intentionally under the description $Y$ and thereby prevents $B$ from discovering that $B$ was $Y$-ing, (5) $A$ has access to resources of roughly the same quality as those $B$ was using that are sufficient for any labor that $A$ might wish to do, and (6) $A$ can easily enough inform $B$ that he had been $Y$-ing but does not do so.

Together, these definitions of disruptive, spiteful, and presumptuous interference capture the main themes of Locke's discussion of natural property wrongs and present a sharper picture of the discussion's implications. Thanks to these definitions, the concept of interfering with another's labor is clear enough to be of use in evaluating specific cases.

\subsection{LOCKEAN INTELLECTUAL PROPERTY}

One who believes property ownership is a natural right earned through effort might well suspect there are natural rights of intellectual property ownership with the same origin. ${ }^{86}$ The toils

\footnotetext{
${ }^{86}$ In the eighteenth-century words of the Massachusetts State Legislature, "the legal security of the fruits of their study and industry ... is one of the natural rights of all men, there being no property more peculiarly man's own than that which is produced by the labour of his mind." An Act for the Purpose of Securing to Authors the Exclusive Right and Benefit of Publishing their Literary Productions, for Twenty-One Years (1783), reprinted in THE PERPETUAL LAWS OF THE COMMONWEALTH OF MASSACHUSETTS 369, 369 (1789).
} 
of a musician who composes and rehearses a new work seem no less meritorious than those of an apple tree planter - at least not because the fruits of the musician's labor are incorporeal. Some such thought lies behind many attempts to model rights over intangibles after rights over tangibles, and because labor grounds Locke's justification for the latter, many have thought that his arguments furnish a natural rights-type justification for intellectual property ownership, too. Locke, however, never attempted to apply his theory to justify private ownership of information, particular ways of expressing ideas or feelings, or any other kind of intellectual things. He says nothing about intellectual property ownership in the Two Treatises. ${ }^{87}$ In later writing, he does touch upon the subject of intellectual property while arguing that Parliament should not renew the Licensing Act of 1662. That statute was one of a series of laws that gave the Stationers' Company (essentially a publishing guild) control over the whole of England's book trade. Locke's writings on this matter are informal, and consist of criticisms of the 1662 statute as well as comments on a proposed replacement statute drafted by his friend Edward Clarke of the House of

\footnotetext{
${ }^{87}$ Adam Mossoff, however, cites a passage in the Second Treatise as part of the evidence behind his assertion that "Locke explicitly recognized that his property theory justified intellectual property." Adam Mossoff, The Use and Abuse of IP at the Birth of the Administrative State, 157 U. PA. L. REV. 2001, 2048 (2009). Here is the section he cites, in its entirety:
}

From all which it is evident, that though the things of Nature are given in common, yet Man (by being Master of himself, and Proprietor of his own Person, and the Actions or Labour of it) had still in himself the great Foundation of Property; and that which made up the great part of what he applyed to the Support or Comfort of his being, when Invention and Arts had improved the conveniences of Life, was perfectly his own, and did not belong in common to others.

LOCKE, supra note 1, bk. 2, § 44, at 298-99. Although this passage does include the words "Invention and Arts," it does not hint that anyone should have exclusive rights in the intellectual goods that allow human beings to extract greater value from natural resources. It does not even say that inventing is a form of labor, as Mossoff claims. See Mossoff, supra. Inventing should qualify as Lockean labor, in my view, but this passage does not say so. I cannot see how it is even slightly relevant to the topic of natural intellectual property rights. 
Commons. ${ }^{88}$ Locke's criticisms are not shocking: he bristles at the extreme political and religious censorship agenda that lay behind the Crown's support for the Stationers' monopoly, ${ }^{89}$ and finds it "absurd" that anyone should have the sole right to print monumental works by long dead authors, least of all publishers who cannot be bothered to put together decent editions. ${ }^{90}$ In his suggestions for the draft replacement statute, Locke proposes an addition that seems at first glance to countenance some form of copyright:

To secure the author's property in his copy, or his to whom he has transferred it, I suppose such a clause as this will do ... :

And be it further enacted that no book, pamphlet, portraiture or paper printed with the name of the author or publisher upon it shall within __ years after its first edition be reprinted with or without the name of the author to it without authority given in writing by the author or somebody entitled by him, for so doing under the penalty of the forfeiture of all that shall be so reprinted to the author [or] his executors, administrators or assigns. ${ }^{91}$

Without more, though, we should not conclude that the language Locke suggests adding bespeaks his personal endorsement of intellectual property ownership. The passage does not disclose Locke's motivation for trying "[ $\mathrm{t}] \mathrm{o}$ secure the author's property." It might have been that he felt strongly about this issue as an author and natural rights theorist, ${ }^{92}$ but that is just speculation. In fact,

${ }^{88}$ See John Locke, Liberty of the Press, in PolitiCAL EsSAYs 329, 329 (Mark Goldie ed., 1997) (1694-1695).

${ }^{89}$ Id. at $330-31$.

${ }^{90}$ Id. at 333; see also id. at 337 ("That any person or company should have patents for the sole printing of ancient authors is very unreasonable and injurious to learning.").

${ }^{91} I d$. at 338. Locke offers an alternative as well. See id. at 338-39.

92 See Lior Zemer, The Making of a New Copyright Lockean, 29 HARV. J.L. \& PUB. POL'Y 891, 902 (2006); cf. Justin Hughes, Locke's 1694 Memorandum (and More Incomplete Copyright Historiograpbies), 27 CARDOZO ARTS \& ENT. L.J. 555, 560 (2010) ('Locke's choice of 'secure[ing]' the 'author's property' may intimate a preexisting right and 
Locke was clearly responding to a concern explicitly raised in the letter to which he was replyingto wit, the Stationers' Company (among others) opposed Locke's friend's proposed legislation because, in the words of Locke's correspondents, they found it "wanting as to the Securing of Property." ${ }^{\prime 93}$ Those who wish to see Locke as personally committed to intellectual property rights overlook the fact that this securing property language was not Locke's own. ${ }^{94}$ Within its context, then, Locke's suggestion seems to reflect political strategy more than philosophical conviction. The only certainty in any of this, though, is that Locke nowhere developed an argument for intellectual property rights.

From a philosophical perspective, of course, it is more important to figure out whether Locke's arguments support natural rights of intellectual property ownership than whether he himself did. Surely the concept of labor includes making and improving the sorts of things that intellectual property law protects, whatever Locke's own thoughts on the matter. ${ }^{95}$ One suspects that those who invest time and energy developing copyrightable works, discovering useful new information, or marketing their goods using distinctive symbols are ordinarily doing so for the purpose of obtaining the necessities and conveniences of life. Beyond this threshold determination

Locke also makes a comment in the memorandum that may hint at some natural rights-based property interest being trampled by the then Licensing Act.").

${ }^{93}$ Letter from John Freke \& Edward Clarke to John Locke (Mar. 14, 1695), in 5 THE CORRESPONDENCE OF JoHn LOCKE 291, 291 (E.S. De Beer ed., 1979).

${ }^{94}$ The Freke/Clarke phrasing receives no mention, for instance, in Hughes, supra note 92; Mossoff, supra note 87; or Zemer, supra note 92, all of which take for granted that the phrasing is Locke's own.

${ }^{95}$ Compare LOCKE, supra note 27, at 10 (describing himself as "an Under-labourer in clearing Ground a little, and removing some of the Rubbish, that lies in the way to Knowledge"), with John Locke, Labour, in PoLiTICAL EssaYs, supra note 88, at 326, 328 (1693) (distinguishing between the "thought and reading" of the "gentleman and scholar" and "honest labour"). 
that intellectual labor qualifies as true labor, many commentators have gone on to conclude that Locke's labor theory of property does indeed support exclusive rights over intellectual objects as much as or more than it supports exclusive rights over tangible ones. Given the interpretation of Locke's theory I developed above, that conclusion would seem to depend on the extent to which intellectual property ownership prevents interference with intellectual labor.

In my view, the standard incidents of intellectual property ownership go far beyond protecting intellectual labor from interference-especially within the areas of copyright and patent law. To see this, let us think through a few examples, supposing that I am in some Lockean state of nature going about my business. If I come upon a person singing a song of her own creation and take out my tablet and stylus to jot down the lyrics and chord progression because I like the song and want to remember how it goes, I am not disrupting anything that this person is doing. For this way of giving physical embodiment to her song does nothing to restrict her ability to continue singing or developing the song as she pleases, nor have I undone any of her accomplishments. I have not, therefore, engaged in any disruptive interference nor, it would appear, in any spiteful or presumptuous interference, even though I have acted in a way that would constitute a violation of an intellectual property owner's excluding privilege to embody her work. Likewise, I do not interfere with her labor if I deny her the standard incidents of development and distribution by arranging the song in an alternative way or publicly performing it within the community.

Now imagine that I have found not a singer but a wheeled handcart, which some clever person has invented to transport heavy objects long distances. Although making off with the prototype for my own use would be a clear case of wrongful interference (assuming that the 
inventor is still making use of it), I would not be interfering with the inventor's labors if I go home to replicate the cart for my use, or if I alter its design so that it may be pulled by beasts of burden, or if I trade the carts I have made to our co-citizens in the state of nature. She would remain as capable of using her cart and her design after my actions as before.

One might dispute this claim, however, by pointing out that she can no longer continue to use the cart in one particular way. Specifically, once she begins selling carts or the information needed to make them to buyers, their subsequent unauthorized use of her design may interfere with her ability to continue profiting from it financially. This observation is correct, but not indicative of Lockean natural property rights. ${ }^{96}$ Recall that interference with labor is not wrongful when the labor depends on the participation of another person and that person is neither obligated nor eager to participate. The reason is that that other person has her own interests, and to determine what treatment the laborer is owed we must account for those interests alongside the laborer's interests. Thus while it is true that infringers can limit intellectual property creators' ability to sell or license their creations for commercial gain, such actions are impermissible interference only if the would-be buyers or licensees themselves wish or have a duty to buy a product or license from the intellectual property owner. In the crucial sort of case, infringers are not interfering with any sales to those preferring to buy from the intellectual property creator; rather, they are luring willing buyers away from the owner by charging a lower price. And without some independent reason to think that the buyer is obligated to buy from the creator herself, this objection simply begs the question. As I understand Locke's labor theory, then, it does not offer a

\footnotetext{
${ }^{96}$ In Chapter 4, however, I will argue that this sort of point is quite important to our moral duties after intellectual property law has been instituted for the purpose of advancing the common good.
} 
natural rights-type justification for the standard incidents of embodiment, development, or distribution in paradigmatic cases of copyright and patent infringement.

The situation is quite different, though, within the domain of trademark law. Imagine that the cart-inventor also produces and sells her carts, marking them all with a distinctive symbol to indicate that she was the person who produced them. Perhaps she does so because everyone knows that her products are extremely well made and willingly pays more for them than for alternatives. If I put that symbol on the carts I make and thereby lead cart-buyers to believe that the carts I am selling were actually made by inventor/producer herself, I quite likely interfere with her ability to communicate to the buying public. If my carts are not as well made as hers, I disrupt her labor by undoing the intended results of her efforts to establish a good reputation for her products.

Additionally, if word gets out that I am using her symbol too, she can no longer continue using it to inform buyers that she is the one who made the carts bearing the symbol. This interference harms her, and often harms consumers as well, who presumably prefer to have accurate information about the things they buy. ${ }^{97}$ Furthermore, since plenty of other symbols remain for my legitimate purposes, Locke's proviso is generally satisfied in a case like this one. ${ }^{98}$ And so when

\footnotetext{
${ }^{97}$ That consumers have such a preference may well be doubted, especially to the extent that a trademark infringer sells comparable goods at a significantly lower price. In the next chapter, I advance an argument for trademark rights that does not depend on consumers' preferring not to be deceived about the source of the goods they are buying.

${ }^{98}$ As others have noted, however, the proviso is not invariably satisfied in trademark disputes. See, e.g., Wendy J. Gordon, A Property Right in Self-Expression: Equality and Individualism in the Natural Law of Intellectual Property, 102 YALE L.J. 1533, 1590 (1993) (explaining how poorly designed trademark laws could fail to leave individuals with enough and as good ways of expressing their views). For instance, someone who is blocked by trademark from using his own name to describe his goods has arguably not been left with enough and as good symbols for his own legitimate use. Cf. Hyatt Corp. v. Hyatt Legal Servs., 736 F.2d 1153 (7th Cir. 1984) (ruling against trademark defendant for using his own last name in naming his business).
} 
I pass off my goods as my rival's without sufficient reason-and I take it for granted that misleading potential customers for my personal gain does not suffice-the harm to her and to consumers is unjustified. To be sure, modern trademark doctrine covers much more than this simple example. But at least this core case of trademark infringement can be seen as morally wrongful using the Lockean model I am defending. ${ }^{99}$

\subsection{ALTERNATIVE UNDERSTANDINGS OF LOCKEAN INTELLECTUAL PROPERTY}

Of course those who believe Locke's labor theory goes further in justifying intellectual property ownership interpret it rather differently than I do, and so we must examine the differences and the reasons behind them. These scholars tend to line up behind one or more of three positions, each of which is, I argue, mistaken on the merits and as an interpretation of Locke.

Alternative \#1: Treating the Lockean Proviso as a Sufficient Condition for Exclusive Property Rights

The first alternative line of argument on behalf of Lockean intellectual property argues (1) that claiming ownership of presently unowned things through labor is justified whenever it leaves nobody else worse off than they otherwise would have been, (2) that, in the relevant sense of "worse off," intellectual property ownership makes no one worse off than they otherwise would

\footnotetext{
${ }^{99}$ This conclusion is consistent with Mark McKenna's historical account of trademark's justifications. He argues that trademark originally prohibited passing off in order to protect producers from unfair competition, but has since been expanded in ways that go beyond this grounds of justification. See Mark P. McKenna, The Normative Foundations of Trademark Law, 82 NotRE DAME L. REV. 1839, 1843-44 (2007).
} 
have been, and then concludes (3) that intellectual property ownership is justified. It is true that intellectual property rights do not typically worsen the position of non-owners: if they remain free to engage in their own intellectual labor irrespective of the innovation that preceded them, intellectual property does not necessarily limit their opportunities to interact with ideas and creative expression. ${ }^{100}$ Let us assume, then, that intellectual property rights will generally comply with Locke's proviso. ${ }^{101}$ The more severe problem with this argument is in proposition (1), which treats satisfaction of Locke's proviso as a sufficient condition for property rights. Some defenders of natural intellectual property rights frankly acknowledge that they are construing Locke's enoughand-as-good proviso as a sufficient condition. ${ }^{102}$ The problem with the construction is that it is hard to defend as a substantive matter and clearly inconsistent with Locke's text.

\footnotetext{
${ }^{100}$ Current intellectual property law, however, does not conform to this generalization. Whereas copyright law recognizes independent creation as a defense against infringement allegations, patent and trademark law do not. Compare Selle v. Gibb, 741 F.2d 896, 901 (2d Cir. 1984) ("Proof of copying is crucial to any claim of copyright infringement ...."), with Kewanee Oil Co. v. Bicron Corp., 416 U.S. 470, 478 (1974) (noting that patent protection prohibits not only actual copying of the patented invention but also "independent creation" of it), and Rebel Debutante LLC v. Forsythe Cosmetic Grp., 799 F. Supp. 2d 558, 575 (M.D.N.C. 2011) (examining whether the defendant's use of a trademark "originated independently" from the plaintiffs as one non-dispositive factor in determining whether it was likely to confuse consumers).

${ }^{101}$ Wendy Gordon, however, has argued that an intellectual property can in some hypothetical circumstances worsen non-owners' overall position by exposing them to an idea or form of creative expression and then invoking intellectual property rights to restrict their use of it severely. Gordon, supra note 98, at 1567-70. I am not so sure about the force of her examples, but since my aim is to make an independent argument against the idea that Locke's theory supports strong intellectual property rights, this is no place to explore doubts about Gordon's very interesting argument.

102 Adam Moore does this most clearly. See ADAM D. MOORE, InTELLECTUAL Property AND INFORMATION CONTROL 106-07, 108 (2d prtg. 2004). Wendy Gordon's analysis of Locke is more difficult to interpret, because she asks rhetorically how the proviso could be anything other than a sufficient condition even while acknowledging Locke's prohibition against waste and duty of charity. See Gordon, supra note 101, at 1565 \& n.179.
} 
The general thought behind treating the proviso as a sufficient condition for property seems to be that doing so is unobjectionable because it only justifies ownership that leaves no one harmed: "no harm, no foul." ${ }^{103}$ But this thought can do little philosophical work in the intellectual property setting. As I argued in the Chapter 1, ambiguous terms like "property" and "ownership" obscure highly relevant details—specifically, which entitlements the "no harm, no foul" principle must justify. Now, if no one is harmed, an intellectual property creator is almost certainly entitled to use her creation. Intellectual property ownership, however, is controversial only because it includes, besides the owner's right to use, various rights against others that they not use the new creation in certain ways even though they would benefit from so doing and their use and enjoyment would not jeopardize the owner's. If we endorse the "no harm, no foul" principle, we are committed to accepting others' use of the creation if it does not harm the owner. As with any harm-based principle, we must determine a baseline from which to measure the relevant sorts of harm. Obviously it will not do simply to respond that non-owner use harms (or otherwise wrongs) the intellectual property creator by violating her rights to exploit her innovation commercially, because that is the very question at issue. ${ }^{104}$ To justify the standard incidents of intellectual property ownership using this argument, then, we need some independent grounds for concluding that unauthorized embodiment of intellectual property, for example, harms or wrongs its creator. And no such grounds have yet been proposed.

\footnotetext{
${ }^{103}$ MOORE, supra note 102, at 109, 114.

${ }^{104}$ It would be just as circular, from the opposite perspective, to resist the "no harm, no foul" argument in support of intellectual property by insisting that not having access to intellectual property harms non-owners.
} 
In any case, Locke himself seems to reject the "no harm, no foul" principle. Although it is possible to take apples from common trees without violating the enough-and-as-good proviso, ${ }^{105}$ Locke claims that taking those apples and failing to use them before they spoil wrongs others. ${ }^{106}$ But the apple-taker's waste of the apples on a single occasion does not make others any worse off than they would have been had he eaten them instead. If the appropriation of those apples is no proviso-violating harm in the first case, neither is it in the second case. Committing harm, in the sense of making others worse off, is therefore not strictly necessary in Locke's view to commit a foul. ${ }^{107}$ Locke repeatedly insists that wasteful appropriation is impermissible whether or not the proviso is violated. ${ }^{108}$ Given Locke's conviction that waste is impermissible, it is hard to maintain that he accepts the proviso as a sufficient condition for justified appropriation.

\section{Alternative \#2: Interpreting Locke's Opposition to Waste Quite Narrowly}

Many who believe that Locke's theory justifies intellectual property also acknowledge that his views about waste place a further constraint on appropriation beyond the enough-and-as-good proviso. They think, though, that the waste prohibition simply does not pose a serious barrier to

${ }^{105}$ See LOCKE, supra note 1, bk. 2, § 28, at 288.

${ }^{106} I d$. bk. $2, \S 46$, at 300 .

${ }^{107}$ The view that a person may be wronged without a reduction in his overall level of well-being remains a live one today. See, e.g., James Woodward, The Non-Identity Problem, 96 ETHICs 804, 808-11 (1986).

${ }^{108}$ See id. bk. 2, §§ 31, 37 38, 46, at 290, 295, 300. 
justifying intellectual property's standard incidents. ${ }^{109}$ Some of these writers reach this conclusion simply by observing that intellectual property does not perish in the same way as the examples Locke produces to illustrate his waste prohibition. ${ }^{110}$ Locke singles out hunters and gatherers who let their venison putrefy and their fruit rot. ${ }^{11}$ Ideas and creative expression are not victims of this sort of decay, and their imperishability can make the waste prohibition seem out of place. ${ }^{112}$ Other commentators have thought through the possibility of intellectual property waste more carefully but still concluded that it does not significantly constrain intellectual property ownership. For instance, Robert Merges insists Locke's interpreters need a deeper understanding of waste than a quick mention of superficial features of the Second Treatise examples, and ultimately he advances an interpretation of Locke's opposition to waste that does rather little to constrain on intellectual property ownership. To waste what one owns, Merges claims, the owner "must truly not use it at all, must let it go completely to waste."113

Now, it is true that if we care only about "abject waste," ${ }^{114}$ to use Merges's label, we will not find ourselves tempted to think waste undermines the standard incidents of intellectual

${ }^{109}$ See, e.g., Robert P. Merges, Justifying Intellectual Property 66 (2011); Justin Hughes, The Philosophy of Intellectual Property, 77 GEO L.J. 287, 300 (1988) ("We can justify propertizing ideas under Locke's approach with three propositions: first, that the production of ideas requires a person's labor; second, that these ideas are appropriated from a 'common' which is not significantly devalued by the idea's removal; and third, that ideas can be made property without breaching the non-waste condition.”).

${ }^{110}$ See, e.g., Hughes, supra note 109, at 328.

${ }^{111}$ LOCKE, supra note 1, bk. 2, §37, at 295.

$112 C f$. id. bk. 2, § 46, at 300 (claiming that hoarding "durable" items like shells, pebbles, diamonds would not necessarily violate the waste prohibition).

${ }^{113}$ MERgES, supra note 109, at 57.

${ }^{114} I d$. at 61 . 
property. Abject waste of expression or information seems relatively rare. Sure, a creator might decline to do anything useful with some very important thoughts, or even go so far as to create an embodiment of her thoughts but then leave the thing embodying them in utter disuse. ${ }^{115}$ One can also imagine abject waste by a creator's choice to destroy all embodiments of her creation (such as all copies of her artwork) or some physical materials necessary to benefit from her creation, such as research notes. ${ }^{116}$ Situations like these, however, arise infrequently and constitute only a minimal limitation on the justifiability of intellectual property rights. One could see, then, the appeal of the suggestion that natural intellectual property rights exist because they ordinarily result neither in waste nor in violation of the enough-and-as-good proviso.

Although Merges deserves credit for thinking about why the waste prohibition exists instead of simply relying on obvious differences between intellectual property and Locke's examples of wasted physical objects, his abject waste standard is too strict. Let us set aside intellectual property for the moment and reconsider spoilage of physical objects. Suppose an inhabitant of Locke's state of nature greatly enjoys root vegetables and successfully grows and survives on turnips, beets, carrots, and radishes, among others. Despite his fondness for healthful produce, however, this character turns out not to like leafy greens and so never makes use of these vegetables' edible tops. He simply removes and discards the turnip greens, beet greens, and so on.

${ }^{115}$ See id. at 58. Merges also thinks it is possible to commit waste by claiming ownership of variants of one's creation that the claimant never produces. Id. at 58-59. But he ultimately downplays this possibility because such aggressive claims can prove useful to the owner by preventing competition. Id. at 60 . And he also points out that it is hard to tell in advance whether the aggressive claimant will eventually decide to make use of the variations. Id. at 61. After these qualifications, it is hard to see how on Merges's understanding of it the waste prohibition meaningfully restricts intellectual property rights.

${ }^{116}$ See, e.g., Gordon, supra note 101, at 1551. 
Salad lover that I am, I approach him about the possibility of mutually beneficial exchange.

Unfortunately, he is none too impressed by my heirloom arugula or anything else I have to offer.

Self-sufficient and somewhat standoffish, he is not particularly enthusiastic about working out a deal but also does not want to give me something for nothing. So we cannot agree to terms. On my way out, I notice his cutting board and take a handful of already-removed radish greens with me, knowing with certainty that he would make no use of them. As I understand it, Merges's conception of Lockean waste forbids this—-because the radish-grower was getting some use out of what he was producing through his labor. ${ }^{117}$ At the same time, though, Merges apparently would agree that I could permissibly take this man's lettuce in similar circumstances if he had cultivated some by mistake. There would be abject waste of the lettuce he has grown, but not the radishes, because its grower has absolutely no use for any part of the former. But why treat these two takings differently? No reason leaps to mind.

Locke does not address any examples of what might be called partial waste, but what he does say seems more consistent with classifying as permissible my hypothetical taking of the radish greens. Although Merges quotes Locke's condemnation of waste, he does not cite any passage in particular to support his abject waste standard. ${ }^{118}$ Yet there is some evidence that calls that

\footnotetext{
${ }^{117}$ I interpret Merges as committed to this result because if he were instead to respond by distinguishing between use/waste of the roots and use/waste of the greens, he would be opening the door to a much broader application of the waste prohibition to intellectual property. For just as plants can be carved up according to different compatible uses, so too can creative expression (and innovative ideas), perhaps to an even greater degree. Imagine that Thomas Edison is marketing his light bulb in New Jersey but not in Delaware. And that J.K. Rowling is developing a movie for the Harry Potter franchise but not a stage show. Surely Merges would not want to say, in those circumstances, that someone else could sell Edison's inventions in the First State or bring Hogwarts to Broadway without the creators' permission. Such a concession would recognize significant limits to the standard incidents of distribution and development.

${ }^{118}$ See MERGES, supra note 109, at 49, 56-61.
} 
standard into doubt as a faithful reflection of Locke's own views. Twice, Locke states that the scope of natural property rights is bounded by the right-holder's use and enjoyment of the resource. After introducing his idea that it is permissible to use up the common stock through labor, Locke explains:

The same Law of Nature, that does by this means give us Property, does also bound that Property too. God has given us all things ricbly, 1 Tim. vi. 17. is the Voice of Reason confirmed by Inspiration. But how far has he given it to us? To enjoy. As much as any one can make use of to any advantage of life before it spoils; so much he may by his labour fix a Property in. ${ }^{119}$

By claiming that property rights are justified as "far" as they promote enjoyment, Locke indicates that enjoyment of resources constitutes not only the purpose of property rights, but also sets the limit to which they extend. Locke reiterates this position later when he explains why the person who wastes food has done wrong: "he had no Right, farther than bis Use called for any of them, and they might serve to afford him Conveniences of Life." ${ }^{120}$ These two passages suggest Locke's views about waste are ultimately grounded in the thought that property rights extend only so far as is necessary to protect the owner's use and enjoyment of what she owns. In other words, property rights simply protect against interference, and taking steps to use property that is being wasted is permissible because it does not interfere. For the most part, then, Locke's views about waste merely reinforce the central theme of his argument for property rights as I have interpreted it: unauthorized uses of property that do not impair the owner's use and enjoyment of it do not

${ }^{119}$ LOCKE, supra note 1, bk. 2, § 31, at 290.

${ }^{120}$ Id. bk. 2 , § 37, at 295. Note that Locke expressly recognizes trade or donation of a resource as the right sort of use of it. Id. bk. $2, \S 46$, at 300 . 
violate Lockean property rights. ${ }^{121}$ My unauthorized consumption of the radish greens would not conflict with any use the grower had for the produce of his labor and would not be wrongful because, as Locke might put it, the right called for by the grower's use extends only to the radishes themselves. This view about waste further suggests that (other things equal) it is permissible to use another person's intellectual property without authorization to the extent that use does not interfere with the owner's use of it. ${ }^{122}$

${ }^{121}$ Although we reach nearly the same bottom line, my argument differs at this very point from the one advanced by Seana Shiffrin in her important article on Locke and intellectual property. She argues that the best interpretation of Locke's view holds that any resource is owned in common if "fully effective use" of it does not require that only one person (or a few) have exclusive rights to it. Seana Valentine Shiffrin, Lockean Arguments for Private Intellectual Property, in New Essays in the Legal and Political Theory of Property 138, 152 (Stephen R. Munzer ed., 2001). This approach, like mine, denies that Lockean principles much support intellectual property rights by emphasizing the so-called non-rivalrousness of intellectual property. But I am not attracted to Shiffrin's idea of dividing possible objects of intellectual property into a category that requires exclusivity for fully effective use (and therefore is a proper object for private ownership) and a category that does not (and therefore is not). It is not clear that many physical objects-including resources that Locke's account certainly seems to support exclusive rights inrequire exclusivity for fully effective use, as Shiffrin herself seems to acknowledge. See id. at 163. The only obvious examples of objects that do require exclusivity for fully effective use are items that are fully consumed, like food, and highly personal items like toothbrushes, undergarments, engagement rings, and (maybe) homes. I confess, however, that I am not entirely sure what Shiffrin means by "fully effective use." Instead of focusing on whether resources fall into one or the other of Shiffrin's two categories, I prefer to view the existence of exclusive rights as turning on whether the putative duty-holder's actions would disrupt or otherwise interfere with the putative right-holder's actual use of the relevant good.

${ }^{122}$ At least three other writers have argued that Locke's conception of waste limits natural intellectual property rights, but they see it only as a second "proviso" or a moral principle standing free of the rest of Locke's argument for private property rather than as a corollary of the natural rights against interference that Locke justifies. E.g., Daniel Attas, Lockean Justifications of Intellectual Property, in INTELleCtUAL PROPERTY AND THEORIES OF JUSTICE 29, 45 (Axel Gosseries et al. eds., 2008); Gordon Hull, Clearing the Rubbisb: Locke, the Waste Proviso, and the Moral Justification of Intellectual Property, 23 PUB. AFF. Q. 67 (2009); Benjamin G. Damstedt, Note, Limiting Locke: A Natural Law Justification for the Fair Use Doctrine, 112 YALE L.J. 1179, 1193-94 (2003). Perhaps because they do not draw the connection between the scope of Lockean property rights and the waste prohibition, they propose differing formulations of the prohibition. Compare Hull, supra, at 81 ("[S]poilage occurs when (a) there is irrevocably unmet demand, (b) the goods to satisfy that demand already exist, and (c) property claims prevent satisfaction of those demands."), with Attas, supra, at 47 (describing waste as "the recklessly suboptimal use of resources"), and Damstedt, supra, at 1194 ("Waste occurs where a unit of a product of labor is not put to any use."). Although I agree with these three that the waste prohibition is important for understanding Lockean intellectual property, I do not endorse any of their formulations. 
There is, however, one potential text-based objection to my use of the waste prohibition. Every time Locke condemns waste, he does so in the context of resources that were once in the commons. Indeed, he voices his condemnation in terms of wasting "the common Stock" and destroying "part of the portion of Goods that belonged to others," 123 and insists, "Nothing was made by God for Man to spoil or destroy." ${ }^{124}$ Copyrighted works and patented inventions, it is fair to say, do not exist before some human creates them, and so it seems entirely possible that intellectual property ownership does not usually require removing anything from the commons. Intellectual property ownership differs in this respect from ownership of land or naturally growing food or the other resources that Locke identifies as things that can be wasted. To be sure, innovation relies enormously on others' previous accomplishments, but it is only what the innovator adds, not what she takes, that could possibly be described as wasted by the exclusivity that intellectual property rights guarantee. So one might argue that Lockean waste places no significant limits on intellectual property ownership because the owner "has not deprived consumers of anything in the common" whereas the person who wastes natural resources has done exactly that. ${ }^{125}$

In my view, this argument misunderstands the common ownership thesis. Recall that, for the purposes of Locke's discussion, common ownership is a problem to be overcome in any defense of property rights: How can it be permissible for somebody to remove something from the

\footnotetext{
${ }^{123}$ LOCKE, supra note 1, bk. 2 , § 46, at 300.

${ }^{124}$ Id. bk. 2, § 31, at 290 (emphasis added).

${ }^{125}$ David McGowan, Copyright Nonconsequentialism, 69 Mo. L. REv. 1, 48 (2004).
} 
commons for his own sole use, Locke asks, unless everyone else grants him permission to do so? ${ }^{126}$ Locke's own solution, as we saw above, was to take it for granted that God gave humanity everything in common so that they could enjoy it, and then to conclude that it must be permissible to make use of these common things, even to the exclusion of others if necessary. ${ }^{127}$ In non-theological terms, the common ownership thesis simply says that anyone who can use and enjoy something without giving others cause to complain should be free to do so. And Locke was hardly the first person to advance this claim. Cicero, whose ethical writings Locke knew and admired, ${ }^{128}$ held that that we ought "to bestow even upon a stranger what it costs us nothing to give." ${ }^{129}$ In support of this counsel, Cicero pointed to the Roman poet Ennius, who had noted that the person who lights his lamp by another's fire does not make that fire shine any less brightly. ${ }^{130}$ Today, this imagery is more familiar from Thomas Jefferson's oft-quoted work opposing natural rights of intellectual property and often thought of as opposing Locke's views too: "He who receives an idea from me, receives instruction himself without lessening mine; as he who lights his taper at mine, receives light without darkening me."131 But nothing in Locke's writings gives us

${ }^{126}$ See LoCKE, supra note 1 , bk. $2, \S 25$, at 286.

${ }^{127}$ Id. bk. $2, \S 26$, at 286-87.

${ }^{128}$ John Locke, Some Thoughts Concerning Reading and Study for a Gentleman, in POLITICAL EsSAYS, supra note 88, at 348, 351 (recommending Cicero's De Officiis to one wishing "to see how far the heathen world carried that science" of morality without aid from the New Testament Gospels) (1703).

${ }^{129}$ CiCERO, De OfFiciIs bk. $1, \S 16$, at 55 (Walter Miller trans., 1913) (44 B.C.).

${ }^{130} I d$. bk. $1, \S 16$, at 55 .

${ }^{131}$ Letter from Thomas Jefferson to Isaac McPherson (Aug. 13, 1813), in 13 THE Writings OF THOMAS JEFFERSON 326, 334 (Albert Ellery Bergh ed., 1907). 
reason to think he would have disagreed. It is much more likely that he would have found it permissible to avert waste of most things—even those things that never were natural resourceswhen using them did not interfere with others' labor.

As we have seen, however, there are really two distinct parts to Locke's view on waste: the permissibility (for non-owners) of averting waste through non-interfering use, ${ }^{132}$ and also the impermissibility (for owners) of causing waste. ${ }^{133}$ To my mind, the second part of this view often would be implausible if extended to non-naturally occurring ideas and creative expression. Those who create an expressive work, for instance, may be entirely justified in not sharing it for a variety of reasons. By way of example, just think of someone's privacy interests in the contents of a personal journal. Or of artists' interests in only releasing work once they are happy with it. True, some artists have been known for holding themselves to unreasonably high standards, but at least as a general matter it seems those who create intellectual property bear no obligation to share iteven though that might be counted as waste- beyond what duties of beneficence require in other areas of morality. To some extent, the two parts of Locke's view on waste are independent. And regardless of the impermissibility (or not) of intellectual property owners' decisions to cause waste, it seems to me entirely justified to count non-owners' non-interfering use of others' intellectual creations as permissible. But I will now turn to another argument to the contrary.

\footnotetext{
132 See LOCKE, supra note 1, bk. 2, § 38, at 295 (claiming that land wasted by one person "might be the Possession of any other").

${ }^{133}$ See, e.g., id. bk. 2, § 37, at 295 (describing waste as an "offen[se] against the common Law of Nature”).
} 


\section{Alternative \#3: Arguing That It Is Typically Wrong to Benefit from Others' Efforts for Free}

Finally, Locke's arguments can seem to support intellectual property rights on the theory that the person who has worked to create a valuable resource more deserves to benefit from it than the person who has not put in that work. The person who benefits from another's work without contributing anything is frequently denounced for free-riding ${ }^{134}$ or for reaping where he has not sown. ${ }^{135}$ Both formulations find something unfair and impermissible in freely benefiting from another person's efforts without getting prior permission or giving adequate compensation.

Varieties of this argument do not try to establish that the standard incidents of intellectual property ownership are exactly what the laborer is owed for his efforts. The laborer may have a claim to some reward for adding value to others' lives, but not necessarily an excluding privilege to embody, develop, or distribute. ${ }^{136}$ Monetary compensation might be adequate, although it is unclear how we would calculate the proper amount of compensation because intellectual property creators are never solely responsible for every last bit of their creation's value. ${ }^{137}$ The principal claim

${ }^{134}$ E.g., David J. Franklyn, Debunking Dilution Doctrine: Toward a Coberent Theory of the Anti-Free-Rider Principle in American Trademark Law, 56 HASTINGS L.J. 117, 139-40 (2004).

${ }^{135}$ E.g., Int'l News Serv. v. Associated Press, 248 U.S. 215, 239 (1918); Jonathan Peterson, Lockean Property and Literary Works, 14 LEGAL THEORY 257, 276 (2008).

${ }^{136}$ See, e.g., Wendy J. Gordon, On Owning Information: Intellectual Property and the Restitutionary Impulse, 78 VA. L. REv. 149, 192 (1992); Edwin C. Hettinger, Justifying Intellectual Property, 18 PHIL. \& PUB. AFF. 31, 41 (1989). Jonathan Peterson, however, argues that a "maker's right" interpretation of Locke-according to which a thing's maker has a right to what he has made (rather like the way God, on Locke's view, has rights to the human beings He creates) - explains why intellectual resource creators are owed some sort of what I call excluding privileges. See Peterson, supra note 135, at 277; see also GOPAL SREENIVASAN, THE LIMITS OF LOCKEAN RIGHTS IN PROPERTY 62 (1995) (advocating the maker's right interpretation of Locke). For reasons that John Simmons has laid out, I do not believe the maker's right argument is plausible either as an interpretation of Locke or as a general theory of property rights. See Simmons, supra note 35, at 197.

137 See, e.g., Gordon, supra note 136, at 190-91; Hettinger, supra note 136, at 37-38. 
here is that it is wrong for someone to benefit from another's work for free, at least if the laborer intends to be compensated for the benefits her work produces. Yet I think this intuition, though common enough in intellectual property discussions, ${ }^{138}$ is rarely correct and in some tension with Locke's arguments.

Before testing the intuition, let us set aside a couple of possible distractions. First, no one denies that compensation is normally required of the person who solicits the work of another while encouraging the laborer to expect compensation. And of course there will be hard cases for determining whether a beneficiary encouraged the laborer's expectation of compensation. So in a case testing the intuition, the decision to undertake the labor should be made without the beneficiary's active influence. Second, since the case for required compensation is weakest when the benefit conferred and effort expended are both negligible, we should assume that the laborer exerts himself considerably and the beneficiary receives a substantial benefit.

With those points out of the way, consider the following case:

Stage of Nature. While walking through the unclaimed wilderness, Anthony hears distant music, which, upon closer investigation, proves to be famed tenor Juan Diego performing a notoriously difficult aria. Not only are the ringing high notes and bel canto passage-work physically demanding, but Juan Diego has also spent much effort over the years training his voice and even paid an orchestra on this occasion to make recordings for sale. Anthony, a life-long opera lover, moves closer to get a good listen and then enjoys a first-rate performance.

${ }^{138}$ See, e.g., Lawrence C. Becker, Deserving to Own Intellectual Property, 68 CHI.-KENT L. REv. 609, 624 (1993) ("A person who produces a public benefit, by way of morally permissible (but not required) actions, deserves to receive a fitting and proportional benefit from the public for doing so.”). 
Does Anthony owe Juan Diego compensation for the former's entertainment and the latter's troubles? In my view, the answer is no. Perhaps Anthony should reciprocate if he finds himself in a position to provide a benefit to Juan Diego later on at no significant cost to himself-for example, by sharing his (not-secret) family recipe for sautéed radish greens. And perhaps Juan Diego deserves Anthony's praise, admiration, or gratitude. But what seems implausible is that Anthony needs to suffer some detriment or identify some benefit to give Juan Diego on pain of having acted wrongly—as though the benefit he received from witnessing the performance needed to be evened out somehow. My claim is that Juan Diego does not have a right any such behavior from Anthony. Those who have an intuition that at least some uncompensated, unauthorized benefiting from another's labor is wrongful stress that lack of compensation can threaten the laborer's ability to earn a living through her labor. ${ }^{139}$ But this threat constitutes grounds for complaint only if she can justifiably expect to be able to earn a living through the particular sort of labor she has engaged in. And it is hard to see what would justify such an expectation once we set aside the possibility that the beneficiary has encouraged it. There does not seem to be any general principle justifying an expectation of financial support from others when one does things that benefit them, whether this benefit is judged objectively or from the supposed beneficiaries' own perspectives. Perhaps it would benefit me if some person truthfully (let us suppose) and convincingly spoke well of me in front of lots of people. Still, no one has a right to employment as my publicist.

139 See, e.g., MERGES, supra note 109, at 41 (rooting an intellectual property-related right "to earn something" for one's labor in one's interest in flourishing); Gordon, supra note 101, at 1548. 
In a relatively small subset of free-riding cases, however, an expectation to be compensated might be justified for other reasons. Consider, for example, this scenario:

Pain in the Neck. The entire local population has recently begun to experience moderate chronic pain, the cause of which remains unknown. Everyone has agreed to pool resources to find a cure, except for one person who consistently refuses to contribute. When others discover through great effort that a local herb relieves the pain, the non-contributor makes use of this knowledge to relieve his own pain but declines to compensate those whose work uncovered the cure. ${ }^{140}$

If what the non-contributor does here is open to criticism, the explanation, I suggest, is not merely that he is free-riding on others' substantial efforts and deriving a substantial benefit for himself. Rather, the operative fact is that he did so when he had decisive reason to direct some of his own effort to pursuing the particular benefit before the possibility of obtaining it through free-riding arose. Had they never approached him, his suffering would still have given him strong reasons to try to accomplish their goal, perhaps in cooperation with others. Others' expectation that he would sign onto their project seems entirely justified — at least on the assumption that the odds of finding a cure never seemed hopeless. So the wrongfulness of failing to compensate for substantial unsolicited benefits could be based on the reasons that the beneficiary antecedently had to pursue the benefit through his own efforts.

But this possibility does not have broad implications for intellectual property ownership, I think, because it will be rare to find individuals with decisive reasons to act with the aim of developing particular intellectual goods. Ordinarily, the nature of the good or the path to its

\footnotetext{
${ }^{140}$ This example is inspired by Garrett Cullity's “Recalcitrant Fisherman” example, and I think my explanation of Pain in the Neck also explains what is intuitively objectionable about the behavior of Cullity's imagined fisherman. See Garrett Cullity, Moral Free Riding, 24 PHIL. \& PUB. AFF. 3, 11 (1995).
} 
creation will be too uncertain at the outset to provide decisive reasons to those who eventually benefit from it. The one range of potential exceptions would be cases—often categorized as "unfair competition" under the law-where one actor has a clear goal, such as publishing the day's news, and stands by and lets his rival, who has the very same goal, do all the work necessary for achieving it, only to copy the rival's product at the point it proves profitable. ${ }^{141}$ But the wrongfulness of this sort of behavior depends on the particular circumstances of the duty-holder and so stands far removed from the standard incidents of intellectual property, which impose obligations on virtually every non-owner regardless of his or her individual characteristics.

Once again, Locke does not furnish us with any explicit discussion of these issues. Locke does say, in apparently sweeping terms, that individuals have "no right to" "the benefit of another's Pains. ${ }^{142}$ In my view, he must mean this statement as the claim that individuals do not have a right that somebody else work for their benefit rather than the claim that it is wrongful for anybody to benefit freely from the work of another. His discussion of waste includes mention of cases where one can permissibly benefit from the work of another person and owe them nothing for it. ${ }^{143}$ And Locke also argues that one laborer's appropriation of some piece of land benefits the rest of humanity because the laborer can make do with much less developed land than he would have

${ }^{141}$ Cf. Int'l News Serv. v. Associated Press, 248 U.S. 215 (1918).

${ }^{142}$ LOCKE, supra note 1, bk. $2, \S 34$, at 291.

143 See id. bk. 2, § 38, at 295 ("[I]f either the Grass of his Inclosure rotted on the Ground, or the Fruit of his planting perished without gathering, and laying up, this part of the Earth, notwithstanding his Inclosure, was still to be looked on as Waste, and might be the Possession of any other."). 
needed of the undeveloped commons, ${ }^{144}$ but Locke does not suggest that everybody else ought to reward the laborer for this benefit. ${ }^{145}$ Therefore it is difficult to read Locke as committed to a general obligation to compensate for unsolicited benefits. And if my discussion in this section is sound, then Locke is right not to have such a commitment.

In this chapter, I have argued that Locke's labor theory of property does not furnish a natural rights-type justification for the standard incidents of intellectual property ownership, especially within the domain of copyright and patent law. As I have presented it, Locke's theory focuses on protecting a laborer from those who would interfere with his or her attempts to advance a legitimate interest in material gain. Copyright and patent ownership do much more than provide protection from this sort of interference. Central cases of trademark law, however, can be justified on these non-interference grounds. But individuals' interests in material gain are not the only interests implicated by intellectual property ownership, as we shall see in the following chapter, and so it is too early to conclude our discussion of natural rights-type justifications for intellectual property.

${ }^{144}$ Id. bk. 2, § 37, at 294 (“[H]e, that incloses Land and has a greater plenty of the conveniencys of life from ten acres, than he could have from an hundred left to Nature, may truly be said, to give ninety acres to Mankind.").

${ }^{145}$ Locke does say, however, that in Spain the productivity of the person who develops formerly unused land is so great that other "Inhabitants think themselves beholden to him," but he does not say the Spaniards' way of thinking is correct. Id. bk. 2, § 36, at 293. 


\section{NATURAL RIGHTS II: INTERESTS IN CONTROL}

The origin of ownership is difficult to comprehend.

- Immanuel Kant ${ }^{1}$

Kant, unlike Locke, unmistakably advanced an argument for copyright law, or at least part of it, though he did not employ the language of property or ownership. He argued that in the right circumstances, unauthorized reproduction of another's writing wrongs that person. In this chapter, I will examine Kant's discussion of copyright and argue that it justifies a rather limited amount of copyright protection, as well as some of trademark law. Before taking up Kant's intellectual property discussion, however, I will examine his account of physical property ownership as recently interpreted by Arthur Ripstein. On Ripstein’s interpretation, Kant's account of physical property ownership seems like it could readily be extended to justify intellectual property ownership. But I will contend that we should reject the view that Ripstein calls Kant's and not think it furnishes a natural rights-type justification for intellectual property ownership.

Kant's discussions of intellectual property and property expand our understanding of ownership in an important way. They show how ownership can serve important interests that are not simply reducible to Lockean interests in material gain. I am classifying these as interests in control, although much of the challenge ahead lies in specifying the kinds of control that are of

\footnotetext{
${ }^{1}$ B. Sharon Byrd \& Joachim Hruschka, The Natural Law Duty to Recognize Private Property Ownership: Kant's Theory of Property in his Doctrine of Right, 56 U. TORONTO L.J. 218, 218 (2006) (translating IMMANUEL KanT, Naturrecht Feyerabend, 27 GeSAMMELTE SCHRIFTEN 1319, 1343 (1979)).
} 
greatest interest to individuals. In my view, aspects of property and intellectual property ownership serve our interests in having control over what we do, since being able to use physical objects and ideas and information as we please increases our opportunities to pursue a wide variety of goals. Part of having control over what we do, moreover, is having a reputation that accurately reflects the what we have chosen to do in the public's view, and having an accurate reputation of this sort can reasonably be valued apart from its ability to bring us material gain. Ripstein likewise emphasizes our interests in controlling what we do-although he might object to thinking about these issues in terms of "interests" - but in addition he thinks we have quite strong interests in controlling bow our property is used that outstrip our interests in being able to pursue our goals. In the next section, I will question whether we indeed have such a strong interest in controlling our property.

\subsection{KANTIAN PROPERTY}

Kant's principal discussion of property rights occurs in The Metaphysics of Moralsspecifically in the work's first half, Metaphysical First Principles of the Doctrine of Right, known as the Rechtslebre or "Doctrine of Right" for short, ${ }^{3}$ where he presents his theory of private and public law. The Rechtslebre is not Western philosophy's most approachable text, and it is no surprise to anyone who has attempted to understand it that the Recbtslebre has been the subject of numerous scholarly interpretations. Rather than attempt to add to this literature, I will focus on Ripstein's

2 See Arthur Ripstein, Force and Freedom: Kant's Legal and Political Philosophy 34 (2009) (explaining how his understanding of Kantian freedom does not invoke a general interest in being able to set and pursue one's own purposes).

${ }^{3}$ Alternatively, this work is occasionally called Metaphysical Elements of Justice or Metaphysical Principles of Justice. 
particular interpretation, which is both accessible and relevant to the subject of intellectual property. Setting aside the question of whether Ripstein's interpretation is faithful to Kant, I will argue that it supports several of the standard incidents of intellectual property ownership if it is defensible on its own merits. But I will further argue that on the merits one ought not to accept it as a plausible account of physical property ownership. In the end, then, Ripstein's version of Kant does not provide a plausible natural rights-type justification for the standard incidents of intellectual property.

Like the Rechtslebre itself, Ripstein's discussion begins with the definition of right action found in Kant's "Universal Principle of Right": “Any action is right if it can coexist with everyone's freedom in accordance with a universal law, or if on its maxim the freedom of choice of each can coexist with everyone's freedom in accordance with a universal law." ${ }^{\prime 4}$ To present Kant's argument on behalf of property rights, ${ }^{5}$ Ripstein makes use of an implication of the Universal Principle of Right, which is that hinder another person's action when that action is compatible with everybody's freedom wrongs that person. ${ }^{6}$ Because a person can use external objects—that is, things

\footnotetext{
${ }^{4}$ Immanuel Kant, The Metaphysics of Morals 6:230 (1797), reprinted in Practical Philosophy 353, 387 (Mary J. Gregor ed. \& trans., Cambridge Univ. Press 1996).

${ }^{5}$ On Kant's account, property rights are, as Ripstein emphasizes, just a special case of rights to "external objects of choice, that is, those things other than your own person that you can use in setting and pursuing your purposes." RIPSTEIN, supra note 2, at 57. Unlike the nonacquired right one has with respect to one's own person, rights to external objects of choice are acquired. Other examples of Kantian acquired rights include contractual rights and rights parents have over their children. Although parts of Kant's argument and Ripstein's interpretation of it are generalizable insofar as they apply to any acquired rights, I will discuss the particularized version that applies to property.
}

\footnotetext{
${ }^{6}$ KANT, supra note 4, 6:230-231, at 387 ("If then my action or my condition generally can coexist with the freedom of everyone in accordance with a universal law, whoever hinders me in it does me wrong; for this hindrance (resistance) cannot coexist with freedom in accordance with a universal law.").
} 
apart from his own person-to set and pursue his purposes, ${ }^{7}$ the Universal Principle of Right entails that he is entitled to do so if (and only if) his use of those external objects can coexist with the freedom of everybody in accordance with a universal law. ${ }^{8}$ The key question, then, is whether one person's ownership of external objects, in pursuit of her own purposes, is compatible with everybody's freedom. Ripstein argues that it can be:

No other person is wronged by another's having an object subject to his or her choice. The freedom of others would only be compromised if one person's having a proprietary ... right deprived some other person of something he or she already had. ... So any restrictions on the possibility of a person having objects as her own would restrict one person's purposiveness for the sake of something other than freedom .... That is, they would limit freedom on the basis of something other than its own conditions.'

In claiming that appropriation does not deprive anyone of what she already had, Ripstein seems to be invoking Kant's assumption of common possession - that is, that the whole world is initially possessed by everyone in common. ${ }^{10}$ Like Locke, Kant's starting point is a world in which no one yet has any claim to the exclusive use of particular resources. And so from the common possession assumption and the Universal Principle of Right, Ripstein reads Kant to infer that some form of private ownership must be recognized because it expands human freedom without violating

\footnotetext{
${ }^{7}$ According to Ripstein, "Whether and which things other than your person can be used to set and pursue purposes is, at least in part, contingent on the particular features of finite purposive beings." RIPSTEIN, supra note 2, at 58.

${ }^{8}$ See id. at 62.

${ }^{9}$ Id. at 63-64; see also id. at 62 ("Kant argues that the exercise of acquired rights is consistent with the freedom of others, because it never deprives another person of something that person already has.").

${ }^{10} \mathrm{KANT}$, supra note 4, 6:261, at 413.
} 
anyone's freedom: property ownership enables individuals to set and pursue their own purposes using external objects in a manner consistent with everyone's purposiveness. ${ }^{11}$

This argument seeks to justify property ownership in the abstract, but without yet revealing how someone acquires property in the first place or what specific rights property ownership includes. On the subject of acquiring property, Ripstein says that Kant's account of acquisition is "boring because the only factual precondition of rightful acquisition of an unowned object is empirical [i.e. physical] possession of that object,"12 which Ripstein understands as including communication of a public sign that the person taking possession is doing so in order to have the object as his or her own property. ${ }^{13}$ Ripstein contrasts this account of acquisition with Locke's, which Ripstein unfortunately assumes requires either toil or some improvement of the object being acquired. ${ }^{14}$ The non-"factual" precondition of Kantian acquisition is what Ripstein calls "a broader

${ }^{11}$ RIPSTEIN, supra note 2, at 58.

${ }^{12} I d$. at 104 .

${ }^{13}$ See id. at $104-05$.

${ }^{14} I d$. at $98-101$. Ripstein seems to me to exaggerate the opposition between Kant and Locke here. He is right that Kant explicitly criticizes one version of a labor theory of property that sees toil as the basis for rightful acquisition:

The first working, enclosing, or, in general, transforming of a piece of land can furnish no title of acquisition to it; that is, possession of an accident can provide no basis for rightful possession of the substance. What is mine or yours must instead be derived from ownership of the substance in accordance with this rule (accessorium sequitur suum principale), and whoever expends his labor on land that was not already his has lost his pains and toil to who was first.

KANT, supra note 4, 6:268-69, at 419-20. But I am not convinced that what Kant says here is incompatible with Locke's own labor theory. Recall, from Chapter 2, that Locke's conception of labor is simply intentional action aimed at deriving any of the necessities or conveniences of life, and hence does not require toil on the part of the laborer. I am not even convinced that Kant is responding directly to Locke, whose political philosophy was mostly ignored in $18^{\text {th }}$ century Continental Europe. See, e.g., Klaus P. Fischer, Jobn Locke in the German Enlightenment: An Interpretation, 36 J. Hist. IDEAS 431, 441 (1975). Rather, I suspect that Kant is endorsing and elaborating on Hume's criticism of an implausible toil-account of acquisition. See David Hume, A TREatise of Human Nature bk. 3, pt. II, § 3, at 505 
context of public right." ${ }^{15}$ Through my acquisition of an external object, Ripstein claims, I impose new duties (not to use what I have acquired) on the rest of the world "only if my choice is exercised in light of an (ideally) publicly conferred power to appropriate." ${ }^{16}$ The public authority confers this power to acquire property "in the name of everyone" ${ }^{17}$ but is not traceable to any historic conferral of consent, or hypothetical consent based on what any prudent person would agree to. ${ }^{18}$ The ultimate result, on Ripstein's view, is that there is no duty not to interfere with others' acquisitions unless everyone, through an omnilateral will, authorizes unilateral appropriation of unowned objects. ${ }^{19}$

Once an authoritative private property system exists, the next question is about the scope of the rights and duties it recognizes. According to Ripstein, property rights protect an owner from

n.1 (L.A. Selby-Bigge \& P.H. Nidditch eds., Oxford Univ. Press 2d ed. 1978) (1739-1740). As Hume notes, a labor theory of property that does not focus on toil is not very remote from a possession theory. $I d$.

${ }^{15}$ RIPSTEIN, supra note 2, at 97.

${ }^{16} I d$. at 154 .

${ }^{17} I d$.

${ }^{18} I d$. at $155-56$.

${ }^{19} I d$. at 157-60; see also id. at 26 ("In a state of nature, a person does others no wrong by taking from them ...."). This aspect of Ripstein's interpretation seems in some tension with what Kant says, for Kant certainly believes in acquisition in anticipation of the civil condition: "[S]omething external can be originally acquired only in conformity with the idea of a civil condition, that is, with a view to it and to its being brought about, but prior to its realization (for otherwise acquisition would be derived)." KANT, supra note 4, 6:264, at 416. As far as I can see, Kant argues that individuals have both a duty to enter into a civil condition with others and some sort of duty not to interfere with the acquisitions of those who have acquired external objects and are ready to enter into a civil condition. See id. 6:256-57, at 410; 6:312-13, at 456; $c$. B. SHARON BYRD \& JOACHIM HRUSCHKA, KANT's DOCTRINE OF RIGHT: A COMMENTARY 118 (2010) (discussing a pre-civil condition duty not "to prevent another person from acquiring an unowned and unused object, not because the first person wants to acquire it as his own, but because he wants to prevent the second person, or anyone else, from acquiring the object as her own."). But this is a difficult interpretive question. 
two sorts of actions that interfere with her freedom: first, other people may not deprive a property owner of her ability to set and pursue her own purposes using what she owns-for example, by taking or damaging her property; second, others may not use private property that is not theirs to set and pursue their own purposes without the owner's consent. ${ }^{20}$ Both of these rights protect the owner's control of her property, although in different ways. The first right comes quite close to the Lockean protection against interference with labor, although having control over one's property serves interests beyond material gain—or, as Locke would say, beyond obtaining the necessities and conveniences of life-such as interests in personal privacy. The second right gives owners a much greater degree of control over what they own, for it prohibits any non-owner from using property to pursue his own ends regardless of the effect on the owner's pursuit of the ends she sets for herself.

Thus, for Ripstein, property rights go significantly further than rights against interference, as several of his examples illustrate:

Suppose that I break into your home and eat dinner at your table while you are out. (I bring my own food, and clean up after myself.) ... I use your property in pursuit of my ends, an end that you do not share. In so doing, I wrong you. ... [T] he wrong in question ... is depriving you of your freedom to be the one who sets the ends that you will pursue, or that will be pursued with your goods. I enlist you or your means in support of ends you do not share.... ${ }^{21}$

[I] I manage to enlist you in support of my projects without your consent, I must surrender to you any gains I make as a result. I must do so because the use I made of your right to set your own ends must be treated as an embodiment of your freedom, and so given back to you. So, for example, if you invite tourists to explore

\footnotetext{
${ }^{20}$ RIPSTEIN, supra note 2, at 67.

${ }^{21}$ Id. at 70; cf. Arthur Ripstein, Beyond the Harm Principle, 34 PHIL. \& PUB. AfF. 215, 218 (2006) (giving an example of a harmless trespasser who takes an unauthorized nap in a homeowner's bed).
} 
the caves under your land, and lead them underground to the caves under mine, you must disgorge any gain you received from the use of my caves, even if I could not have capitalized on them on my own .... ${ }^{22}$

On the Lockean account I defended in the previous chapter, neither example involves wrongdoing (except perhaps if positive law says otherwise) because the non-owner is not interfering with the owner's labor in either case. The way these two examples are presented, the owner's ability to use her property in pursuit of whatever ends she has set for herself is not actually impeded. In the first example, though, there is a non-negligible risk of interference, since if the owner changes her mind and returns home to a messy dining room, she may not be able to use what she owns as she would like. But Ripstein does not seem to rest his case on the possibility of harm. On his reading of Kant, trespasses are wrongs in the same way as unauthorized touchings of another individual's body are wrongs, regardless of the harm they might threaten:

Suppose that you are opposed to the fluoridation of teeth on what you believe to be health-related grounds. You are mistaken about this, but committed to campaigning against fluoridation. As your dentist, I use the opportunity created by filling one of your (many) cavities to surreptitiously fluoridate your teeth, pleased to have advanced the cause of dental health, and privately taking delight in doing so on you, the vocal opponent of fluoridation. In this example, I don't harm you, and there is even a sense in which I benefit you. I still wrong you because I draw you into a purpose that you did not choose. You remain free to use your powers to set and pursue other purposes. But part of being free to use your powers to set and pursue your own purposes is having a veto on the purposes you will pursue. . . When I usurp your powers, I violate your independence precisely because I deprive you of that veto. ${ }^{23}$

\footnotetext{
${ }^{22}$ RIPSTEIN, supra note 2 , at $82-83$.

${ }^{23}$ Id. at 44; accord Ripstein, supra note 21, at 234-35.
} 
When someone makes unauthorized use of another person's body or property, Ripstein views the conduct as wrongful simply because it violates the wronged party's independence and sovereignty. ${ }^{24}$ That is, it prevents the wronged party from being her own master by forcing her to pursue ends that she has not chosen. ${ }^{25}$

Let us set aside, for a moment, whether Ripstein's treatment of these examples is convincing and consider the implications for intellectual property rights. A huge number of intellectual property infringement cases—and all the central ones—can be characterized as using another person's "goods," "means," or "powers" for ends she did not authorize, and hence would seem to be presumptively wrongful on Ripstein's account. If I put your logo on my wares to convince consumers that I am you, I am quite obviously using your trademark for purposes you do not share. ${ }^{26}$ Likewise if I take your invention and, without your permission, make my own versions of it to share with others or to keep for myself or if I adapt your painting into a three-dimensional sculpture, which you might not like. The first three standard incidents of intellectual property ownership - the excluding privileges to embody, develop, and distribute-all clearly protect against using intellectual property for purposes its owners do not share. ${ }^{27}$ And the fourth standard

${ }^{24}$ See, e.g., RIPSTEIN, supra note 2 , at 47, 68.

${ }^{25}$ See, e.g., id. at 22, 45, 70, 77.

${ }^{26}$ Note that beyond this sort of trademark infringement, which is grounded in consumer confusion about the source of a product, a Ripsteinian case for trademark ownership would also condemn so-called sponsorship confusion. Thus, if I name my Little League team after a professional baseball team, I have used the latter's name for ends it has not authorized and thus have wronged it, even if no one would believe that my team was made up of members of its professional namesake.

${ }^{27}$ U.S. law, however, does not exactly embody this idealized picture of full intellectual property ownership, for it limits owners' legal ability to block specific unauthorized uses of their intellectual property, for instance, through doctrines of exhaustion and fair use. 
incident—-powers to license and assign—can be seen as acknowledging consent's ability, on Ripstein's view, to make the use of another's means permissible. ${ }^{28}$ Thus Ripstein's reading of Kant seems to suggest that intellectual property rights are justified, prima facie, on the very same moral grounds as physical property rights. ${ }^{29}$

Ripstein might object, however, to my assumption that trademarks, copyrights, and patents are, like land and chattels, the kind of things that can be the subject of justified ownership. After all and as Ripstein notes, Kant does not use the "property" label in his own discussion of intellectual property rights. ${ }^{30}$ Yet I do not believe Ripstein is able to disavow his account's apparent implications for intellectual property so easily. For the very same argument he gave to justify ownership of physical objects ${ }^{31}$ applies equally well in the case of intellectual property. Here is how that argument would go:

P1. To hinder another person's action when that action is compatible with everybody's freedom is to wrong that person. (from Universal Principle of Right)

P2. A person is entitled to use a copyrighted work, patented invention, or trademarked logo of his own making to set and pursue his purposes if (and only if) his use of those things can coexist with the freedom of everybody in accordance with a universal law. (from P1)

${ }^{28}$ See, e.g., RIPSTEIN, supra note 2, at 70.

${ }^{29}$ Robert Merges has himself argued that Kant's theory of property rights extends to intellectual goods. See Robert P. MERges, Justifying InTELlectual Property 75-78 (2011). It is clear that Merges's understanding of Kant's property theory is not the same as Ripstein's, but I will not address Merges's discussion here.

\footnotetext{
${ }^{30}$ See RipsteIn, supra note 2, at 95 n.13.

${ }^{31}$ See supra notes 6-11 and accompanying text.
} 
P3. An action can coexist with everybody's freedom in accordance with a universal law if it does not deprive another person of something she already had.

P4. A person who uses a copyrighted work, patented invention, or trademarked logo of his own making to set and pursue his purposes does not deprive another person of something she already had.

C1. Therefore use of a copyrighted work, patented invention, or trademarked logo of one's own making to set and pursue one's purposes can coexist with everybody's freedom in accordance with a universal law. (from P3, P4)

C2. Therefore a person is entitled to use a copyrighted work, patented invention, or trademarked logo of his own making to set and pursue his purposes. (from P2, C1)

The upshot of this argument would be that the sorts of things an intellectual property owner owns can be among a person's means, in Ripstein's sense, and so using them without that person's consent would wrongfully violate his or her sovereignty. Ripstein is explicitly committed to all of these premises except $\mathrm{P} 4$, but it is hard to believe that $\mathrm{P} 4$ would be objectionable if Ripstein's version-which holds that having tangible objects subject to one's choice does not in itself deprive anyone of something they had-is not. ${ }^{32}$ So, by Ripstein's own lights, private ownership of intellectual goods would seem justified because it extends external freedom in a manner consistent with everyone else's external freedom. It must be possible, therefore, for intellectual property to be among the means that an individual rightfully uses to set and pursue her ends. As much as with

\footnotetext{
${ }^{32}$ On the other hand, if Ripstein's version of $\mathrm{P} 4$ is just an alternative way of assuming common initial possession of the earth's resources, one might doubt that Ripstein would accept the intellectual property version of P4 that I am using here. For, as the last chapter noted, it seems odd to say that a copyrighted work is initially possessed by everyone in common. But much of the work Kant's common possession assumption does in Ripstein's argument is to explain why the person who first acquires some object has not wronged anyone else: no one has a claim to the exclusive use of that object at the outset. See also Christine M. Korsgaard, Kantian Ethics, Animals, and the Law, 33 OXFord J. LEGAL STUD. 629, 646 (2013) (advancing a similar interpretation of Kant's common possession assumption). If this claim is true in the physical property context, it seems a fortiori true with respect to intellectual property. Surely no one has a better claim to exclusive use of a book, invention, or logo than its creator.
} 
any of her other means, then, no one else is permitted to use her intellectual property for ends she has not set for herself. And just as with physical property, this restriction holds regardless of whether others could use that intellectual property in ways that do not conflict with the owner's use of it.

It remains to be seen, however, whether Ripstein's two preconditions of rightful ownership of specific intellectual goods are met. Recall that for Ripstein, "empirical possession" of an object is the only factual precondition for taking ownership of it. ${ }^{33}$ Now, while it is true that one cannot physically possess something as intangible as intellectual property, Ripstein identifies empirical possession as the factual precondition of rightful acquisition simply because that is the manner in which one brings unowned physical objects under one's control. Ripstein himself says that the essential fact here is simply that the object be brought "under [the owner's] control, so that she can now decide how to use it. ${ }^{\not 34}$ And it would seem that the person who creates an invention or copyrightable text does have it under her control, at least at the moment of creation. So the first precondition is satisfied in the case of intellectual property. It is less clear, perhaps, that the duties generated under a system of intellectual property ownership are necessarily authorized by an omnilateral will. On Ripstein's conception, the omnilateral authorization of acquisition in the case of regular, non-intellectual property is not optional or otherwise contingent: the omnilateral will

\footnotetext{
${ }^{33}$ See supra note $12-13$ and accompanying text.

${ }^{34}$ RiPSTEIN, supra note 2, at 104.
} 
must authorize acquisition, lest it limit human purposiveness. ${ }^{35}$ Yet Ripstein does believe that the necessary sort of omnilateral authorization can include some restrictions on privatization-by dedicating certain resources as inherently public property, for instance, or conditioning acquisition on certain recordkeeping procedures-although he does not specify what principles determine which restrictions are possible beyond noting that they must be compatible "with each person's entitlement to have external objects of choice as his or her own." ${ }^{36}$ And it is possible that the omnilateral authorization to appropriate is limited to physical resources because physical resources are special in some way. ${ }^{37}$ It might be possible to preclude a Ripsteinian justification of intellectual property on the basis of what the omnilateral will authorizes, but Ripstein does not tell us how to do that.

Let us then proceed on the assumption that Ripstein's principles would, if sound, furnish a natural rights-based justification for the standard incidents of intellectual property ownership. I do not believe Ripstein's principles are sound, even as they are meant to apply in the case of regular tangible property. He does seem to me correct in saying that it is wrong to perform medical

${ }^{35} \mathrm{Id}$. at 155 ("[A] uthorizing acquisition is not a discretionary purpose that a public authority might decide about based on some assessment of the desirable consequences or balance of benefits and burdens that will result. A public authority could not be entitled to prohibit all acquisition ....").

${ }^{36} I d$.

${ }^{37}$ As Kant tells it, the omnilateral authorization occurs because we possess the earth in common and seek to use it for our own purposes but cannot do so without coming into conflict with one another. See KaNT, supra note 4, 6:267, at 418; see also Byrd \& Hruschka, supra note 1, at 220-21 ("We are part of an original community of the land and the things upon it in virtue of our being together with everyone else on a limited sphere from which we cannot escape and must not be forcibly removed.... The a priori necessarily united will of all recognizes and secures individual property ownership rights to avoid conflict in the use of external objects of choice."). One might sensibly question whether conflict in the use of objects of intellectual property is similarly unavoidable. If Ripstein wanted to distinguish intellectual property from physical property, it seems to me that this is the most promising place to do draw the distinction. 
procedures without informed consent because the patient has a right to be sovereign over his or her own body. ${ }^{38}$ But that does not mean that unauthorized use of someone's physical property contravenes his or her sovereignty in a parallel way. For although a person's possessions are like his or her body inasmuch as they furnish means for pursuing his or her ends in this world, our interests in having control over our own bodies seem quite different from our interests in controlling our possessions. As Larissa Katz notes, the trespasser who harmlessly uses my belongings does indeed subject them to his choice. "But in so doing," she asks, "does he subject $m e$ to his choice in the same way that the doctor, in using his patient's body without her consent, subjects her to his choice?"39 Katz does not explicitly answer this question, although she seems doubtful. ${ }^{40}$ I think the answer is clear. Someone who uses another's property without authorization does not subject the owner to his choice, at least not for that reason alone. He may do so, for instance, if his trespass inhibits the owner's actions or uncovers some private facts that the owner wished to keep hidden. But not every unauthorized use of another's property is "forcing a person to act for an end that she does not share. ${ }^{41}$ To say that someone who, without my permission, uses my dining room in order to take a meal somehow forces me to promote her nourishment is to assign me too little control over my actions. Similarly, the carjacker who subsequently runs off with

\footnotetext{
${ }^{38}$ This conclusion is even more plausible in the example, which Ripstein occasionally wields against harm-based views of wronging, of someone who rapes a completely unconscious victim knowing that the victim will never learn of the crime nor suffer any harm. See RIPSTEIN, supra note 2, at 92 n.9.

${ }^{39}$ Larissa Katz, Ownership and Social Solidarity: A Kantian Alternative, 17 LEGAL THEORY 119, 138 (2011).

${ }^{40} I d$. at 139.

${ }^{41}$ RIPSTEIN, supra note 2, at 70.
} 
my vehicle to rob a bank does not seem to implicate $m e$ in the bank robbery in the way he would if he coerced me, at gunpoint, to be his driver. I indeed can act through my possessions, but others cannot make my possessions act on my behalf for the sake of ends I have not chosen.

Moreover, even when an owner has affirmatively decided that his property must not be used in a particular way, that does not seem to settle the question whether others are permitted to go against the owner's decision. ${ }^{42}$ Imagine an architect-sculptor who first thinks to decorate the capital of a structural column with acanthus leaves and uses his design in his own home. Because he does not want anyone else to copy his design or even to admire it without giving him something valuable in return, he decides not to incorporate his Corinthian column on his residence's exterior, where it would be in others' plain view, but only behind opaque walls beyond the permitted access of non-owners. In this manner he sets and defends his agenda or ends-not only for his home or for the physical columns that embody his design, but for the design itself. Suppose further that while this individual is traveling overseas, a natural disaster strikes near his home and brings down several walls, exposing his undamaged columns to the public eye. Would those who knew of the architect-sculptor's aims be obligated not to let their gaze linger on the

\footnotetext{
${ }^{42}$ One admittedly extreme example supporting this claim is Joel Feinberg's famous example of the mountain hiker who breaks into an unoccupied privately owned cabin to take refuge in a life-threatening snowstorm. See Joel Feinberg, Voluntary Euthanasia and the Inalienable Right to Life, 7 PHIL. \& PUB. AFF. 93, 102 (1978). As Feinberg rightly observes, this action, which would otherwise constitute trespass, is wholly justified. And U.S. tort law agrees. See, e.g., Vincent v. Lake Erie Transp. Co., 124 N.W. 221 (Minn. 1910); Ploof v. Putnam, 71 A. 188 (Vt. 1908). The hiker's action would undoubtedly still be permissible even if the cabin owner had expressly denied permission to anyone seeking use of the unoccupied cabin in an emergency, for example, by posting a sign saying as much. $C f$. Gerald Gaus, Property, in The OXFord Handbook of Political Philosophy 93, 102-03 (David Estlund ed., 2012) (imagining that the cabin owner had posted a sign saying, "Can you use this cabin in case of emergency? No!"). In this sort of case, the fact that the non-owner is disregarding the owner's decision makes no difference to the permissibility of the nonowner's actions.
} 
columns in deference to the owner's agenda and ends? I do not see why they would be, unless the owner had some special sort of privacy interest in his artwork. And maybe Ripstein would agree. After all, he states that no one can have a right under a universal law that others not look at her "because embodied and motile persons can only avoid bumping into each other by looking where they are going, and so sometimes at each other. ${ }^{43}$ It is not clear, however, what would stand in the way of a universal law prohibiting others from peering inside one's vacant home. Therefore this line of response might not account for the permissibility of my imagined unauthorized Corinthian column viewing. Elsewhere, Ripstein assumes that it would be permissible for a hypothetical passerby to take visual delight in the beautiful flowers a homeowner had planted without having to seek the latter's permission. ${ }^{44}$ Doing so would presumably be making use of the homeowner's property for ends he had not authorized ${ }^{45}$ - we may even imagine that he has posted a sign directing those who stop to stare at his flowers to place a quarter in a collection box. Ripstein does not explain why he thinks looking at a homeowner's flowers is permissible, but perhaps it is enough that the passerby is on a public road or sidewalk, where one presumes the passerby is permitted to be. ${ }^{46}$ If that is what renders the unauthorized use of the gardener's handiwork

${ }^{43}$ RIPSTEIN, supra note 2, at 46.

${ }^{44}$ Ripstein, supra note 21, at 221.

${ }^{45}$ If it seems like too much of a stretch to describe this act as "making use of" the flowers, imagine that the passerby snaps a digital photo of one of the flowers and sets the image as her computer wallpaper.

${ }^{46}$ My evidence for this interpretation includes another example Ripstein sometimes uses: it would be permissible, he says, for one neighbor to grow mushrooms in shade cast by another neighbor's fence. See RIPSTEIN, supra note 2, at 79,102 . Here too it looks like the first neighbor is making use of the other's property for unauthorized ends, but one suspects that Ripstein does not condemn this unauthorized use as impermissible because it occurs on the first neighbor's own property. The verdict of permissibility seems quite right, but it raises further questions about Ripstein's account. What principles of Kantian external freedom, for instance, establish that the caves under one's land are part of 
permissible, however, then it would seem equally to permit not only gazing upon the architectsculptor's Corinthian columns but also embodying their design in one's own columns or developing the design further into a Corinthian-Ionic composite column. And so the Ripsteinian justification for intellectual property ownership's standard incidents would have a major loophole.

These points all lead me to conclude that intellectual property's standard incidents are not justified along the same lines as Ripstein argues that regular property rights are. His general claim that unauthorized use of someone's property wrongfully usurps her powers by forcing her to pursue ends she had not set for herself, and thereby undermines her ability to be her own master, strikes me as implausible. And if we accepted it without further qualification, we would be left with very strong property rights and results that are hard to accept—such as the result that unauthorized viewing of a neighbor's property is impermissible — and that even Ripstein appears unwilling to accept. If we qualify the view to avoid these severe results, we weaken the account's ability to ground strong intellectual property rights. However we proceed, Ripstein's Kantianism does not provide a convincing natural rights-type justification for the standard incidents of intellectual property ownership.

\subsection{Kantian Intellectual Property}

Kant's discussion of intellectual property rights is very different from Ripstein's discussion of physical property rights. For Kant, intellectual property rights derive not from a broad right to

one's property even if one cannot access them, see id. at 83 , while the territory covered by a horticulturally valuable shadow cast by one's fence is not? 
control how one's external means are used, but from a much narrower right to be the only person who speaks in one's name. Indeed, what Kant says about some specific examples might even be thought to imply that he does not believe that the broader Ripsteinian right applies to intellectual goods. For instance, he claims that someone who makes an unauthorized abridgement or translation of a book-someone who could well be using the book to pursue ends the author has not herself set, especially if the abridgement or translation is unfaithful to the author's intentions-does nothing wrong provided he indicates that the author is not responsible for the modifications. ${ }^{47}$ And Kant even claims that reproducing physical works of art requires no permission whatever. ${ }^{48}$ But whatever the implications of these claims for Ripstein's argument, Kant's remarks on intellectual property deserve close attention on their own terms.

The basics of that argument can be found in the Rechtslebre-though in the part of it that addresses contracts, or transferring "what belongs to another," rather than the part that addresses property rights themselves. ${ }^{49}$ That is because the right to speak in one's own name, on which Kant's account of copyright is based, is conceived of as the right a person has to appoint agents to carry out his affairs and the concomitant right that others not pass themselves off as his appointed agent when in fact he has not appointed them such. ${ }^{50}$ An author, through the books she writes, speaks to the public in her own name, and the publisher of her work is merely her agent, a

\footnotetext{
47 See Immanuel Kant, On the Wrongfulness of Unauthorized Publication of Books 8:86-87 (1785), reprinted in Practical Philosophy, supra note 4, at 23, 35.

${ }^{48}$ Id. 8:85-86, at 34 .

${ }^{49} \mathrm{KANT}$, supra note 4, 6:286, at 434 .

${ }^{50}$ Cf. id. 6:285-86, at 433 (discussing agency contracts and mandates generally).
} 
medium through which she speaks. ${ }^{51}$ Thus any publisher, on Kant's view, speaks in the name of the author whose work he publishes and not in his own name, whether or not he is authorized. ${ }^{52}$ But, Kant claims, one cannot be entitled to speak in another's name as though one were her duly empowered agent if one does not have authorization or a "mandate" from her, and so unauthorized publication of books is impermissible. ${ }^{53}$ As it happens, Kant articulated this line of thought in more detail in an essay that appeared twelve years before the Rechtslebre, entitled On the Wrongfulness of Unauthorized Publication of Books. ${ }^{54}$ And we can better understand Kant's Rechtslebre argument if we turn to that essay.

Kant's views about copyright are presented through two syllogisms in the essay. The first is a positive argument for the impermissibility of unauthorized publication, similar to the brief Rechtslebre version that we just saw; the second is a negative argument critiquing a possible case for unauthorized publication's permissibility. The first syllogism's major premise is that anyone “who carries on another's affairs in his name but against his will" must compensate him for any losses and hand over to him or his designated agent all profits. ${ }^{55}$ And its minor premise is that unauthorized publishers do carry on the author's affair in his name but against his will. ${ }^{56}$ The

${ }^{51}$ Id. 6:289, at 437.

${ }^{52} I d$.

${ }^{53} I d$. Kant also says that the unauthorized publisher steals profits from the legitimate publisher who has been authorized by the author to speak in her name. $I d$.

\footnotetext{
${ }^{54}$ Kant, supra note 47.

${ }^{55}$ Id. 8:79-80, at 29.

${ }^{56} I d .8: 80$, at 29.
} 
second syllogism responds to a potential objection: perhaps the author who willingly sells copies of his book to the public, transferring ownership of a tangible thing (namely each individual copy), has given the legitimate owners of those copies a property-based entitlement to use them as they please, including by duplicating them. ${ }^{57}$ Kant's major premise in response is that ownership of tangible property, by itself, never generates a "positive right" obligating somebody else to do something for the owner. ${ }^{58}$ His minor premise here is that the copy-owner's entitlement to publish newly duplicated copies would be a positive right against the author, and so he concludes that copy-ownership as such does not implicitly confer on the copy-owner an entitlement to reproduce the work it embodies. ${ }^{59}$

These arguments do rather seem to support the standard incident of intellectual property ownership that I have been calling the excluding privilege to embody, at least for intellectual goods that have the form of copyrightable speech. Kant seems to be saying that unauthorized embodiment of a book appears to carry on the author's affairs in his name without his leave to do so and even, perhaps, against his will. And it is no defense that the person making the unauthorized embodiment owned another embodiment of the book that served as his model. These are the conclusions one reaches on a superficial reading of what Kant says. ${ }^{60}$ But I think this

\footnotetext{
${ }^{57}$ See id. 8:82, at $31-32$.

${ }^{58}$ Id. 8:83, at 32 .

${ }^{59} I d$.

${ }^{60}$ See, e.g., Anne Barron, Kant, Copyright and Communicative Freedom, 31 LAw \& PHIL. 1, 31-33 (2012); Neil Netanel, Alienability Restrictions and the Enbancement of Author Autonomy in United States and Continental Copyright Law, 12 CARDOZO ARTS \& ENT. L.J. 1, 17-18 (1994); Kim Treiger-Bar-Am, Kant on Copyright: Rights of Transformative Authorship, 25 CARDOZO ARTS \& ENT. L.J. 1059, 1076-77 (2008). Treiger-Bar-Am, however, argues that Kant's reasoning actually extends beyond its face value to justify an excluding privilege to embody other artistic
} 
interpretation is too quick and ultimately ought to be rejected. Consider some of the problems Kant would face if this were indeed his view.

Kant's first major premise seems essentially correct: someone who falsely pretends to be the representative of someone must hand over the gains he receives or compensate for any harm he inflicts either on the person whose representative he falsely pretends to be or on that person's true representative. ${ }^{61}$ But the accompanying minor premise is open to dispute, at least on the reading we are considering. It seems to be no necessary feature of unauthorized embodiment of a copyrighted text work that the person who is engaged in the unauthorized copying is pretending to be the true author's chosen representative. Rebecca Tushnet has identified numerous examples of unauthorized copyists whose deliberate copying of another's words says something in their own voices as well: the dissenting Supreme Court Justice who voices his opposition to constitutional protection for flag burning by reproducing a Civil War-era poem in its entirety; ${ }^{62}$ the person who reproduces a newspaper article as a way of drawing another's attention to information she finds significant; ${ }^{63}$ and the individual who demonstrates commitment to a group or ideal by reciting the

works besides speech. See Treiger-Bar-Am, supra, at 1085. She mainly defends this position (1) by claiming that the creation of non-verbal artwork can also constitute an act of expression between the creator and the public, and (2) by pointing out that advances in technology have made it easy today to create non-transformative, near-exact reproductions of non-verbal artwork whereas in Kant's time such reproduction was only possible for the printed works that attract Kant's attention. Id. at 1086-90.

${ }^{61}$ I deliberately set aside the question of whether we should think he owes this payment to the author, his true representative, or both.

${ }^{62}$ Rebecca Tushnet, Copy This Essay: How Fair Use Doctrine Harms Free Speech and How Copying Serves It, 114 YALE L.J. 535, 573 (2004) (citing Texas v. Johnson, 491 U.S. 397, 424-25 (1989) (Rehnquist, C.J., dissenting)).

${ }^{63}$ See id. at 578. 
specific words of an official pledge or oath. ${ }^{64}$ The Supreme Court has told us, in vaguely Kantian language, "The First Amendment securely protects the freedom to make—or decline to makeone's own speech; it bears less heavily when speakers assert the right to make other people's speeches. ${ }^{65}$ But, as Tushnet points out, that statement cannot possibly be true, for the New York Times rightly receives constitutional protection of its own when it chooses to print an independent author's editorial or government-written reports that cause political embarrassment. ${ }^{66}$ So if Kant's defense of copyright excludes the possibility of copying someone else's speech and delivering it in one's own voice, we ought not to accept it.

But we need not read Kant in any such way. For him, a publisher is someone who prints another's speech while effectively saying something like the following to the public:

Through me a writer will by means of letters have you informed of this or that, instruct you, and so forth. I am not responsible for anything, not even for the freedom which the author assumes to speak publicly through me: I am only the medium by which it reaches you. ${ }^{67}$

On Kant's conception, publishers as such are thought to conform to a model exemplified by Amazon Kindle's e-book direct publication service: anyone can publish their speeches through Amazon, which plays no role in selection or promotion. ${ }^{68}$ This model excludes many of the most

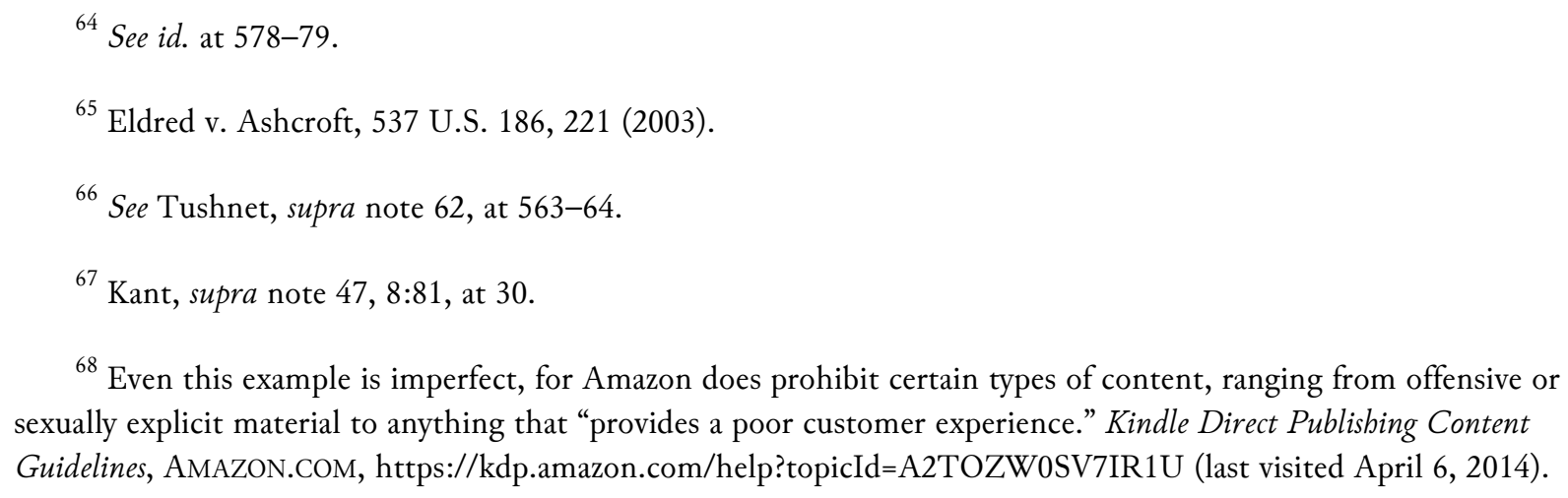


prominent entities that we think of as publishers today, whose prominence partly depends on their perceived ability to identify promising works and who take responsibility, to some degree, for what they print. Many copyists say something other than what Kant's publishers are saying-such as that the author's work is interesting, important, or of a high quality. They seem to be untouched by Kant's first syllogism because they are not falsely presenting themselves as the author's representative.

Turn now to his second syllogism, which responds to the unauthorized publisher's hypothetical defense of his actions. Here again, the major premise seems fairly plausible, so I will assume it is true that ownership of tangible property cannot generate positive rights against others. But, here again, the minor premise is questionable if understood too broadly. It is far from clear that embodying another's speech without permission unavoidably invokes any positive right against him or her. Kant's explanation for his minor premise asserts that a right to publish duplications of the physical copy the publisher rightfully owns would be

not merely a right of the publisher to defend himself against [the author] in regard to using his property as he pleases, but to compel [the author] to acknowledge as his own and be responsible for a certain affair that the publisher carries on in [the author's] name. ${ }^{69}$

Because the unauthorized publisher cannot truthfully avoid attributing the reproduced book to its true author, the unauthorized publication is (at least to some degree) carried on in the author's name and the author will be responsible for it.

\footnotetext{
${ }^{69}$ Kant, supra note $47,8: 84$, at 32-33; see also id. 8:83, at 32 (" [M] right to carry on some affair in another name is a positive right against a person, that is, to compel the author of this affair to perform something, namely to look after whatever he has had done through me or to which he has bound himself through me." (emphasis added)).
} 
It is no doubt reasonable for an author to object if others' actions result in his being held responsible for speech he has not chosen to deliver: think of the complaint that an academic author would have if a paper marked "DRAFT—Not for Circulation" were to be published on another's highly visible website without her consent, or that any author would have were her work quoted inaccurately. But once an author has chosen to deliver his speech to the general public and authorized its general distribution by someone, she has already accepted responsibility for the speech. Provided that the unauthorized copyist produces copies that are completely faithful to the contents of the original, those copies do not force the author to be responsible for or to acknowledge as his own any new affair. ${ }^{70}$ Kant may wish to distinguish the affair of delivering the speech contained in book $X$ from the affair of delivering the speech contained in book $X$ through

\footnotetext{
${ }^{70}$ One person who might deny this claim is Abraham Drassinower, whose theory of copyright takes many cues from Kant but is not presented as an exegesis of Kant's own theory. Unlike Kant, Drassinower does not stress the responsibility that unauthorized publication perhaps inappropriately forces on the author, but rather focuses on an objectionable sort of speech compulsion:
}

[T] he intuition that unauthorized publication of unpublished works is wrongful is equally applicable to the unauthorized publication of published works. What is wrong with each and both is that they amount to forcing another to speak. Unauthorized publication is compelled speech. The fact that an author has already spoken does not mean that we are thereby entitled to force him to speak again. A ventriloquist is not any less a ventriloquist because he compels me to say what I have already said. That his belly happens to speak through my mouth exactly what I have already spoken—or what I would have spoken-does not make me any less of a puppet. On the contrary, the injury is even greater where he uses my very own speech to treat me like one.

Abraham Drassinower, Copyright Infringement as Compelled Speech, in NEW FRONTIERS IN THE PHILOSOPHY OF INTELLECTUAL PROPERTY 203, 218-219 (Annabelle Lever ed., 2012). Kant's position clearly is that books embody a speech the author is delivering to the public and that she may prevent others from having her speak publicly if she has not consented to the speech. Kant, supra note 47, 8:86 n., at 35. But Drassinower appears to go further, characterizing each act of printing is a distinct act of speaking by the author. This characterization seems to be what underlies his ventriloquism analogy, and it has the metaphysically counterintuitive implication that each person who transcribes and publishes remarks delivered in public makes it the case that the speaker has just delivered the remarks again. For this reason, I do not find Drassinower's argument persuasive. Nor do I see any textual evidence that Kant endorses it. (As an aside, I would have thought it obviously much less of an injury to force someone to speak his own words than to force him to speak the words of somebody else.) 
publisher $P$. It might be that the public holds authors responsible for not just their speeches but also for the medium through which they deliver those speeches. As I agreed above while discussing Kant's first major premise, falsely representing oneself as another's authorized agent can wrong that person. But perhaps an unauthorized copyist could avoid committing such a wrong by means of a (truthful) disclaimer that the speech itself was the author's while the choice of copyist was not. Indeed, simply by presenting herself as the source of an "unauthorized edition," such a copyist could avoid this kind of wrongdoing and protect herself against any allegation that her copying an already-published book was asserting a positive right against its author.

So in reading Kant's two syllogisms, we must be careful not to attribute to him a rather weak pair of arguments for the excluding privilege to embody copyrightable speeches. But there is reason to believe he is not actually committed to the weak versions of these arguments. In introductory remarks that precede his discussion of unauthorized publication in the Rechtslebre, Kant expresses an intention to avoid concepts that are "entirely empirical and, even in terms of their possibility, have no proper place in a metaphysical doctrine of right, in which division must be made in accordance with a priori principles. ${ }^{71} \mathrm{He}$ also promises that his ensuing discussion will show that the concept of a book "can still be resolved into pure intellectual relations." ${ }^{72}$ Not surprisingly, then, that discussion leaves out several features of his early essay, which apparently did not share the more metaphysical ambitions of The Metaphysics of Morals, ${ }^{73}$ and these are the very

\footnotetext{
${ }^{71}$ KANT, supra note 4, 6:286, at 434 .

${ }^{72} I d$.

${ }^{73}$ Indeed, the aim of Kant's essay seems at least partly to be articulating a basis for bringing copyright claims to court under already applicable laws. See Kant, supra note 47, 8:87, at 35 ("If the idea of publication of a book as such,
} 
features that seem most empirically contingent. Take, for example, Kant's claim in the essay that unauthorized publication is not merely without the author's permission but also "against his will." ${ }^{74}$ Kant's argument on behalf of this claim depends on the assumption that having two publishersone authorized, the other not-would make the enterprise of printing the book economically impracticable. ${ }^{75}$ Not only is this assumption empirically contingent—and hence absent from the Rechtslebre-it is doubtful today. Compared to the eighteenth century, when printing an edition of a book required laboriously typesetting the whole manuscript by hand, ${ }^{76}$ the fixed costs of printing a book are now a small fraction of what they once were. And we in fact do occasionally see nonexclusive publishing agreements. So it seems that Kant's arguments in the On the Wrongfulness essay depend on certain contingent facts that are not necessarily present in every case of unauthorized embodiment of a copyrightable text.

Also notably absent in the Recbtslebre discussion is the earlier essay's second syllogism, with its questionable claims about the unauthorized publisher's assertion of a positive right. If, as I

on which this is based, were firmly grasped and (as I flatter myself it could be) elaborated with the requisite eloquence of Roman legal scholarship, complaints against unauthorized publishers could indeed be taken to court without it being necessary first to wait for a new law."); $c f$. KANT, supra note 4, 6:205-06, at 365 (noting that, unless great care is shown, it can be challenging "to distinguish what is metaphysics ... from what is empirical application of rights").

${ }^{74}$ Kant, supra note $47,8: 81$, at 31 .

${ }^{75} I d$. ("[T] he work of one of them would have to make that of the other unprofitable and injurious to each of them; thus it would not be possible for an author to make a contract with one publisher with the reservation that he might allow someone besides to publish his work."); see also id. 8:85, at 34 (grounding a publisher's "exclusive right to publish" a work in the fact that "others' engaging in his affair would make it practically impossible for him to carry it on.").

${ }^{76}$ See generally Rob Banham, The Industrialization of the Book 1800-1970, in A COMPANION TO THE HISTORY OF THE BOOK 273, 281-83 (Simon Eliot \& Jonathan Rose eds., 2007) (providing an overview of the nineteenth-century inventions that enabled mechanized typesetting). 
would suggest, this absence is explained by Kant's acknowledgement that not all unauthorized copying compels the author to take new responsibility for something, then we should interpret that syllogism as refuting the unauthorized publisher's purported right only to the extent that he or she is a publisher who would compel authors to take new responsibility for something.

Likewise, the manner in which the first syllogism survives in the Rechtslebre also gives us reason to question how broadly it was meant in the On the Wrongfulness essay. The nonempirical part of the syllogism that survives untouched in the Rechtslebre is the first premise's claim that it is wrongful to impersonate another's authorized agent (and the claims about what remedies are appropriate for such wrongdoing). In the Recbtslehre, the second premise survives as a matter of stipulation: at the outset, Kant simply says "One who, through a writing, discourses publicly in another's (the author's) name is a publisher. ${ }^{, 77}$ Perhaps copyists in Kant's time typically conformed to this definition, but in light of the cases we considered above, the definition seems dramatically under-inclusive today. It seems likely then, that Kant's conception of a publisher is different from our everyday conception. I would therefore read Kant's Rechtslebre argument as asserting that, to the extent that one falls within Kant's particular definition of a publisher-by passing oneself off as the author's authorized agent—publishing without the author's authority is wrongful. So interpreted, the argument is quite plausible but far less ambitious than a defense of the excluding privilege to embody copyrightable texts.

It is hard to be certain, though, that this interpretation accurately reflects Kant's own views. The best textual evidence that he meant to establish something closer to an excluding

${ }^{77}$ KANT, supra note 5, 6:289, at 437. 
privilege to embody appears at the end of the On the Wrongfulness essay, where he is defending unauthorized reproduction of visual works of art, such as drawings, engravings, and sculptures. While distinguishing such (permissible) reproduction from the (impermissible) reproduction of books, he writes:

But another's writing is the speecb of a person (opera), and one who publishes it can speak to the public only in the name of this other and can say no more of himself than that the author through him (Impensis Bibliopolae) delivers the following speech to the public. For it is a contradiction to deliver in one's own name a speech that, by one's own announcement and in keeping with the public's demand, is to be the speech of another. ${ }^{78}$

Kant is apparently suggesting here that it would be self-contradictory to disseminate another person's work in order to say something of one's own while honestly acknowledging that the speech is that other person's. This claim does not reappear in the Rechtslebre, but nothing suggests that Kant came to repudiate it. Here again, though, he seems to be basing his claim on a particular conception of publication — where publishers are necessarily understood as authors' appointed agents - rather than on duplication or copying as such. And whatever features are contained within this conception of publication, copying as such does not seem to entail the contradiction Kant is identifying. For while it would be contradictory for a copyist to say simultaneously that he was the author of certain speech and that another person wrote the very same speech first, copyists seem able to give voice to another's speech in their own name without asserting the two incompatible claims. So, for instance, the person who transcribes the words of a poem, with proper attribution to its author, and gives the copy to another person can reveal that he did not write the poem while

${ }^{78}$ Kant, supra note $47,8: 86$, at 34. 
also indicating that he is sharing the poem because it expresses his thoughts or feelings better than his own words could. Such speech is his in one sense but not his in another. ${ }^{79}$ Even in this passage, then, Kant need not be read as denying the possibility of unauthorized verbatim copying performed partly in the copyist's own name.

In any case, Kant's view contains two key lessons for our understanding of natural rights of intellectual property. First, his arguments, taken together, provide a firm footing for a right of attribution. As we have seen, Kant identifies the general wrongfulness of attributing to authors actions they did not perform. Not only is it wrong for an unauthorized publisher to pretend that an author has appointed her his agent; it is also wrong for the person who abridges, translates, or otherwise alters a text without authorization to mislead others into thinking that the author has made or approved those modifications. ${ }^{80}$ In other words, it is wrong to attribute actions to a person when he or she did not perform them. Although Kant did not discuss the problem of knock-off goods, which might not have been a big problem in Kant's day, his account clearly indicates that it would be wrong to use another's trademark on counterfeit goods in a way that suggests that they are the genuine article.

But Kant also suggests at one point that it would be wrong to attribute actions to oneself when they were actually performed by another. ${ }^{81}$ Kant does not elaborate, but it is not hard to build an argument for this second claim based on the rest of Kant's discussion. That whole

\footnotetext{
${ }^{79}$ Cf. id. 8:86 n., at 35 (explaining how the author of a book and someone who lawfully owns a copy of it "can both, with equal right, say of the same book, 'it is my book,' but in different senses").

${ }^{80} I d .8: 86-87$, at 35 .

${ }^{81}$ KANT, supra note 5, 6:289, at 437 (saying that a publisher cannot "pass himself off as the author").
} 
discussion emphasizes our interest in having control over what we do and in having a public reputation that accurately reflects what we have chosen to do. Someone who attempts to claim credit for another's work denies that person the reputation she deserves no less than the person who attributes actions to another that she did not perform. Either sort of action would violate an intellectual property owner's right of attribution.

Given his apparent commitment to a right of attribution, it is not surprising that Kant is often viewed as an early defender of what is called droit moral in copyright law, ${ }^{82}$ which encompasses, to varying degrees around the world, creators' rights to be identified as the creators of their works and to object to unauthorized alterations of their works that would injure their reputations. ${ }^{83}$ There is some controversy over the justifiability of the right of attribution and (especially) the right of creators to preserve the integrity of their work as they see it, ${ }^{84}$ but Kant's own proposal should not be controversial because it protects creators' reputational interests without placing a significant burden on others. ${ }^{85}$ It is no great loss for anyone if those who had no role in

${ }^{82}$ See, e.g., Charles R. Beitz, The Moral Rights of Creators of Artistic and Literary Works, 13 J. PoL. PHIL. 330, 341 (2005); Netanel, supra note 60, at 20-21.

${ }^{83}$ See, e.g., Berne Convention for the Protection of Literary and Artistic Works, art. 6bis, as amended on Sept. 28, 1979, S. Treaty Doc. No. 99-27, 1161 U.N.T.S. 3. In France, droit moral is quite broad and encompasses further rights, including the right to modify or withdraw works from the public and the right to decide whether and when to release works to the public. See generally Russell J. DaSilva, Droit Moral and the Amoral Copyright: A Comparison of Artists' Rights in France and the United States, 28 BULl. CopYRIGHT SOC'Y U.S.A. 1, 17-37 (1980) (discussing droit de divulgation, droit de retrait ou de repentir, droit à la paternité, droit au respect de l'oeuvre in French law). In the United States, federal law only recognizes the rights of attribution and integrity, and only for works of visual art. See 17 U.S.C. $\S \S 106 \mathrm{~A}, 113$ (d) (2006); see also Brian Angelo Lee, Making Sense of “Moral Rights" in Intellectual Property, 84 TEMP. L. REV. 71, 79-80 (2011) (identifying state statutes that protect visual artists' droit moral).

${ }^{84}$ See, e.g., Amy M. Adler, Against Moral Rights, 97 CALIF. L. Rev. 263, 265, 267 n.16 (2009); Stephen L. Carter, Owning What Doesn't Exist, 13 HaRV. J.L. \& PUB. POL'y 99, 100-01 (1990).

${ }^{85}$ Furthermore, it also protects audiences and society as a whole from being misled about the identity of whoever actually deserves responsibility for the actions. 
creating a work or who have not been appointed another's agent are prohibited from pretending otherwise. ${ }^{86}$ And the only Kant-endorsed right that could be called a right of integrity does nothing more than protect the artist's reputation; it does not stand in the way of subsequent alterations so long as they are not falsely attributed to the author. ${ }^{87}$ Some might claim that this version of droit moral affords insufficient protection. ${ }^{88}$ For my part, however, I think it affords just about the right level of protection when extended beyond authors of written works to creative people in general, although I will not defend that position here.

A second right follows from Kant's concern, in the On the Wrongfulness essay, that authors not be forced to acknowledge speech as their own and accept responsibility for it if they have not yet judged themselves ready to do so. This might be called a right of release. It would give creators of artistic expression some measure of control over the initial disclosure of their creations to the public. Although in some countries such a right exists and is viewed as part of droit moral, ${ }^{89}$ the right can also be found in legal systems that have not embraced droit moral. For example, well before the recognition of droit moral in American law, the doctrine known as common law

\footnotetext{
${ }^{86}$ Recall that a Kantian right of attribution only imposes duties on verbatim copyists; those who edit or otherwise alter a work are not supposed to suggest that the original author is also responsible for the changes. Setting aside Kant's views, however, I am inclined to think there is a rather gray area in which modifiers have some duty to indicate their indebtedness to the original creator of a work they are relying on, without attributing responsibility for the changes, if that can be done without much difficulty.

${ }^{87}$ Cf. Beitz, supra note 82, at 349 (“[A]s a general matter, the interests adversely affected by [alienable] Moral Rights seem to be few, assuming anyway that the system could be structured so as to minimize the potential for inhibiting future creativity.").

${ }^{88}$ See, e.g., John Henry Merryman, The Refrigerator of Bernard Buffett, 27 Hastings L.J. 1023, 1046-48 (1976) (advocating a relatively broad right of integrity, at least for works of visual art, that would limit owners' ability to make modifications without the artist's consent).

${ }^{89}$ See supra note 83.
} 
copyright prohibited the publication of an author's work before he or she consented to its public dissemination. ${ }^{90}$ Given that anyone who spreads sufficiently unaltered versions of artistic expression would be obligated to give credit to the material's actual creator, violating the right of release would necessitate the creator's assumption of responsibility for work even if she felt unprepared to assume that responsibility. In principle, there are other sorts of intellectual goods beside the copyrightable sort—what I am calling creative expression—unauthorized release of which would require attribution and thus reflect (whether well or poorly) on the resource's creator. ${ }^{91}$ If someone publicized another's non-copyrightable idea for a project while giving proper attribution, the latter's reputation might be affected, especially if others find that project laughable. And it would not be a tremendous consolation to such a person if the release of her work were to be accompanied by a disclaimer stating that she had not consented to the promulgation of the idea, because the disclaimer would still not change the fact that the idea was hers despite her lack of voluntary public commitment to it. Wherever this sort of dynamic is present, Kant's arguments seem to me to suggest that unauthorized release would be at least presumptively wrongful. ${ }^{92}$ Note,

${ }^{90}$ See, e.g., Bobbs-Merrill Co. v. Straus, 210 U.S. 339, 346 (1908) (citing Wheaton v. Peters, 33 U.S. (8 Pet.) 591, 659 (1834)). Of course, statutory protection for copyrights makes this common law copyright essentially superfluous today. Somewhat confusingly, "common law copyright" also occasionally refers to the (historically discredited) theory that the common law, prior to any copyright statute, recognized robust rights of copyright ownership. See generally Howard B. Abrams, The Historic Foundation of American Copyright Law: Exploding the Myth of Common Law Copyright, 29 WAYNE L. REV. 1119, 1129-33 (1983).

${ }^{91}$ Cf. Lynn Sharp Paine, Trade Secrets and the Justification of Intellectual Property: A Comment on Hettinger, 20 PHIL. \& PUB. AfF. 247, 251-52 (1991) (orienting trade secrecy law around a "right to control the initial disclosure of one's ideas," id. at 251).

92 I say "presumptively" because it is easy to imagine cases where the public has a very compelling interest in knowing about an idea that could justify concluding that the source of the idea has no right against its dissemination. Think of the political candidate who has expressed ideas only in private that have a strong bearing on how voters should cast their ballots. Further, there are many historical examples of artists who upon their deaths demand the 
however, as I have argued above, ${ }^{93}$ that faithfully duplicating already published ideas or artistic expression would not impose any new responsibility on the author and therefore would be permissible. It would also be completely permissible to develop another's idea or statements beyond the point at which attribution ceases to be required. But neither the right of release nor the right of attribution approaches the standard incidents of intellectual property ownership very closely, and so Kant's arguments, if I have interpreted them correctly, do not justify what we normally think of as intellectual property rights.

Kant's views about property and intellectual property offer a valuable supplement to the Lockean arguments we considered in the previous chapter. Locke's primary concern, as we saw, is with the individual's interest in having material benefits that are necessary for life or that make life more comfortable. Kant's discussions focus rather on the importance of having control over our own actions. I disagreed with Ripstein's interpretation of Kant's theory of physical property, according to which our ability to control what we do seemed to require that we have a very broad measure of control over anything that others do with our possessions. I claimed that Ripstein was overestimating our reasons to care about having control over uses of our property that do not interfere with our ends. But after turning to intellectual property, I agreed with Kant that our

destruction of their unpublished works. These cases raise difficult questions about proper respect for wishes of the dead that complicate the basic point I want to make here.

93 See supra notes 69-70 and accompanying text. 
interests in controlling what we do extends to having a reputation that faithfully matches what we have chosen to do. This interest, I claimed, justifies intellectual property rights of attribution and release.

In practice, these rights might closely resemble the Lockean natural intellectual property rights that I identified in the previous chapter. We have already seen how a right of attribution supports trademark's condemnation of knock-off goods, which would also be condemned under the theory of Lockean trademark that I advanced in the previous chapter. The difference, though, is that for Locke the interest that grounds the right against interfering uses of a trademarked logo is the trademark owner's interest in material gain, in gaining the necessities and conveniences of life. Having a good reputation can indeed promote our interests in material gain, but Kant seems to think that we also have non-instrumental reputational interests that derive from our interests in controlling what we do. Similarly, a right of release might, at least in certain circumstances, be justified as a protection against interference with labor. A few novelists famously experimented, while writing iconic works, with different plot elements before settling on the final version. ${ }^{94}$ If someone had acquired one of the early drafts of $A$ Farewell to Arms in which Hemingway allowed a certain character to survive ${ }^{95}$ and then published it as A Farewell to Arms before Hemingway could release the bleaker version that is familiar to us, he might fairly have complained that the unauthorized publication of a novel with a different ending kept him from creating $A$ Farewell to

\footnotetext{
${ }^{94}$ See, e.g., 3 John Forster, THE Life of CHARLES DiCKENS 335 (1874) (discussing a late change to the ending of Great Expectations).

${ }^{95}$ See ERnest HemingWay, A FARewell to Arms xviii, 305-06 (Séan Hemingway ed., Scribner 2012).
} 
Arms as he conceived of it. Perhaps such an author has reason to care about being free to create one version rather than another because the first will bring greater commercial success. But I see no reason to insist that all arguments on behalf of a right to release are based on interests in material gain. Someone might object to unauthorized release of a text he has written on the basis of other interests, such as an interest in quality control-that is, in making sure the final version of what he is producing is as good as possible, for its own sake. Even the author who planned to remain anonymous and thus had no reputational worries might have an interest in ensuring that her work was not released to the public before it was in adequate shape. And of course when certain texts are distributed without authorization, privacy is a significant concern.

So although there may be significant overlap between Kantian and Lockean natural rights of intellectual property ownership, we should not assume a perfect overlap. ${ }^{96}$ My claim in this dissertation is that we need a good understanding of all the interests that intellectual property rights affect in order to determine whether those rights are justified. Over the last two chapters, I have identified a few interests of creators that one might have thought were likely to furnish a natural rights-type justification for the standard incidents of intellectual property ownership, and argued that they in fact justify only a small subset of intellectual property laws. But I have not yet discussed another vitally important category of interest that is profoundly affected by intellectual property—namely, interests shared widely throughout society.

\footnotetext{
${ }^{96}$ Here is just one example of potential divergence: Sponsorship confusion, as I argued in the last chapter, seems to be one area of trademark law that Lockean principles fail to justify. Yet Kantian principles that denounce attributing to another actions she did not perform would seem to condemn at least some defendants whose trademark use conveys that the trademark owner has given her endorsement. Of course, the challenge is to develop legal doctrine that does not too readily find a likelihood of sponsorship confusion and that thus avoids placing too heavy a burden on those who make innocent use of another's marks.
} 


\title{
4. INSTITUTIONAL RIGHTS BASED ON SOCIETY'S INTERESTS
}

We need not consult Plato or Aristotle.

\author{
- Jeremy Bentham ${ }^{1}$
}

For my part, I almost always think Plato and Aristotle are worth consulting when they have something to say. And I think they have something to say here, even though our topic is intellectual property and they lived many centuries before anyone had given the subject much thought. One of their famous disagreements anticipated an important alternative to natural rights thinking about physical property ownership, and it will help us better understand the justifications of its incorporeal cousin. This ancient alternative would justify private property ownership not on the ground that anyone has a pre-legal claim to dominion over some particular object, but on the ground that the institution of private property functions well from society's perspective, at least compared to salient alternatives. In endorsing private property over communal ownership, Plato's preferred arrangement, Aristotle stressed its unworkability: "that which is common to the greatest number," he observed, "has the least care bestowed upon it." And it seems quite sensible for lawmakers to care about how well valuable objects are used. In fact, Aristotle's concern about socially harmful misuse of common property prefigured what would later be a theme of Bentham

${ }^{1} 1$ Jeremy Bentham, Theory of Legislation 4 (Étienne Dumont \& Charles Milner Atkinson eds. \& trans., 1914) (1802).

2 ARIstotle, Politics bk. 2, ch. 3, 1261b33-38, reprinted in 2 The COMPLete Works OF ARISTOTLE 1986, 2002 (Jonathan Barnes ed., B. Jowett trans., 1984). 
and his utilitarian successors. Bentham thought unrestricted hunting on unowned lands went against society's interests by jeopardizing the sustainability of the animal population. ${ }^{3}$ Henry Sidgwick raised a similar worry about common stocks of fish: fishermen are apt to overfish out of a narrow concern for their own gain if the law permits it. ${ }^{4}$ Modern economists have also studied these problems and identified private property as a possible solution, observing alongside Aristotle that owning a resource makes one less likely to waste its value. ${ }^{5}$ Private property can thus be defended as one socially useful strategy for avoiding "the tragedy of the commons."

This functionalist praise of private property's ability to discourage socially harmful behavior has an equally important corollary highlighting its ability to encourage socially beneficial behavior. There was no hope of human industry (or much else) in Thomas Hobbes's state of nature because industry's fruits could never be secure enough without law. ${ }^{7}$ David Hume thought that rules promoting stability in private possessions were "absolutely necessary to human society." 8 Bentham

${ }^{3}$ BENTHAM, supra note 1 , at 218 .

${ }^{4}$ Henry Sidgwick, The PrinciPles of Political ECONOMY bk. 3, ch. 2, § 5, at 410 (3d ed. 1901) (1883); see also John Stuart Mill, Principles of Political Economy bk. 5, ch. 11, § 12, at 966 (W.J. Ashley ed., 1909) (1848) (discussing how self-interested actors will rush to appropriate more unclaimed land than they can productively use if they fear that others will do likewise).

5 See Peder Andersen, “On Rent of Fishing Grounds”: A Translation of Jens Warming's 1911 Article, with an Introduction, 15 Hist. POL. ECON. 391, 392-93 (1983) (translating Jens Warming, Om Grundrente af Fiskegrunde, 49 NAtionaløKONOMisk TidssKRIFT 49 (1911)); H. Scott Gordon, The Economic Theory of a Common-Property Resource: The Fishery, 62 J. POL. ECON. 124, 135 (1954).

${ }^{6}$ Garrett Hardin, The Tragedy of the Commons, 162 SCI. 1243, 1244-45 (1968).

${ }^{7}$ Thomas HobBes, Leviathan ch. 13, [62], at 84 (A. R. Waller ed., Cambridge Univ. Press 1904) (1651).

${ }^{8}$ David Hume, A Treatise of Human Nature bk. 3, pt. 2, § 3, at 501 (L.A. Selby-Bigge \& P.H. Nidditch eds., Oxford Univ. Press 2d ed. 1978) (1739-1740). 
of course knew Hobbes's and Hume's work and followed them on this point: "It is the law alone which makes it possible for me to forget the insecurity of my natural condition, and emboldens me, with reasonable hope of a harvest as yet far distant, to enclose a plot of land and give myself up to the toil of cultivation."' Because property could not exist without law, according to Bentham, neither could security, abundance, or any assurance of subsistence. ${ }^{10}$

Several functionalist considerations thus speak in favor of private property institutions. The aim of this chapter is not to dwell on them, but to consider how analogous considerations might be used to support intellectual property. More abstractly, my aim here is to examine the proper place of functionalism in the design of intellectual property institutions. I will propose that designers of those institutions should be more like Aristotle than Bentham: keenly aware of the utility of their designs, but not utilitarians. Of course, Bentham's disregard for Plato and Aristotle was actually rooted not in doubts about their ability to make perceptive observations about the functioning of social institutions, but in a rejection of their criteria for evaluating those institutions. The touchstone of Benthamite happiness is the everyday concept of pleasure, not some virtue-dependent concept of eudaimonia. ${ }^{11}$ (And yet Bentham flirted with the idea of calling himself a "eudaimonologian" rather than a "utilitarian,"12 narrowly avoiding a branding misstep that might have dramatically altered the course of modern moral philosophy.) But obviously, Bentham

\footnotetext{
${ }^{9}$ BENTHAM, supra note 1 , at 146.

${ }^{10}$ Id. at $142,145$.

${ }^{11}$ See id. at 3-4.

${ }^{12}$ John Bowring, History of the Greatest-Happiness Principle, in 1 Jeremy Bentham, Deontology 286, 320 (John Bowring ed., 1834).
} 
and his fellow utilitarians do not reserve harsh judgment for pre-Epicurean Greeks; they lavish it on anyone who resists utilitarianism for whatever reason. Although I will be challenging utilitarianism here, I will not be advocating any specific nonutilitarian theory. Rather, I will advocate examining how well social institutions function without assuming that nonutilitarian normative considerations are irrelevant.

Before proceeding, let us characterize institutional utilitarianism as the view that designers of legal institutions should be guided only by the effects of their decisions on total (or average) levels of individual well-being across some population. ${ }^{13}$ Although there are a few different ways to characterize well-being, as we will see, for now it can be understood roughly as a measure of how well an individual's life is going for her. In the next few sections, I will argue that the prospect of designing intellectual property institutions undercuts institutional utilitarianism's appeal in a special way by exposing how unlikely utilitarianism is to deliver determinate judgments about how social institutions should be designed. Then, I will use a few examples from intellectual property law to sketch a nonutilitarian approach to institutional design — an approach that is highly sensitive to an institution's overall effects but open to other normative considerations as well. And finally, I will explain how institutions designed to promote society's interests can nonetheless give rise to individual rights.

\footnotetext{
${ }^{13}$ For classic and contemporary endorsements of institutional utilitarianism, see, respectively, JEREMY BENTHAM, AN INTROdUCtion to the PRINCIPLES OF MORALS AND LEGISLATION ch. 1, § 1, at 1 n.1 (Clarendon Press 1907) (1823); and LOUIS KAPLOW \& STEVEN SHAVELL, FAIRNESS VERSUS WELFARE xvii (2002).
} 


\subsection{INTELLECTUAL PROPERTY FunCTIONALISM AND UTILITARIANISM}

It is easy to identify a valuable function that intellectual property institutions could perform. Society has an extremely strong interest in the existence of the sorts of things that intellectual property owners own-expressive works, useful information, and so forth. Not only does any given individual have an interest in having access to such things for her own use, but she also has an interest in such things' existence apart from the possibility that she herself will ever use them, since others might use them in ways that benefit her. Unfortunately, effort is typically necessary before such things are available and suitable for use, and yet the person who expends such effort will find it difficult to exclude anybody else from the thing she works to produce unless she wants to exclude everybody from it. Information and artistic expression can easily spread throughout groups of people regardless of the laborer's wishes, especially given the right technology. The laborer may therefore fail to recoup her fixed costs: once the information or expression she produces, or an object embodying it, is sold to a few people, many others may be able to acquire the fruits of her labor from one of the early purchasers without further compensating her for her investment. Free-riders can even compete with her at a great advantage. Consider the person who reverse-engineers Thomas Edison's light bulb design without having to spend countless hours testing different filament materials, or who sells flawless copies of symphony recordings without having to hire an orchestra to record them. If the technology needed for copying exists and the law does not intervene, there will be less investment in producing the sorts of things that can be the subject of intellectual property ownership. For although some individuals may be willing to do the work for little or no pay, many will not. And so copyright and patent law 
may seem justified for their ability "[t]o promote the Progress of Science and useful Arts," as the U.S. Constitution puts it. ${ }^{14}$

These observations are plainly analogous to part of the functionalist case for regular property that we saw in this chapter's introduction-namely, the part stressing property law's ability to protect investment and thereby increase prosperity overall. And indeed, that is exactly how Bentham justified patents. He approved of patent laws for the very same reason he approved of property laws: both encourage socially beneficial behavior through the promise of security. ${ }^{15}$ This is the incentive function of intellectual property.

Bentham went on, however, to claim that patent law "costs nothing," 16 and this claim is dubious. Bentham's analysis of intellectual property's effects was incomplete. Recall that, for

\footnotetext{
${ }^{14}$ U.S. CONST. art. I, § 8, cl. 8. The functionalist case for trademark is slightly different. Compared to encouraging knowledge, art, and invention, encouraging the production and development of brand names, corporate logos, and advertising slogans does not seem so clearly in society's interest. But even these can be called intellectual goods because they possess (at least) second-order value as means of facilitating communication by those who sell products with firstorder value to prospective consumers. It is easier for the car purchaser who knows what she wants to obtain it by specifying the make and model rather than by listing its unique characteristics. Trademarks make it easier for consumers to search for goods with consistent features. William M. Landes \& Richard A. Posner, Trademark Law: An Economic Perspective, 30 J.L. \& ECON. 265, 268-70 (1987).

${ }^{15}$ Bentham wrote:

With respect to a great number of inventions in the arts, an exclusive privilege is absolutely necessary, in order that what is sown may be reaped. In new inventions, protection against imitators is not less necessary than in established manufactures protection against thieves. He who has no hope that he shall reap, will not take the trouble to sow. But that which one man has invented, all the world can imitate. Without the assistance of the laws, the inventor would almost always be driven out of the market by his rival, who finding himself, without any expense, in possession of a discovery which has cost the inventor much time and expense, would be able to deprive him of all his deserved advantages, by selling at a lower price.
}

Jeremy Bentham, A Manual of Political Economy, in 3 The Works of Jeremy Bentham 30, 71 (John Bowring ed. 1839); see also MiLl, supra note 4, bk. 5, ch. 10, § 4, at 932-33.

${ }^{16}$ BENTHAM, supra note 15 , at 71 . 
physical property, private ownership not only encourages productive use but also discourages wasteful misuse. With information and creative expression, however, there is no tragedy of the commons as there is with common pools of fish, ${ }^{17}$ for using such goods typically does not deplete the supply available to others. If intellectual property performs its incentive function, it actually increases the total supply of usable things. Yet intellectual property ownership performs its incentive function only by giving owners power to regulate others' access and thus restricting society's use of the intellectual property. This feature of intellectual property affects social welfare in a different way, and not for the better. Instead of preventing overfishing, it is possible that intellectual property causes the functional equivalent of underfishing. ${ }^{18}$

The standard incidents of intellectual property ownership that enable an owner to restrict others' access to her intellectual property permit her to charge abnormally high prices for that access. More specifically, intellectual property’s exclusive rights enable monopoly pricing by curtailing the production of substitute goods. The following (stylized) graph illustrates the social harm of such pricing:

${ }^{17}$ As Sidgwick and many others have observed. HeNRY SIDGWICK, THE ELEMENTS OF Politics ch. 10, § 5, at 157 (2d ed. 1897).

${ }^{18}$ See, e.g., Robert P. Merges \& Richard R. Nelson, On the Complex Economics of Patent Scope, 90 CoLuM. L. REV. 839, 873 (1990). 


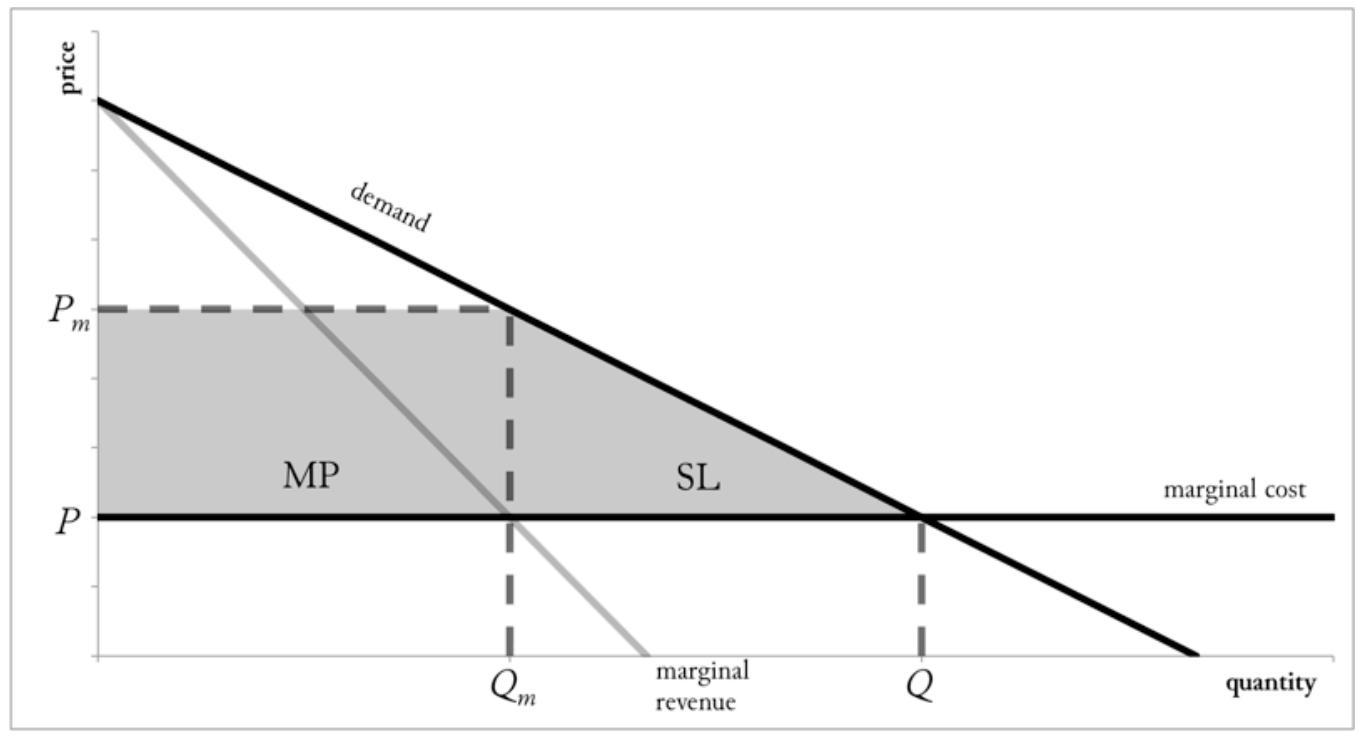

Figure 1

In an ideally competitive market, the price of goods equals the marginal cost of production-the price of producing the next individual one. And when a good's price equals its marginal cost $(P)$, social welfare is maximized and the optimal quantity of the good $(Q)$ is produced and enjoyed; whoever derives a benefit from the good that equals or exceeds its cost obtains it. But under monopoly pricing, the lack of normal competition allows the monopolist to charge a higher price $\left(P_{m}\right)$, greater than the good's marginal cost, which maximizes the monopolist's profits (shaded rectangle MP). ${ }^{19}$ In so doing, they not only gain at consumers' expense (though this is not necessarily bad from a social welfare perspective), they also end up producing a lower-than-sociallyoptimal quantity of goods $\left(Q_{m}\right)$. Now someone who values a particular good more than it costs to

\footnotetext{
${ }^{19}$ For ease of presentation, I assume that the marginal cost and average total cost are equal whatever quantity of goods is supplied.
} 
produce but less than the monopolist charges will not obtain it, resulting in a social loss (shaded triangle SL). ${ }^{20}$

The cost of intellectual property is actually even higher. For the problem is not simply that a mass of individual consumers who value a good more than $P$ but less than $P_{m}$ will derive less personal satisfaction than is warranted given the good's cost. Rather, since tomorrow's breakthroughs builds on today's, there is an additional risk that intellectual property laws will prohibitively increase the costs of those who would have used such goods to produce further innovations that would have increased social welfare. If after the commercialization and patenting of the internal combustion engine, every one sold by the patentee was priced above marginal cost, some tinkerers and aspiring inventors may not have sought access to the engines at the higher price, and society may have lost out on some new machines that would have been invented (or invented sooner) if they had had that access. Moreover, intellectual property ownership directly discourages follow-on innovation through the standard incident I have called the excluding privilege to develop. Copyright law expressly prohibits preparing new works, such as translations and other adaptions, that derive from a copyrighted work; under this rule, one could not develop a copyrighted novel into a screenplay, for instance, without permission from the copyright holder. ${ }^{21}$ Patent law prohibits unauthorized development of patented intellectual goods less directly, but in certain circumstances it allows patentees to obtain patents blocking not-yet-commercialized

\footnotetext{
${ }^{20} \mathrm{I}$ am also assuming away the possibility of price discrimination.

${ }^{21} 17$ U.S.C. $\S \S 101,106$ (2006).
} 
improvements of their inventions. ${ }^{22}$ Although it is possible copyright owners or patentees might license subsequent developments or improvements that rely on their earlier work, it is also possible they will not do so. They might disapprove of the changes or seek to suppress the competition. Whatever their purposes, there is no guarantee that they will be guided by society's interests rather than their own.

Of course these concerns do not amount to a conclusive case against intellectual property, at least if it truly performs its incentive function. Although monopoly pricing results in suboptimal production of goods, it could be worse yet to have no intellectual property whatever. For then the valuable intellectual resource might never have been created or developed, and something is better than nothing. Surely Bentham himself would have made this argument had he been pressed to defend his assertion that the exclusivity created by patent law is costless. He knew very well that monopolies cause problems, but he still defended monopoly-like legal entitlements, including patents, out of the belief that they produce greater good overall. ${ }^{23}$ Sidgwick explicitly mentioned concerns that intellectual property might restrict others' ability to improve or develop the protected intellectual good and suggested that the laws be designed carefully. ${ }^{24}$ According to functionalism, then, a principal task for policymakers is to design intellectual property institutions so that their benefits are many and their costs few. At a minimum, intellectual property protection

\footnotetext{
${ }^{22}$ See generally Mark A. Lemley, The Economics of Improvement in Intellectual Property Law, 75 TEX. L. REV. 989, 1000-07 (1996).

${ }^{23}$ See Jeremy Bentham, DefEnCe Of UsURY, in 3 The Works of Jeremy Bentham, supra note 15, at 1, 28-

${ }^{24}$ SIDGWICK, supra note 17 , ch. $19, \S 3$, at 342 .
} 29. 
seems unwise when little or no special incentive is necessary to encourage the development and commercialization of the good. Some scholars question whether copyright is necessary for academic authors, who may have adequate motivation to publish without it. ${ }^{25}$ But even if we limit intellectual property to the cases where some special incentive is needed, many questions remain, such as how broad intellectual property coverage should be and how long it should last. ${ }^{26}$

There is now a large literature on precisely such questions, but no firm consensus. Or, if there is a consensus, it is a disappointing one. Many economics-and-empirics scholars have come to believe, with Ronald Cass and Keith Hylton, that "little empirical evidence exists to shed light on the issues central to the design of intellectual property rights. ${ }^{27}$ Robert Merges goes even further, saying that because he has "become convinced that with our current tools we will never identify the 'optimal number' of patented, copyrighted, and trademarked works," he finds it important to seek non-functionalist guidance. ${ }^{28}$ Although we differ over what conclusions should be drawn from non-functionalist considerations, I agree with Merges that we ought to consider them. Indeed, I would go so far as to claim that sometimes policy ought to be determined

${ }^{25}$ E.g., Steven Shavell, Should Copyright of Academic Works Be Abolished?, 2 J. Legal AnALYsis 301, 304 (2010) (arguing that it is likely socially undesirable to grant copyrights to academic authors-who are motivated by a desire for readership —at least to the extent that the universities and grantors who fund them would be willing to defray the costs of publishing).

${ }^{26}$ Alternatively, a policymaker could attempt to secure the benefits using some sort of incentive that would avoid monopoly pricing altogether-for instance, a direct subsidy or prize system-though these systems have their own costs.

${ }^{27}$ Ronald A. CASS \& Keith N. Hylton, LaWs of Creation: Property RightS IN THE WORLD OF IDEAS 45 (2013); accord William Fisher, Theories of Intellectual Property, in NEW EsSAYS IN THE LEGAL AND POLITICAL THEORY OF ProperTy 168, 181 (Stephen R. Munzer ed., 2001).

${ }^{28}$ Robert P. MERges, Justifying Intellectual Property 3 (2011). 
exclusively by non-functionalist principles. For instance, one can speculate that a lot of wealth would be generated if intellectual property creators had full freedom to alienate the right of attribution that in the last chapter I claimed they ought to have. Even if it turned out that the average or total well-being within a society would be increased by a law that permitted individuals to buy the right to claim falsely that they created work they did not in fact create, that would not establish, in my view, that we ought to adopt such a law. But it is not clear that all intellectual property scholars agree, for it is routinely said that the most popular approach to intellectual property is utilitarianism. ${ }^{29}$ And as I understand utilitarianism, it rules out any normative criteria other than overall levels of well-being, including concern that some action promoting overall wellbeing would do so by means of a lie. Now perhaps those who think of themselves as intellectual property utilitarians really just endorse functionalist thinking about the subject, and are no more utilitarian than Aristotle. They might agree with me that a law facilitating dishonesty would not be justified just because it improved overall well-being a little bit. Some legal scholars, however, clearly do endorse institutional utilitarianism in the sense I have described, and maintain that it is categorically inappropriate to base social institutions on anything other than the expected effects on overall well-being.

The most prominent examples are Louis Kaplow and Steven Shavell. They start with an uncontroversial premise-namely that effect on individuals' well-being is a very important factor for evaluating the design and functioning of social institutions—and proceed to argue that

\footnotetext{
${ }^{29}$ E.g., Fisher, supra note 27, at 169; see also, e.g., Jeanne C. Fromer, Expressive Incentives in Intellectual Property, 98 VA. L. REV. 1745, 1750-51 (2012) ("The Supreme Court, Congress, and many legal scholars consider utilitarianism the dominant purpose of American copyright and patent law." (footnotes omitted)).
} 
institutional design should not look to any other normative factors because in so doing it compromises the institution's ability to achieve positive effects on individuals' well-being. ${ }^{30}$ Of course, this would be no argument at all if it only pointed out that pursuing other aims might be expected to result in lower amounts of overall well-being than would the single-minded pursuit of individuals' well-being. Anyone who understands what institutional utilitarianism amounts to and rejects it foresees this possibility and is willing to tolerate it. Kaplow and Shavell, however, make a seemingly more ambitious claim. Not only, they argue, might resorting to nonwelfarist considerations decrease the well-being of certain individuals in the population we care about or even decrease the total amount or average level of well-being in the population; they claim that using nonwelfarist criteria may actually decrease the well-being of every single person within the population. $^{31}$

This conclusion may startle even someone who is inclined to reject institutional utilitarianism. It is one thing not to care about individuals' well-being exclusively, but something else to be willing to overlook it entirely. But Kaplow and Shavell's claim is less startling that it first appears. In fact, it proves true by definition. ${ }^{32}$ Despite some language that might naturally be read to suggest the contrary, ${ }^{33}$ they are not claiming that there is a significant probability that

\footnotetext{
${ }^{30}$ See, e.g., KAPLOW \& SHAVELL, supra note 13, at 52.

${ }^{31}$ Id. at $52-54$ \& n.75.

${ }^{32}$ Even Kaplow and Shavell acknowledge that their claim is "virtually a tautology." Id. at 58. I do not think they need the "virtually."

${ }^{33}$ See, e.g., id. at 7 ("[P] ursuing notions of fairness is necessarily at the expense of individuals' well-being ...."); $i d$. at 53 ("[C] onsistently adhering to any notion of fairness will sometimes entail favoring regimes under which every person is made worse off.").
} 
nonutilitarianism will actually decrease everyone's well-being. All they are saying is that someone who wants policy decisions influenced by some nonwelfarist consideration-that is, who wants policy not to be determined solely on the basis of expected effects on individuals' well-being ${ }^{34}$ — can be made to confront conceivable cases in which the policy they think ought to be adopted makes every individual worse off. ${ }^{35}$ And adhering to nonutilitarianism in those possible cases would violate a widely accepted version of the Pareto principle that requires adopting any policy that makes every person better off. And so if one accepts this Pareto principle, one must reject nonutilitarianism, lest one be caught defending inconsistent principles. ${ }^{36}$

Kaplow and Shavell seem to believe that anyone who is presented with this incompatibility between nonutilitarianism and this Pareto principle will reject the former, but in my view rejecting the Pareto principle has greater appeal. ${ }^{37}$ In its place, the nonutilitarian can affirm a qualified version of the Pareto principle that avoids the incompatibility: if it is only prima facie true, or true ceteris paribus, that any policy making everyone better off should be adopted, then there is no conflict for the nonutilitarian who refuses to make everyone better off when doing so would violate her nonutilitarian commitments. And presumably many real-life nonutilitarians actually hold some

\footnotetext{
${ }^{34} I d$. at 39.

${ }^{35}$ Id. at 53 n. 75 .

${ }^{36} I d$. at 56.

${ }^{37}$ In his earlier work on this topic, by contrast, Amartya Sen took seriously the possibility of rejecting the weak Pareto principle in order to preserve a form of liberalism. See Amartya Sen, The Impossibility of a Paretian Liberal, $78 \mathrm{~J}$. POL. ECON. 152, 157 (1970); see also KAPLOW \& SHAVELL, supra note 13, at 54 n.75.
} 
such conception of the Pareto principle, fully in keeping with their nonutilitarianism. ${ }^{38}$ By way of example, nonutilitarians who think it is always impermissible to lie may also think that, other things equal, one ought to make others better off. But if they are presented with a case in which lying would make everyone better off-including, let us assume, the liar herself, who derives enormous happiness from the thought of taking one for the team-these nonutilitarians would surely insist that lying in this case is impermissible. Ultimately, all Kaplow and Shavell show is that in deciding whether to be a utilitarian, one must choose between following an absolutist Pareto principle and following some nonwelfarist principle.

But just as one cannot responsibly make such a choice without specifying which nonwelfarist principle is under consideration, one cannot responsibly make the choice without giving more content to the notion of well-being that the absolutist Pareto principle threatens to employ. Although Kaplow and Shavell take themselves to be offering an argument whose success does not depend on the appeal of their particular conception of well-being, ${ }^{39}$ the argument still depends on some conception of well-being having sufficient appeal to the nonutilitarian, who will not find Kaplow and Shavell's arguments troubling unless, when she contemplates the possibility of Pareto violations, she ceases to want to opt for her preferred nonwelfarist criterion over the welfarist criterion. ${ }^{40}$

\footnotetext{
${ }^{38}$ Similarly, nonutilitarians might want to reject an unqualified "strong" Pareto principle requiring any policy that makes at least one person better off and no one worse off.

${ }^{39}$ See, e.g., KAPLOW \& SHAVELL, supra note 13, at $52 \mathrm{n} .73$ (claiming that their "argument is applicable even if one adopts a conception of well-being different from the welfare economic conception" that they endorse).

${ }^{40}$ See Richard H. Fallon, Jr., Should We All Be Welfare Economists?, 101 MicH. L. REV. 979, 991 (2003).
} 
Kaplow and Shavell's main argument is thus unlikely to convert us diehard nonbelievers to institutional utilitarianism, but I wonder about its appeal even to those who already find themselves on the road to conversion. Someone attracted to an absolutist Pareto principle should still not assent to utilitarianism on the basis of what Kaplow and Shavell say because their claims run together two conceptions of nonutilitarianism: one which would base policy decisions on nonutilitarian criteria regardless of the effects on individuals' well-being ${ }^{41}$ and one which would base a policy decision on a nonutilitarian criterion only in certain situations. ${ }^{42}$ Their claim that nonutilitarianism countenances conceivable violations of an absolutist Pareto principle is only true for the first conception of nonutilitarianism, but they seem to believe that it holds for the second as well. ${ }^{43}$ Yet the two conceptions of nonutilitarianism come apart. Someone might be a nonutilitarian and yet only act on nonwelfarist considerations when the effects on well-being fall within acceptable limits.

Thus some conceivable versions of so-called threshold deontology seem to avoid Kaplow and Shavell's concerns. For instance, someone might support basing policy on nonwelfarist criteria but only when doing so would not make everyone worse off. Kaplow and Shavell's Pareto-based

${ }^{41}$ E.g., KAPLOW \& SHAVELL, supra note 13, at 6 (focusing on "principles employed to assess the desirability of legal rules without regard to the effects of the rules on individuals' well-being").

${ }^{42}$ E.g., id. at 52 (focusing on methods of assessment that do not "depend exclusively on the effects of legal rules on individuals' well-being").

${ }^{43}$ See id. at 56 (" $[\mathrm{I}] \mathrm{f}$ one adheres to the view that it cannot be normatively good to make everyone worse off, then logical consistency requires that one can give no weight in normative analysis to notions of fairness because doing so entails the contrary proposition ....”). 
argument for institutional utilitarianism does not touch this nonutilitarian proposal. ${ }^{44}$ They would say, of course, this theory seems awfully ad hoc and probably not defensible in the end. ${ }^{45}$ And they may be right about this, but perhaps other species of nonutilitarianism fare better. Consider the view that policymakers should rely on some criterion other than well-being just in case the policy under consideration would not decrease overall well-being relative to its leading competitors. ${ }^{46}$ This species of nonutilitarianism-which gives lexical priority to the effects on overall well-beingseems less contrived than the previous one, although perhaps it cannot be cogently defended, either. But if it could be defended, should we take it seriously as a possible alternative to nonutilitarianism? It might seem virtually indistinguishable from institutional utilitarianism, for one suspects that any two intellectual property proposals are unlikely to have exactly the same effects on overall well-being. How often will two policies be such that neither promotes overall well-being better than the other?

In the next section, I argue that by contemplating the design of intellectual property institutions, we will see that this sort of occurrence may be more common than one initially thinks. This fact is worth appreciating, not simply because it might furnish another reason for

\footnotetext{
${ }^{44}$ This form of nonutilitarianism would be compatible with the Pareto principle because (to put the point in somewhat technical language) it specifies a "social welfare function" that is not continuous in any good. $C f$. Louis Kaplow \& Steven Shavell, Any Non-Welfarist Method of Policy Assessment Violates the Pareto Principle, 109 J. PoL. ECON. 281, 284 (2001) (assuming that the nonutilitarian's social welfare function exhibits continuity for at least one good-to wit, any good the possession of some amount more of which would increase the possessor's well-being).

${ }^{45}$ See KAPLOW \& SHAVELL, supra note 13, at 55 n.76.

${ }^{46}$ Howard Chang stresses this possibility in his critique of Kaplow and Shavell's argument. See Howard F. Chang, A Liberal Theory of Social Welfare: Fairness, Utility, and the Pareto Principle, 110 YALE L.J. 173, 225 (2000). In recent work, Jeanne Fromer comes close to endorsing this approach to intellectual property law. See Fromer, supra note 29, at 1748.
} 
resisting Kaplow and Shavell's specific argument for institutional utilitarianism. Rather, it is important to establish that real-world decisions might not have determinate effects on overall wellbeing one way or the other because doing so undermines what I suspect is one significant source of institutional utilitarianism's appeal. By exclusively focusing on overall levels of individuals' wellbeing, institutional utilitarianism seems to promise a coherent and comprehensive account detailing exactly which social policies ought to be selected using a single criterion with some intuitive normative importance. Utilitarians often take their theory to furnish more determinate guidance than alternatives. ${ }^{47}$ If this promise of determinacy is indeed part of their theory's appeal, ${ }^{48}$ institutional utilitarians should feel anxious about the prospect of designing intellectual property laws. The institutional designer who attempts to get along without any criteria besides well-being cannot get as far as utilitarians seem generally to expect, and the difficulty is not merely that we do not yet have all the empirical evidence we need.

\subsection{UTILITARIANISM'S LIMITED UTILITY}

Institutional utilitarianism has long had to face the challenge of making interpersonal trade-offs when policies benefit some individuals but harm others, for the theory needs some way

47 See, e.g., KAPLOW \& SHAVELL, supra note 13, at 470 (criticizing nonutilitarians for not "stat[ing] the principles they are defending with some degree of precision and in a manner that is reasonably complete”); HENRY SIDGWICK, THE METHOD OF ETHICs bk. 4, ch. 3, § 1, at 425 (7th ed. 1907) (claiming that utilitarianism has an advantage over the "Morality of Common Sense" because it can deliver more precise guidance).

${ }^{48}$ I agree with Amartya Sen and Bernard Williams that "completeness is often seen as a merit, and it is a characteristic that utilitarianism pretends to enjoy." Amartya Sen \& Bernard Williams, Introduction to UTILITARIANISM AND BEYOND 1, 17 (Amartya Sen \& Bernard Williams eds., 1982). This chapter attempts to substantiate their charge that utilitarianism's completeness “pretension is not altogether well grounded.” Id. 
of assessing the overall effects of an policy on a multitude of individuals affected in different ways. My concern in this section is different. I want to set aside doubts about aggregation and interpersonal comparison and simply take for granted that if the utilitarian knew whether each individual would be better off under policy $A$ or under policy $B$, she could then determine which policy would make the population better off overall. Even taking that for granted, though, utilitarianism faces further difficulty because one cannot simply assume that, for any two intellectual property institutional alternatives, one will be better from the standpoint of a representative individual's well-being than the other. To be sure, some imaginable pairs of possible intellectual property laws will be such that one alternative is easily judged better, and the other worse, from an individual's standpoint. But the utilitarian should not assume that every pair of possible intellectual property laws can be ranked in this way. And if that is so, reflecting on intellectual property utilitarianism reveals that utilitarianism's apparent comprehensiveness-its seemingly unending ability to deliver verdicts about what to do solely on the basis of well-beingis illusory. So even if utilitarians can identify a normatively appealing conception of individual wellbeing, and even if they figure out a way to use it to draw interpersonal comparisons, they still cannot truthfully claim that any two policies can be ranked in terms of their effect on it. Indeed, the challenge for those who think policy should be based exclusively on welfarist criteria is not merely that we do not yet have conclusive information about which intellectual property institutions promote the most well-being. Rather, it is that conclusive information of this sort might be unattainable in principle because whether one option makes a person better off than another option may be indeterminate. 
As we saw in the last section, the effects of intellectual property law on any individual's well-being are complex. But as a general matter an individual is often better off when some invention or copyrightable expressive work exists than when it does not, because he (and others) can only put things that exist to good use. We saw that inventions or expressive works that exist must furthermore be accessible to be of value to anyone, but I will assume that whatever laws we might enact would make the goods that result accessible to the same non-negligible degree. Even if the goods that result from two alternative intellectual property proposals are equally accessible, I argue there is a very realistic possibility that neither proposal will be better than the other on account of the value of the particular objects resulting from each. To keep things simple, in defending this claim I will focus only on copyright proposals and the expressive works whose production they encourage.

Imagine, then, we have two copyright laws before us that could be enacted to provide incentives for creativity. Enacting the first option would result in a particular bundle $(A)$ of expressive works—-perhaps a novel, a film, and two different musical compositions:

$$
A=\{a, b, c, d\}
$$

Enacting the second option would result in a different bundle $(B)$ — the same novel, the same film, and two different sculptures:

$$
B=\{a, b, e, f\}
$$

In most cases, we will be unable to determine which option makes an individual better off without determining whether the existence of the $A$-bundle or the existence of the $B$-bundle would make her better off. Again, if a work does not exist, no one has an opportunity to benefit from it. 
But can we tell which bundle makes a typical individual better off? That depends on how exactly the existence of expressive works affects a person's well-being, and that in turn depends on what exactly well-being amounts to. This issue, of course, has long been a matter of controversy between utilitarians and between them and their opponents. As I noted at the beginning of this chapter, Bentham thought well-being consisted in having pleasurable experiences of varying intensity; he also refused to draw any distinction-of-kind between pleasure and benefit, advantage, good, happiness, or even the absence of pain. ${ }^{49}$ This welfare monism led him to suppose that one could in theory calculate the utility an individual would derive from a particular action by quantifying and adding up the amounts of pleasure he or she would eventually get as a result. ${ }^{50}$ On this view of well-being, it is simply detectable — either by the person feeling it or, as we might suppose today, by some sort of skilled neuroscientist. If this is what well-being is like, then perhaps utilitarians are right to believe we can calculate and compare any two copyright policies' effects on one individual's well-being. Suppose we can measure the amounts of pleasure-based utility $(\mathrm{u})$ that the individual gets from using or consuming the goods in the $A$ - and $B$-bundles:

${ }^{49}$ See Bentham, supra note 13 , ch. $1, \S 3$, at 2 .

${ }^{50}$ Id. ch. 4, § 5, at 30-31; see also RicHARD B. BRANDT, A THEORY OF THE GOOD AND THE RigHT 255-57 (1979). 
$A$-Bundle Utilities

$$
\begin{aligned}
& \mathrm{u}(a)=2 \\
& \mathrm{u}(b)=1 \\
& \mathrm{u}(c)=5 \\
& \mathrm{u}(d)=1
\end{aligned}
$$

$B$-Bundle Utilities

$$
\begin{aligned}
& \mathrm{u}(a)=2 \\
& \mathrm{u}(b)=1 \\
& \mathrm{u}(e)=2 \\
& \mathrm{u}(f)=2
\end{aligned}
$$

With such information, the comparison is easy: since $\mathrm{u}(A)=9$ and $\mathrm{u}(B)=7$, the individual will derive more utility if the option producing the $A$-bundle is selected. If well-being can be detected and added up in this way, my doubts about measuring a policy's effects on one individual's wellbeing may be easily overcome.

But it is awfully hard to believe that this is what well-being is like. Even granting the doubtful claim that the quality of our felt experiences is the exclusive measure of what makes our lives go well, there is another problem with the Benthamite conception of well-being more pertinent to the issue we are considering. When one reflects upon the variety of pleasures to be found in this world, it is hard to conclude that a single feeling is common to all of them but lacking whenever we feel pain. Now perhaps this fact of phenomenology should convince us to take a different, arguably more Aristotelian approach to pleasure-viewing pleasure not as a distinctive feeling that we sometimes have, but rather as a sort of positive evaluative response to some of the feelings that we have. ${ }^{51}$ But my aim is not to defend some controversial position on the nature of pleasure, a complex question to be sure. Rather, I mean only to suggest that even hedonistic

\footnotetext{
${ }^{51}$ See, e.g., Christine M. Korsgaard, The Relational Nature of the Good, in 8 OXFORD STUDIES In METAETHICS 1, 16-19 (Russ Shafer-Landau ed., 2013); cf. ARISTOTLE, NicomacheAn ETHICs bk. 10, ch. 5, 1175a23-1176a29, reprinted in 2 THE COMPLETE WORKS OF ARISTOTLE 1729, 1857-59 (Jonathan Barnes ed., W.D. Ross \& J.O. Urmson trans., 1984) (arguing that the pleasures accompanying different kinds of activity are themselves different in kind).
} 
utilitarians should acknowledge the heterogeneity of pleasurable feelings and the doubt it casts on the prospects of directly measuring quantities of pleasure.

For their part, Bentham's fellow utilitarians were ready to acknowledge about as much. They thought the measurement of well-being was not so much a matter of straightforward detection as it was a matter for considered reflection. Sidgwick, for example, conceded that having a feeling of pleasure is not akin to tasting something sweet. Pleasurable feelings seem a much more heterogeneous lot. He therefore proposed thinking of a person's good in terms of "desirable consciousness. ${ }^{, 52}$ John Stuart Mill had noted the heterogeneity of pleasurable feelings even earlier when he noted that different types of activities are accompanied by different kinds of pleasurable feelings. He made this observation while venturing the controversial claim that certain kinds of pleasant feelings contribute more than others to an individual's well-being-in virtue of their quality rather than just their intensity or other quantifiable attributes. ${ }^{53}$ Both of these utilitarians resisted the Benthamite thought that pleasure is a distinctive feeling with quantifiable intensity.

Although Sidgwick and Mill agreed that figuring out what makes someone better off requires a dose of reflection, they favored engaging in such reflection from somewhat different perspectives. Mill favored a more objective perspective, such as that of someone who has experienced all sorts of pleasures and so has insight into their true value. ${ }^{54}$ Sidgwick resisted this

\footnotetext{
${ }^{52}$ SIDGWICK, supra note 47, bk. 2, ch. 2, § 2, at 127 (7th ed. 1907); id. bk. 3, ch. 14, §§ 3-5, at 395-407.

${ }^{53}$ JOHN STUART Mill, Utilitarianism ch. 2, at 11-17 (13th ed. 1906).

${ }^{54}$ MiLl, supra note 53, at 12-17. David Brink goes so far as to argue that Mill is not really a hedonist at all: his concern was with the objective goodness of activities rather than the pleasurableness of mental states. David O. Brink, Mill's Deliberative Utilitarianism, 21 PHIL. \& PUB. AFF. 67, 72-76 (1992).
} 
approach, worrying that the experienced observer might be too much unlike the person whose well-being is at issue to reach an accurate judgment of the latter's propensity to take pleasure in different experiences. ${ }^{55}$ And so he advocated a much more subjective perspective for measuring the desirableness of a state of consciousness. ${ }^{56}$ But regardless of which perspective—-subjective or objective—one favors for estimating effects on well-being, I think there are many scenarios within the copyright context where neither of two available options seems overall more conducive to one's well-being than the other.

Compare prime examples of their respective art-forms: a brilliant composer's magnum opus, a first-rate sculptor's masterwork, a visionary film director's highest achievement, and so forth. Whatever particular examples qualify as your own personal favorites, could you rank them precisely according to the total amount of pleasurable feelings that use of them brings you? I certainly feel unable to do so in my own case. And it does not seem any easier to rank such works' effects on an individual's well-being using an objective measure of their quality. Perhaps the most discerning and trustworthy high-brow art critic would judge neither Mozart's music nor Michelangelo’s sculpture simply better than the other at improving a person's life. ${ }^{57}$ Neither are superlative artists the only ones whose work seems hard to rank in this way. It can likewise be hard to make precise comparisons of two things that give only moderately high amounts of pleasure-like a well-crafted

${ }^{55}$ SIDGWICK, supra note 47, bk. 2, ch. 3, § 7, at 148; see also id. bk. 1, ch. 7, § 2, at 94-95; id. bk. 2, ch. 1, § 1 at 121.

\footnotetext{
${ }^{56}$ Some hedonists would say that Sidgwick did not go far enough in the direction of subjectivity because one can find something desirable without desiring it. Roger Crisp therefore proposes evaluating experiences in terms of how enjoyable they are. ROGER CRISP, REASONS AND THE GOOD 103-11 (2006).

${ }^{57}$ Cf. Ruth Chang, The Possibility of Parity, 112 EтHICs 659, 659 (2002).
} 
piece of long-form journalism and a National League baseball broadcast-as well as two things that each give only modest amounts of pleasure-like a humdrum magazine story and an American League baseball broadcast. The same could be said of unpleasant copyrightable works.

Difficulties like these have often been discussed under the rubric of incommensurability. At times, philosophers have distinguished incommensurability, incomparability, rough equality, and parity, ${ }^{58}$ but such distinctions are of little importance here. The essential point is that the heterogeneity of the pleasurable feelings that alternative sets of copyrightable works would produce (or the heterogeneity of some other valuable feature that might be a basis for comparison) not infrequently makes it hard to believe one bundle better overall than an alternative. But such alternatives are not really equally good, either, because very slight improvements to one of them might still fail to establish its superiority. ${ }^{59}$ In this way, incommensurable alternatives are unlike two five-dollar bills.

But if two alternatives are of incommensurable value—or, symbolically, if $\mathrm{u}\left(x_{1}\right) \approx \mathrm{u}\left(x_{2}\right)$ then it is extremely difficult to compare aggregates of those alternatives and their kin because the incommensurability relation does not follow the same rules as equality, being less, and being greater. Recall bundles $A=\{a, b, c, d\}$ and $B=\{a, b, e, f\}$. Let us suppose that an individual derives incommensurable utilities from the use of $c$ and $e$, and incommensurable utilities from the use of $d$ and $f$. In other words, let us suppose $\mathrm{u}(c) \approx \mathrm{u}(e)$ and $\mathrm{u}(d) \approx \mathrm{u}(f)$. From these facts, as well as the fact

\footnotetext{
${ }^{58}$ See, e.g., Ruth Chang, Introduction to INCOMMENSURABILITY, INCOMPARABILITY, AND PRACTICAL REASON 1, 2, 4-5 (Ruth Chang ed., 1997).

${ }^{59}$ For an early appearance of this now-familiar argument, see Ronald B. de Sousa, The Good and the True, 83 MiND 534, 544-45 (1974).
} 
that $a$ and $b$ are found in each bundle, we might conclude $\mathrm{u}(A) \approx \mathrm{u}(B) .{ }^{60}$ Consider now a third possible bundle, $C=\{a, b, g, b\}$, such that $\mathrm{u}(e) \approx \mathrm{u}(g)$ and $\mathrm{u}(f) \approx \mathrm{u}(b)$. Suppose that this means that $\mathrm{u}(B) \approx \mathrm{u}(C)$. Because the incommensurability relation is intransitive, it does not follow, from $\mathrm{u}(A) \approx$ $\mathrm{u}(B)$ and $\mathrm{u}(B) \approx \mathrm{u}(C)$, that $\mathrm{u}(A) \approx \mathrm{u}(C)$. It could be true, for example, that $\mathrm{u}(A)>\mathrm{u}(C)$. To see this possibility, imagine that $c$ and $d$ are terrific compositions by Johann Sebastian Bach, that $e$ and $f$ are terrific sculptures, and that $g$ and $b$ are terrific compositions by Carl Philipp Emanuel Bach, which though terrific are slightly less so than his father's. The first bundle might outrank the third, then, even though both are incommensurable with the second. In this way incommensurability raises serious questions about the possibility of adding up amounts of utility derived from consuming individual goods in order to compare alternative bundles of such goods. At a minimum, if individual copyrightable goods regularly contribute incommensurable amounts to an individual's well-being, we should allow for the possibility that bundles of copyrighted goods routinely contribute incommensurable amounts to an individual's well-being. We cannot simply assume that, between practically any two proposed copyright policies, any individual would be made better off under one or the other or equally well off under either. The alternatives could easily be incommensurable or on a par instead.

Many utilitarians, however, deny that incommensurability poses a genuine threat. Perhaps, they concede, utility cannot be quantified through either direct detection or thoughtful reflection,

\footnotetext{
${ }^{60}$ This conclusion is too quick, though, if we do not assume the utility from each of these goods is independent of which other goods are included in the bundle. It would be better to allow for the possibility that one good's presence might alter the utility derived from other goods - as when, for example, one's enjoyment of a novel is increased (or diminished) by a film adaptation. But this source of complexity, which I set aside, simply reinforces my doubts about the possibility of adding up amounts of utility provided by individual copyrightable works.
} 
but it is enough for utilitarianism's purposes that individuals can still make a selection between any two options—even seemingly incommensurable ones. For such ability to choose indicates the chosen option appeared at least as good as the other, from the chooser's own subjective perspective. And then there will exist an ordinal ranking of all possible options in terms of what the individual would choose, and such a ranking would indicate, for any two possibilities, that the individual preferred one to the other or was indifferent between them. Moreover, under certain assumptions, we can even derive the strength of the individual's preferences using an ordinal ranking of this sort. ${ }^{61}$ Institutional utilitarianism's completeness, even in the face of supposed incommensurability, may depend on nothing more than the assurance that choice is always possible. ${ }^{62}$

This response fits well with a certain non-hedonist view of well-being, according to which an individual's well-being basically consists in getting what she desires rather than what feels good. Some are attracted to this conception of well-being over hedonism for free-standing reasons. Compared to hedonism, the preference-satisfaction conception of well-being easily allows us to account for the value outside of felt experience and so allows us to deny, for instance, that extremely pleasant delusions necessarily increase well-being. ${ }^{63}$ Of course, the preference-satisfaction conception is itself controversial, but let us set aside the (admittedly critical) question of whether

${ }^{61}$ John Harsanyi proposed one very well known derivation that built off earlier work by John von Neumann and Oskar Morgenstern. John C. Harsanyi, Cardinal Welfare, Individualistic Ethics, and Interpersonal Comparisons of Utility, 63 J. POL. ECON. 309 (1955).

${ }^{62}$ For a clear statement of this line of thinking, see Richard Craswell, Incommensurability, Welfare Economics, and the Law, 146 U. PA. L. REV. 1419, 1423-26 (1998).

${ }^{63}$ See, e.g., JAMEs GRIfFIn, WeLl-BeING 9-10 (1986) (discussing Robert Nozick's experience machine and a few more realistic examples). 
preference satisfaction provides a plausible criterion for well-being. After all, even if well-being as such does not consist in getting what one wants, it could still be the case that getting what one wants is a serviceable proxy for well-being. Or it could be that specific social institutions ought to be designed to provide people with they want. ${ }^{64}$ In a democracy, for instance, it seems that voting procedures should be designed to ensure citizens get the result most of them want. Arguably, copyright should also be designed to encourage production of works that cater to citizens' preferences. Whether or not that is right, though, I will assume it is for argument's sake. Even so, an institutional utilitarianism built around preference satisfaction cannot avoid incommensurability worries. However plausible the preference-satisfaction conception of well-being may be, the institutional utilitarian is not entitled to the assumption that most any two copyright options can be differentiated according to which contributes more to an individual's well-being.

In a way, the promise of complete ordinal rankings seems to handle incommensurability by stipulating it away. Insofar as it is the incommensurability relation's intransitivity that generates worries, preference-satisfaction accounts of well-being apparently avoid trouble by excluding the possibility of intransitive preferences: the "at least as preferable as" relation—customarily symbolized as $x_{1} \succsim x_{2}$-is assumed to be transitive because the individual is assumed to be rational. There are good reasons for this assumption. An individual who chose on the basis of an intransitive incommensurability relation might end up worse off by his own lights. Suppose, to return to our earlier example, that he traded his J.S. Bach recording for a roughly equally good sculptural replica, and then proceeded to trade his sculptural replica for a roughly equally good C.P.E. Bach

${ }^{64}$ See T.M. SCANLON, What We OWe TO Each Other 116-18 (1998). 
recording. Because (we are assuming) the recording of the son's composition stands somewhat inferior to the recording of the father's, this individual would end up worse off than he started. The transitivity assumption seems, at least at first glance, a nice idealization.

But the preference-satisfaction idealizations do not stop there. No one thinks that merely selecting one thing rather than another indicates anything about the selector's well-being. The game-show contestant who thinks it wise to choose "what's behind door number two" does not even slightly suggest that the prize behind door number one delivers less utility. On the other hand, if she knew something about the characteristics of the supposedly secret prizes, we might assume otherwise. For reasons like these the preference-satisfaction conception of well-being is built around informed preferences. This idealization is itself quite plausible and perhaps even indispensible for the preference-satisfaction conception's appeal.

Nevertheless, the assumption of adequate information raises a perplexing issue for us. In the intellectual property context, it is often useful information—such as knowing how to keep tomato plants alive in northern New England—whose contribution to well-being we seek to measure. And that raises a puzzle for the view that well-being should be measured by the choices an informed individual would make: How can such a person determine how much she desires information without possessing it already? Surely some conceivable ways of keeping tomato plants alive in a cool, overcast climate will hold greater appeal than others. And until the individual knows the details, her preferences will not be fully informed. But then the individual cannot make an informed choice to get that information instead of some alternative good without already possessing the information. On the informed preference-satisfaction conception of well-being, 
where the desirable thing is information, there simply is no fact about how much it contributes to an individual's well-being in advance of that individual's possession of the good. ${ }^{65}$

This problem does not seem as acute with tangible goods. Someone can more easily determine how much she would like to own a certain automobile in advance of having done so. Are copyrightable works more like information or automobiles? Much seems to depend on how specifically the copyrightable works are described to the person needing to make a selection. Imagine, for example, a choice between a musical composition and a book. Certainly this description of the alternative provides inadequate information for anyone who generally likes both music and reading. If it is further revealed that the composition is Beethoven's heretofore undiscovered Tenth Symphony, and the book is an unpublished Ph.D. dissertation written by someone obscure, that might be information enough for many people. Then again, it might not be. The individual who has actually experienced both works might decide the symphony was uncharacteristically bad and lost to history for good reason, while the dissertation exceeded initial expectations and proved brilliant. Having only a little bit of information about the options can lead an individual to make poor choices, even from her own subjective perspective, and this challenge seems to arise fairly often for artistic goods. How could one rank two different haikus without reading them? But if copyrightable works must be consumed, and so must exist, before an individual forms informed preferences yielding a complete ordering of the works produced under

\footnotetext{
${ }^{65}$ This observation is closely related to what Kenneth Arrow's "fundamental paradox in the determination of demand for information": information's "value for the purchaser is not known until he has the information, but then he has in effect acquired it without cost." KENNETH J. ARROW, Economic Welfare and the Allocation of Resources for Invention (1962), reprinted in ESSAYS IN THE THEORY OF RISK-BEARING 144, 152 (1971).
} 
alternative copyright policies, then ex ante there is no ideal copyright policy bringing the optimal set of works into existence. Even for one individual, there can be no complete ordinal ranking of works that might be created, but have not been yet.

It might be supposed that even under uncertainty, individuals could manage well enough ranking options according to expected utility—an ex ante estimate of how much utility they will likely produce. Unfortunately even determinations of expected utility require subjective probability estimates, though, and it is not clear individuals would always possess subjective probability estimates that would help establish expected utilities from not-yet-existing intellectual goods. Predicting the quality of an aesthetic experience is extremely hard if one has not yet had it. Good art, for example, can affect the way one thinks or feels in unexpected ways. And in general the more innovative the potential intellectual good, the more likely the uncertainty is unquantifiable ex ante. ${ }^{66}$ In short, informed preferences do not promise fully determinate guidance for intellectual property policymakers, simply because the policymakers' actions are conceptually prior to the typical individual's informed preferences.

Perhaps a response to this difficulty lies in further idealization. It is widely acknowledged that informed preferences are not exactly the right indicators of individual well-being because the individual as he actually is might not have the same preferences as his fully informed self. There may be some hard truths, for instance, that the individual would prefer not to learn in the first place. And so the real-world individual might not be best off if he gets exactly the things his

\footnotetext{
${ }^{66}$ See generally FrANK H. KNIGHT, RISK, UNCERTAINTY, AND PROFIT 19-20 (1921) (distinguishing between measurable "risk" and unmeasurable "uncertainty").
} 
idealized counterpart wants. ${ }^{67}$ What the preference-satisfaction conception of well-being really needs, then, is the ordering that the fully informed version of the individual forms on behalf of the real-world version, taking into account only the real-world version's attitudes and characteristics. Perhaps a similar refinement might restore the possibility of preference-based ex ante standards for intellectual property policymaking. Perhaps the idealized version of the individual—who not only understands his real-world counterpart perfectly but also has experience with the entire universe of possible intellectual goods—could devise a complete ordering that reflected the real-world version's preferences. To be sure, this idealized ranking might not ever be known by real-world policymakers who need its guidance, and epistemically inaccessible complete rankings might not hold much appeal for someone who thought institutional utilitarianism attractive partly because of its apparent guarantee of determinate guidance. Whatever the epistemic barriers, though, the institutional utilitarian might still insist that this sort of idealized ranking in principle permits the comparison of any two intellectual property policies in terms of their effects on an individual's well-being.

I do not believe, however, that even this otherworldly version of the preference-satisfaction conception of well-being succeeds. The difficulty is that preferences are shaped to a considerable degree by the policies that precede them. Consider an example from U.S. copyright law, which as we have seen prohibits the unauthorized creation of new works that transform or are otherwise derived from preexisting copyrighted works. ${ }^{68}$ Copyright's "derivative works" right prohibits, among many other things, unlicensed cinematic adaptations of copyrighted novels, as well as

\footnotetext{
${ }^{67}$ See, e.g., GRIFFIN, supra note 63, at 11.

${ }^{68}$ See 17 U.S.C. $\S \S 101,106$ (2006).
} 
unlicensed film sequels. It seems quite possible and perhaps even likely that this law affects individuals' tastes for the hugely successful movie franchises built around Harry Potter, James Bond, Marvel and D.C. comic superheroes, and J.R.R. Tolkien's Middle Earth. Perhaps films from franchises like these would be less popular if just anyone could create his or her own adaptations of the relevant characters and stories. Or, to the contrary, perhaps a relaxation in copyright law would result in an outpouring of new creativity in this area and the relevant characters and stories would become more popular. I do not know exactly how preferences would be affected by a change in copyright law's derivative works right, but I suspect some change would occur. If so, then how the law handles the issue of derivative works at time $t_{1}$ affects individuals' preferences later at $t_{2}$. Suppose that at $t_{2}$, an individual's ranking of two copyright bundles is $A \gtrsim B$ if the law has created a derivative works right at $t_{1}$, but $B \gtrsim A$ otherwise. In such circumstances, how can the institutional designer possibly base a decision on the derivative works right on the individual's preferences for the movies and other works in bundles $A$ and $B$ ? Those preferences depend on the institutional designer's decision, and so cannot even in principle provide a basis for that decision. ${ }^{69}$

If the preference-satisfaction conception of well-being has a way of handling this problem, I do not know what it is. ${ }^{70}$ The possibility of an omniscient observer with unlimited epistemic access

\footnotetext{
${ }^{69}$ Cass Sunstein has previously made this point in the context of environmental regulation, but I think the point is even more forceful in the intellectual property context. See Cass R. Sunstein, Endogenous Preferences, Environmental Law, 22 J. LEGAL STUD. 217, 234-35 (1993). I also think it applies to hedonist theories-including Roger Crisp's, which would have individuals rank experiences in terms of how enjoyable they are-since the quality of one's experiences may be affected by public policy. See CRISP, supra note 56, at 110.

${ }^{70}$ Some economists do acknowledge that preferences should sometimes be treated as endogenous variables. See, e.g., GARY S. BECKER, ACCOUNTING FOR TASTES 20-22 (1996); KAPLOW \& SHAVELL, supra note 13, at 413-18. But I have found no explanation of how it is even theoretically possible to base a policy decision on preferences when the relevant preferences are shaped by the policy decision.
} 
to the individual's personal characteristics and the entire universe of possible intellectual goods is no help to us here. For now the idealized version must make a comparison between two potential versions of his real-world self, who have different preferences. This comparison seems more interpersonal than intrapersonal, ${ }^{71}$ unless the individual happens to have higher-order preferences at $t_{1}$ that favor having, at $t_{2}$, one set of first-order preferences rather than the other. Higher-order preferences, however, seem to fall within the province of reflective deliberation, and worries about incommensurability might resurface when the individual considers being the type of person who will later tend to prefer franchise films or, rather, the type of person who will later prefer selfcontained ones. But we can even set that issue aside because there is simply no guarantee that at $t_{1}$ the individual has developed a forward-looking, higher-order preference: perhaps she is a toddler at $t_{1}$, when we are designing our copyright laws. I suppose the defender of the preference-based theory of well-being might insist that an idealized version of this toddler would be able to determine whether the real-life toddler would prefer to have pro- or anti-franchise preferences later in life. But such insistence may not be justified. Nor is it obvious what it would mean then to claim we were still talking about an actual person's preferences.

For these reasons, institutional utilitarians are not entitled to the assumption that any two intellectual property policies can be ordered according to the goodness of their effects on a single individual's well-being. There could easily be significant indeterminacy in our rankings of the effects of intellectual goods' existence on an individual's well-being, regardless of whether our

\footnotetext{
${ }^{71}$ For doubts about the possibility of interpersonal well-being comparisons using only the criterion of preference satisfaction, see John Broome, Can There Be a Preference-Based Utilitarianism?, in Justice, Political LiBeralism, AND UtilitARIANISM: THEMES FROM HARSANYI AND RAWLS 221, 232-37 (Marc Fleurbaey et al. eds., 2008).
} 
conception of well-being is based on informed preference-satisfaction, hedonism, or some more objective standard. Now throughout this section, I have been considering the simple case of just one individual's well-being, and of course institutional utilitarianism is concerned with levels of well-being throughout a much larger population of many individuals. But this simplification does not, so far as I can see, change the conclusion, unless the utilitarian can establish that aggregating individual utility functions into a social welfare function would erase the indeterminacy found within the former. If my doubts are well-founded, it is entirely possible that one proposed intellectual property policy is neither better nor worse than another proposal in virtue of their respective effects on overall well-being. Whatever else one might say about it, institutional utilitarianism should not be thought appealing because it promises some definite right answer to any policy question. That promise is empty.

\subsection{JUSTIFYING SOCIAL INSTITUTIONS}

One may remain reluctant to give up on the idea that practically any two options can be ranked, one over the other, on the ground that such a ranking seems crucial for justified choice. Thus Donald Regan argues that, regardless of how things appear to us, there could not be fullfledged incommensurability or rough equality between possible courses of action:

Choice is based on reasons. Choice between two specific goods must be based on reason to prefer one of the goods to the other. Where there is no adequate reason for preference, there can be no real choice. A decision to go one way rather than the 
other will be something that happened to the agent rather than something she did. $^{72}$

On this suggestion, unless the agent has reason to choose option 1 rather than option 2, she cannot fully identify with her choice of option 1 as a rational being. Although Regan's concern is intelligibility rather than justifiability, one might suppose that an action's unintelligibility to the person who engaged in it would raise doubts about its justifiability. I will contest both claims in this section, first by defending action's intelligibility in the absence of decisive reasons for the chosen alternative and then by sketching a picture of justification within the context of intellectual property institutions.

Consider a mundane example of an ordinarily intelligible action: cutting a round cake. A person could perform this action in a great many ways. This is true even if we set aside alternative times, venues, and tools for the cake-cutting, and focus on procedure alone. The cake-cutter could choose between a theoretically infinite number of radii for making the first cut, or could make diametric cuts as one might do when cutting a pizza, or could make vertical and horizontal cuts in a grid-like pattern. Assuming the cake-cutter follows standard practice and makes a radial cut, he could then proceed in a clockwise or counter-clockwise fashion, by turning his knife or the plate, creating large or small slices or some of each, leaving the cut pieces in place or removing them as he goes, and so on. The possibilities are endless, but somehow he muddles through. What should we make of this?

\footnotetext{
${ }^{72}$ Donald Regan, Value, Comparability, and Choice, in InCOMMENSURABILITY, INCOMPARABILITY, AND PRACTICAL REASON, supra note 58, at 129, 144.
} 
One thing we ought not to conclude is that the cake-cutter must feel alienated from what he has just done unless he had reason to prefer his chosen procedure to every one of the countless alternatives. In the typical case, all that he needs to understand are reasons that support his choice to cut the cake-such as would be provided if the cake had to be eaten by several people. He does not need to understand reasons for cutting the cake exactly one way rather than another, although he may understand reasons against cutting the cake in some particular ways. If this interpretation of the example is correct, it suggests that action-explanations need not be contrastive in a fundamental way. To make an action intelligible to oneself, it is very often enough to answer the question "Why $\varphi$ ?" without necessarily being able to answer such questions as "Why $\varphi$-ratherthan- $\chi$ ?" and "Why $\varphi$-rather-than- $\psi$ ?" and so on. Thus the self-aware Buridanian ass should not be in any way mystified if instead of perishing from starvation he opts for one of the equally attractive hay options. The ass can perfectly well explain why he moved toward and consumed the pile of hay and nothing more needs explaining. ${ }^{73}$ The ass need no more be able to explain why he selected that pile of hay rather than the other (given that they appear equally choice-worthy to him) than the cake-cutter must be able to explain why he made his cuts counter-clockwise rather than clockwise. These examples might seem fairly insignificant in the grand scheme of things, but the basic point remains even if we move on to more weighty decisions between incommensurable

\footnotetext{
${ }^{73}$ Joseph Raz argues, I think correctly, that "the most typical exercise or manifestation of the will is in choosing among options that reason merely renders eligible." Joseph Raz, Incommensurability and Agency, in INCOMMENSURABILITY, INCOMPARABILITY, AND PRACTICAL REASON, supra note 58, at 110, 111. But he seems to think something else is needed to explain why the agent chooses one option and not another: reason, he says, merely "sets a range of eligible options before agents, who choose among them as they feel inclined, who do what they want to do or what they feel like doing." Id. at 127 (emphasis added). I would resist the suggestion that something non-rational is needed to make the agent's choice intelligible. (And I am also unsure about Raz's claim that "the will plays a role in human agency separate from that of reason." $I d$.).
} 
options-such as a choice between multiple attractive careers. And so it is entirely possible to agree with Regan that, for creatures like us, intelligible choice is essentially connected to reasons, and yet disagree with him that it is essentially connected to comparative reasons. The second claim requires a further step — such as positing choice-between as the basic species of choice-and it is not clear we should take it.

In my view, matters are much the same with justifiability. If there are reasons for performing an action, we should not presume it is something less than justified until we can show that it is more justified than alternatives. Yet many accounts of what makes an action justifiedincluding the maximization approach favored by some consequentialists-seem to conceive of deliberation as a competitive tournament, the ultimate aim of which is to crown a single winner. ${ }^{74}$ To be sure, plenty of actions are supported by reasons and nevertheless unjustified. It may be impermissible to pursue an admittedly worthy goal in a way that requires depriving some person of something he urgently needs and could easily be provided, or that treats him as a mere means, or that gratuitously inflicts large amounts of pain on him. In some cases, it is even the nature of the available alternatives that disqualifies one option from serious consideration: one should not pick an option that is inferior to another option in every significant respect; perhaps one should not pick an option that, though good, will lead to much worse consequences than another good

\footnotetext{
${ }^{74}$ Satisficing consequentialism, by contrast, permits any choice among options that have "good enough" consequences, which allows for the possibility of many justified choices. One of the main problems of satisficing consequentialism, however, is that it permits choosing an inferior (but still good enough) option when a superior (also good enough) option could easily be chosen instead. I would suggest preserving satisficing consequentialism's rejection of the winner-take-all model of deliberation while accepting widespread incommensurability and abandoning consequentialism.
} 
option. And when one acts akratically—for example, by choosing to perform an action that one believes one has conclusive reason not to perform—-the decision may be not only unjustifiable but also less than fully intelligible. Yet none of these observations undermines my claim here. They merely suggest that practical deliberation characteristically narrows down the range of choiceworthy alternatives in a variety of ways. But that the deliberating agent can and should eliminate many options from consideration does not entail that ideally she would eliminate all the options except one, as the winner-take-all model of deliberation would seem to imply.

We should approach the task of justifying social institutions, including intellectual property law, with the same mindset. When some ask whether our intellectual property law is justified, they seem to be asking whether it is as good as it could be. The result is likely to be unsatisfying if for no other reason than we do not possess the ability to identify the characteristics of the optimal intellectual property law. But if we understand the issue of justification differently, in the way I have been proposing, we need not be troubled by either this uncertainty or by the possibility I stressed in the last section - that there may not be such a thing as the optimal intellectual property law. To justify the basic features of copyright and patent laws, for example, it would be at least presumptively enough to establish that providing the relevant incentives to produce the relevant sorts of intellectual goods furthers the interests of many. ${ }^{75}$ Of course, it might be possible to establish that failing to offer some sort of special incentive for developing intellectual goods would have intolerable consequences. In that case, the absence of intellectual property law or some

\footnotetext{
${ }^{75}$ If the laws treated anyone objectionably, however, a presumptive justification would not be enough.
} 
functional substitute would be unjustified. But I do not believe justifying intellectual property law requires showing that failing to provide special incentives is objectionable.

Even if the basics of copyright and patent law are justified on grounds that the utilitarian would find palatable, though, that does not mean that every detail must be justified on such grounds. Take, for an example, one particular doctrine of copyright law, known as "fair use," which is a defense against an accusation of infringement available in certain circumstances to someone who has copied a portion of a copyrighted work without authorization. ${ }^{76}$ Unauthorized copying of copyrighted material is most likely to be privileged as fair use when it puts the material to a new purpose, such as by parodying it, providing commentary, or critiquing it. ${ }^{77}$ If, as I assume, there are very good reasons to allow a parodist or commentator or critic to be able to use another's work for free and without having to obtain permission, and no compelling reasons for a contrary rule, this doctrine is easily justified. Indeed, having something like a fair use doctrine seems obligatory, given the rest of copyright law, because a rule requiring critics or parodists to obtain permission before reproducing parts of works they are criticizing or parodying would be insufficiently attentive to their and the rest of society's interests in free expression. But my main point here is that whether or not fair use doctrine is a necessary part of any justifiable copyright law, we need not settle the issue as an institutional utilitarian would. We need not, for instance, seek to determine whether the social value of the negative commentary the doctrine induces and avoidance of various transaction costs will increase overall well-being enough to offset the decrease in well-being that

\footnotetext{
${ }^{76} 17$ U.S.C. $\S 107$ (2006).

${ }^{77}$ See, e.g., Campbell v. Acuff-Rose Music, Inc., 510 U.S. 569, 579 (1994).
} 
would arise if individuals were dissuaded from producing new copyrightable works for fear of unbridled negative commentary.

One last illustration of the approach I am recommending can be found in a recent dispute over the patentability of human DNA. ${ }^{78}$ It has long been the rule that someone who discovers a law or product of nature, or a mathematical truth, cannot obtain a patent over that discovery as such, but can only claim patent protection for new, useful, and nonobvious applications of it. ${ }^{79}$ The utilitarian analysis of this subject matter restriction would measure the social benefits of incentivizing the research by means of intellectual property rights against the social costs of limiting access to basic mathematical and scientific truths. While there are clearly good reasons to incentivize genetic research, it is at least arguable that there are decisive reasons against a proposal that granted someone exclusive rights to various uses of genetic information contained within another person's own body. One may think that individuals have a compelling enough interest in being free to examine and to authorize others (such as doctors) to examine the properties of their own bodies that no broad prohibition on that sort of examination could ever be justified-for such reasons, some might even suppose we have rights over our genetic materials that a gene patent would violate. Or, more modestly, one might simply think that these interests, when combined with alternative adequate means of incentivizing genetic research—such as direct grants—are together enough to eliminate gene patents from consideration. As with the preceding example, I

\footnotetext{
${ }^{78}$ See Ass'n for Molecular Pathology v. Myriad Genetics, Inc., 133 S. Ct. 2107 (2013).

79 See, e.g., Mayo Collaborative Servs. v. Prometheus Labs., Inc., 132 S. Ct. 1289, 1293-94 (2012).
} 
mention this aspect of intellectual property law not to stake a firm position but to illustrate how a nonutilitarian approach to intellectual property's justifications might proceed.

\subsection{Functionalist Justification And Private Legal Rights}

In this chapter I have been arguing for a functionalist justification of intellectual property law, particularly copyright and patent, based on society's interest in the availability of copyrightable expressive works and patentable inventions. But if the central features of intellectual property law are justified because of this sort of diffuse, society-wide interest rather than the interests of the intellectual property owners, it is not clear how the law could generate rights that are held by intellectual property owners against those who are obligated.

Like "interests," the word "rights" has several familiar uses, and this fact makes it somewhat tricky to use the word well in philosophical discussions. For my purposes, it is helpful to distinguish between thick and thin conceptions of rights. As Joel Feinberg stressed, rights can justify a special sort of insistence: people seeking favorable treatment have "sturdy objects to 'stand upon" if they can insist they have a right to be treated in the sought-after way. ${ }^{80}$ For other authors, such as Ronald Dworkin and Robert Nozick, rights speak in favor of the relevant acts (or omissions) with a distinctive forcefulness and cannot be overridden on certain grounds. ${ }^{81}$ And then there is perhaps a special category of rights that have fundamental importance in life as we know it

${ }^{80}$ Joel Feinberg, The Nature and Value of Rights, 4 J. VALUe INQUiRY 243, 252 (1970).

${ }^{81}$ See, e.g., RONALD Dworkin, TAKING RightS SERIOUSLY xi-Xv (1978) (endorsing a conception of rights as trumps, based on equal concern and respect); ROBERT NOZICK, ANARCHY, STATE, AND UTOPIA 28-33 (1974) (endorsing a side-constraints conception of rights, based on the inviolability of persons). 
and are held universally throughout our species. The notion of "human rights" is, alongside Dworkin's notion of rights as “trumps," Nozick's notion of rights as “side constraints," and Feinberg's notion of rights as “moral furniture,” an example of what I am calling a thick conception of rights. All these notions make rights out to have considerable practical implications in virtue of their substantive content.

According to a thin conception of rights, by contrast, a right need not have such implications. The paradigm here is Wesley Hohfeld's conception of rights "in the strictest sense," which are often called claim-rights. ${ }^{82}$ These rights have only two modest implications: (1) one or more persons is under a duty to engage in or abstain from certain conduct; and (2) engaging in or abstaining from the specified conduct is owed by the duty-holder(s) to the right-holder(s). Hohfeld famously defined claim-rights in terms of correlative duties toward the right-holder:

Rights Defined in Terms of Duties: $R$ has a right against $D$ that $D \varphi$ if and only if $D$ has a duty toward $R$ to $\varphi^{83}$

This definition does not imply anything about the strength or importance of the duty-holder's obligation to the right-holder or about what the obligation allows the right-holder to do. For all the definition says, the duty might be overridden by countervailing considerations or, even if not overridden, still rather unimportant in the grand scheme of things. Indeed, the duty could potentially have so little importance that the right-holder would be acting oddly, perhaps even inappropriately, if she were to insist that the duty-holder fulfill it. For this reason, it might strike

\footnotetext{
${ }^{82}$ Wesley NeWComb Hohfeld, Fundamental Legal ConCEPtions AS APPLied IN JUdicial Reasoning 36 (Walter Wheeler Cook ed., 1919).

${ }^{83}$ See id. at 38.
} 
us as strange to describe all claim-rights as rights simpliciter, especially in view of the frequency with which thick conceptions of rights make appearances in everyday speech. Nonetheless my concern here is with this thin conception of rights, and whenever I speak of rights in what follows, I am referring to Hohfeld's term of art and nothing more. What I am interested in exploring is not how intellectual property laws generate rights with serious heft, but rather how they generate rights at all.

Another way of raising the issue is to ask whether copyright and patent law deserve to be classified as part of private law if they are principally justified by the functionalist considerations I defended earlier in this chapter. The distinction between private and public law dates back a long time-at least to ancient Rome. ${ }^{84}$ It is perhaps hinted at even earlier, in Aristotle's contrast between corrective justice and distributive justice. ${ }^{85}$ Private law, according to what I will call the classical understanding, is centrally concerned with the duties that private actors have toward one another-and correlatively, the rights private actors have against one another-whereas the focus of public law is on the duties and rights of the state or community as a whole. ${ }^{86}$ On this traditional view, the fields of contract, tort, property, and unjust enrichment are core examples of private law subjects, while constitutional, administrative, tax, and criminal law make up the bulk of public law. If we want to move beyond a list of standard examples, though, it is crucial to explore the concept

\footnotetext{
${ }^{84}$ See, e.g., BARRY NicholAS, AN INTRODUCTION TO ROMAN LAW 2 (1962). Of course, the duties in each area of the law are also supplemented by related Hohfeldian powers and immunities.

${ }^{85}$ See ARistotle, Nicomachean Ethics bk. 5, chs. 3-4, 1131a10-1132b20, reprinted in 2 The Complete WORKS OF ARISTOTLE 1729, 1785-87 (Jonathan Barnes ed., W.D. Ross \& J.O. Urmson trans., 1984).

${ }^{86}$ See, e.g., 2 John Austin, LeCtures on Jurisprudence 785-86 (Robert Campbell ed., 5th ed. 1885); Thomas ERSKINE HOLLAND, THE ELEMENTS OF JURISPRUDENCE 127-28 (12th ed. 1916).
} 
of directed duties further. In order to understand what makes private law what it is, we need to understand what makes a duty such that one private actor has it toward another private actor rather than toward the state or the community as a whole or nobody in particular.

In relatively recent times, the connection between private law and a specific sort of directed duty/correlative right was drawn in the famous tort case, Palsgraf v. Long Island Railroad Co ${ }^{87}$ The dispute began when an employee of the defendant railroad company attempted to help a hurrying man onto a moving train and in the process knocked a package out of the man's hands. The package fell between the train and platform, and its combustible contents eventually exploded with enough force to topple a penny scale onto Helen Palsgraf, the plaintiff. ${ }^{88}$ The employee's actions, according to the court, amounted at most to negligent treatment of the man, not Ms. Palsgraf herself, even though those actions caused her injuries. Writing for a narrow majority on New York state's highest court, Judge Cardozo explained that a plaintiff suing for negligence "must show ... 'a wrong' to herself; i.e., a violation of her own right and not merely a wrong to some one else, nor conduct 'wrongful' because unsocial, but not 'a wrong' to any one. ${ }^{„ 89}$ Thus, the negligence tort requires that the plaintiff show not merely that the defendant did wrong; she must show that the defendant wronged her. Or, in duty terminology, ${ }^{90}$ the negligence plaintiff must prove not simply a

\footnotetext{
${ }^{87} 162$ N.E. 99 (N.Y. 1928).

${ }^{88} I d$.

${ }^{89}$ Id. at 100 .

${ }^{90}$ In my view, which I think is consistent with Palsgraf, relational wrongs are simply infringements of a right. Using Hohfeld's correlativity thesis, see supra note 83 and accompanying text, relational wrongs can also be defined in terms of breaches of directed duties:
} 
breach of some legal duty by the defendant, but rather a breach of a directed duty to the plaintiff herself. ${ }^{91}$ Whether or not the railroad company had breached its duties, Palsgraf could not prevail because it had not breached any duty that it had toward her. This case is sometimes read in support of the doctrine that tort plaintiffs only have standing to sue a defendant who has breached a duty toward them specifically. ${ }^{92}$ But more generally, the case shows how tort law's focus is on duties that are directed to particular right-holders.

In this respect, tort law is like other areas of private law but quite unlike criminal law, as the Palsgraf court itself hinted. ${ }^{93}$ To be sure, many crimes are committed through acts that breach the agent's duties to a particular person. Criminal violence, for example, often wrongs discrete victims. But even where there is this overlap—as with the laws of civil and criminal trespass, conversion and theft, and false imprisonment—-torts and crimes come apart, with the result that the crime can be prosecuted by the state even though no tort action is ever brought by the wronged private party, and vice versa. And it is no essential feature of crimes that they violated duties directed to particular people. So-called victimless crimes are denominated as such because they are thought not to wrong any particular person. Standard examples from this controversial

Relational Wrongs Defined in Terms of Rights: $D$ would wrong $R$ by $\varphi$-ing if and only if $R$ has a right against $D$ that $D$ not $\varphi$.

Relational Wrongs Defined in Terms of Duties: $D$ would wrong $R$ by $\varphi$-ing if and only if $D$ is under a duty to $R$ not to $\varphi$.

${ }^{91}$ See Palsgraf, 162 N.E. at 101 (saying that the victim "sues for breach of a duty owing to himself").

92 See, e.g., Benjamin C. Zipursky, Palsgraf, Punitive Damages, and Preemption, 125 HARV. L. REv. 1757, 1768-69 (2012).

${ }^{93}$ Palsgraf, 162 N.E. at 101. 
category are laws against certain types of gambling, drug use, or sexual activity. Less peripheral are crimes that apparently wrong the state as such or the community as a whole-for instance, laws against treason, tax fraud or evasion, and littering on public property. There may in fact be some dispute about whether the duties of criminal law are directed duties at all. Instead of specifying conduct that the duty-holder owes to the state or community, some have suggested criminal law duties are "merely monadic" - mandating behavior that is not really owed to anyone. ${ }^{94}$ Whatever the merits of this suggestion, it is clear that in directing the conduct of private individuals, criminal law and private law diverge in their degree of concern with directed duties to particular private persons: such duties are private law's central concern, but not criminal law's.

This understanding of private law, which is really just the classical understanding, has become the dominant view among legal philosophers. ${ }^{95}$ But it is hardly the only possibility. One could, like certain devotees of law and economics, understand private law simply as the domain within which private individuals bring civil claims. ${ }^{96}$ This alternative understanding, however, would say that the private individual who brings a civil lawsuit to press a matter of public concern is operating squarely within the bounds of private law. In the United States, to take an example, an

\footnotetext{
${ }^{94}$ Michael Thompson, What Is It to Wrong Someone? A Puzzle About Justice, in REASON AND VALUE: Themes FROM THE MORAL PHILOSOPHY OF JOSEPH RAZ 333, 344 (R. Jay Wallace et al. eds., 2004); see also Stephen Darwall, Bipolar Obligation, in 7 OXFORD STUDIES IN METAETHICS 333, 347 (Russ Shafer-Landau ed., 2012) ("The criminal law is to the moral law as the law of torts is to the $\mathrm{di}[\mathrm{k}] \mathrm{a}[\mathrm{io}]$ logical order of bipolar moral obligations.").

${ }^{95}$ See, e.g., ERnest J. WeInrib, The Idea of Private LaW 123 (rev. ed. 2012); Jules L. Coleman, Doing away with Tort Law, 41 Loy. L.A. L. Rev. 1149, 1157 (2008); John C.P. Goldberg \& Benjamin C. Zipursky, Rights and Responsibility in the Law of Torts, in RightS AND PRIVATE LAW 251, 261 (Donal Nolan \& Andrew Robertson eds., 2012); Arthur Ripstein, As If It Had Never Happened, 48 WM. \& MARY L. Rev. 1957, 1964 n.21 (2007).

${ }^{96}$ See, e.g., SteVEn Shavell, Foundations of ECONOMic ANALYsis of LAW 5 (2004) (claiming that specific "areas of the law are said to be private because they are enforced by the bringing of suits by private parties").
} 
ordinary citizen may bring a civil suit to enforce certain federal environmental standards. ${ }^{97}$ Yet someone who brings a "citizen suit" is not seeking redress for substandard conduct toward herself in particular. She is, rather, deputized to act in the public interest as a "private attorney general." 98 The same is true even if she is offered financial incentives to bring her suit. For instance, federal law authorizes private persons to bring qui $\operatorname{tam}^{99}$ civil actions against those who commit fraud in their financial dealings with the federal government, promising such persons a share of the spoils if the suits they initiate succeed. ${ }^{100}$ If these citizen suits do not seem to belong within the category of private law, then private law should not be defined simply as law enforced by private parties.

Some legal theorists, however, have no problem doing violence to ordinary conceptions of private law because they find the concept itself pernicious. Many self-styled "realists" claim private law is simply "public law in disguise" and say no one should think otherwise. ${ }^{101}$ To a large degree, they are worried that approaching private law without public interests in constant view will encourage excessive individualism—-possibly including absolutist commitments to private property

\footnotetext{
${ }^{97}$ See, e.g., 42 U.S.C. $§ 7604$ (2006) (permitting citizen-suit enforcement of the Clean Air Act's emission standards).

${ }^{98}$ Assoc. Indus. of N.Y. State, Inc. v. Ickes, 134 F.2d 694, 704 (1943) (Frank, J.) (coining the phrase).

${ }^{99}$ This phrase is short for "qui tam pro domino rege quam pro se ipso in hac parte sequitur." E.g., Vt. Agency of Nat'l Res. v. United States ex rel. Stevens, 529 U.S. 765, 768 n.1 (2000). The Latin may be translated, "who pursues this action for our Lord King as much as for himself."

${ }^{100}$ See 31 U.S.C. $\S 3730$ (permitting enforcement of the False Claims Act through qui tam actions).

${ }^{101}$ Leon Green, Tort Law Public Law in Disguise (pts. 1 \& 2), 38 Tex. L. Rev. 1, 257 (1959-1960); see also G. EDWARD WHITE, TORT LAW IN AMERICA 150 (expanded ed. 2003) (describing the "antidoctrinal connotations" of the claim that tort law is public law).
} 
rights and contractual freedom. ${ }^{102}$ In Leon Green's formulation, the law ought to reflect the fact that 'We the People' are a party to every lawsuit and it is our interest that weighs most heavily in its determination. ${ }^{, 103}$ It is deeply undesirable, the legal realist line of argument goes, to have an area of law that professes to focus on private rights instead of broader social concerns. ${ }^{104}$ Any theoretical account of private law that takes its alleged privateness seriously is likely to produce substantively bad law. Now I think this shot at private law is a misfire: tying private law to duties owed toward particular private persons does not obviously limit its substance, and does not limit it to some form of libertarian individualism. ${ }^{105}$ Still, there are good reasons not to ignore the realist's worries entirely, because private law theorists who adopt the classical understanding of their subject have not satisfactorily explained the relationship between that understanding and private law's substantive content.

A couple prominent private law spokesmen, moreover, have implied that the correlativity of private law's directed duties and rights actually does rule out basing private law's doctrines on certain normative considerations. Ernest Weinrib claims that tort law cannot be sensitive to

102 Cf. John Henry Merryman, The Public Law-Private Law Distinction in European and American Law, 17 J. PUB. L. 3, 13 (1968) (describing various ways that political ideology might affect a legal theorist's attitude toward private law).

${ }^{103}$ Green, supra note 101, at 1. The legal realist critique of private law occasionally combines normative and descriptive elements: judges of disputes between private parties should focus on the public's interests in the outcome, and cannot do otherwise. See id. at 2 . I will be focusing on the normative element, which is easier to comprehend, in the hope that my response to it will also indirectly respond to the descriptive element of the realist critique by making clearer the relationship between public interests and private rights.

${ }^{104}$ For a recent, rhetoric-laced articulation of the realist argument, see Michael L. Rustad, Torts as Public Wrongs, 38 PEPP. L. REV. 433, 495 (2011).

${ }^{105}$ Cf. Arthur Ripstein, Tort Law in a Liberal State, 1 J. TORT L., no. 2, June 2007, at 11 (explaining that libertarianism is not the only alternative to the legal realist claim that private law is public law in disguise). 
society's interests in affording compensation to the blamelessly injured and deterring those who would put others at risk. He believes these interests are at odds not only with each other but also with tort law's overarching concern with the bipolar relationship between duty-holder and rightholder. And so if compensation and deterrence were both among tort law's goals, tort law would be incoherent and unjustifiable. ${ }^{106}$ Likewise, Weinrib says, "facilitation of commercial activity, not being a correlatively structured consideration (as corrective justice requires), is a poor justification for property and contract." ${ }^{107}$ In a similar vein, Arthur Ripstein claims that when courts consider social goals instead of exclusively focusing on the relationship between plaintiff and defendant, they engage in reasoning that is "defective" according to private law's internal standards. ${ }^{108}$ Thus these authors suggest that basing private law on certain kinds of normative considerations, especially the interests of society as a whole, is inappropriate if private law's core concern is with the duties that private persons owe one another. ${ }^{109}$ Weinrib in fact makes an even stronger claim about the relationship between the bipolar or correlative form of private law norms and their substantive content: private law is necessarily Kantian in its substance. ${ }^{110}$ Recall from Chapter 3 that in Kant's legal philosophy, actions are evaluated only in terms of their compatibility with everybody's

${ }^{106}$ See WEINRIB, supra note 95, at 38-42. This seems to me to be what Weinrib is saying, anyway.

${ }^{107}$ Ernest J. Weinrib, Private Law and Public Right, 61 U. ToRonTo L.J. 191, 202 (2011).

${ }^{108}$ Arthur Ripstein, Civil Recourse and Separation of Wrongs and Remedies, 39 FLA. ST. U. L. REV. 163, 176-77 (2011).

${ }^{109}$ Cf. Gregory C. Keating, Personal Inviolability and “Private Law," 1 J. TORT L., no. 2, June 2007, at 4 (noting that the Ripstein/Weinrib account of private law has no room for "enterprise liability with its emphasis on systemic risk engendered by large scale social activities").

${ }^{110}$ See, e.g., WEINRIB, supra note 95, at xvii (claiming that any coherent conception of private law liability presupposes "the Kantian ideas of agency, freedom, and rights"). 
freedom. ${ }^{111}$ If the classical understanding of private law really is committed to a Kantian normative framework, the implications for private law's substance could be radical.

But Weinrib and Ripstein's claims are controversial, even among those who firmly agree with them that private law is centrally concerned with duties private persons owe to one another. Irrespective of their more controversial claims, it is fair to say too much mystery surrounds the relationship between the form and substance of private law's rights and duties. Anyone who would defend classical accounts of private law should be able to explain the conception of directed duty around which the account is built. Since at least Justice Holmes, a common legal realist complaint has been that the use of moralized concepts within discussions of the law breeds great confusion. ${ }^{112}$ In order to stem such complaints, those of us who do rely on such concepts should make clear that at least we know how we are using them.

I raise these abstract jurisprudential issues because our present subject matter makes them particularly pressing. Intuitively, intellectual property law seems clearly to belong with the exemplars of private law—especially property and tort—rather than with public law subjects. ${ }^{113}$ The individual who brings an intellectual property infringement lawsuit is apparently seeking redress for violation of her own right. She does not seem to be merely enforcing compliance with the law in the shoes of some public official, nor even suing for the sovereign as much as for herself.

${ }^{111}$ See Immanuel Kant, The Metaphysics of Morals 6:230-31 (1797), reprinted in Practical Philosophy 353, 387 (Mary J. Gregor ed. \& trans., Cambridge Univ. Press 1996).

${ }^{112}$ See O.W. Holmes, The Path of the Law, 10 HARV. L. REV. 457, 459-62 (1897).

${ }^{113}$ There are, of course, intellectual property crimes, but these comprise only a fraction of intellectual property law as a whole. 
But if the intellectual property claimant is not principally acting as the state's deputy as a private attorney general or qui tam litigant, ${ }^{114}$ we should be able to explain why that is so. To that end, the remainder of this section considers three possible explanations and concludes that none is quite successful. It is, in fact, surprisingly difficult to explain why copyright and patent duties are duties toward the persons who are said to be intellectual property owners.

First, one might turn decisively in the direction of morality and suppose that the directedness of legal duties arises because those duties correspond to independently existing directed moral duties. In recent years, a number of moral philosophers have supposed that it is a very basic normative fact about some (but perhaps not all) of our moral duties that they are directed toward particular persons. ${ }^{115}$ The private law theorist might call attention to private law duties' routine correspondence to moral duties that are themselves directed duties and that would exist whether or not the private law duty did. Consider a simple example. If, regardless of what positive law says, $D$ morally owes it to $R$ not to injure $R$ in a range of circumstances, then there is an easy explanation of why $D^{\prime}$ s legal duty not to injure $R$ in more or less the same range of circumstances would be a directed duty. The legal duty's directedness would derive from the directedness of the moral duty that it lines up with. The obvious limitation of this approach is that it presupposes there is a corresponding directed moral duty in the first place. But the second and third chapters of this dissertation were devoted to showing that core areas of copyright and patent

\footnotetext{
${ }^{114}$ See supra notes $97-100$ and accompanying text.

${ }^{115}$ I have in mind especially Thompson, supra note 94, at 338-40; and Darwall, supra note 94, at 337-39. Another possible example can be found in F.M. KAMM, INTRICATE ETHICS 239 (2007). Ripstein also seems attracted to this picture of directed duties. See, e.g., Arthur Ripstein, ForCE AND FreEdom 379 (2009).
} 
law do not simply codify independently existing moral duties. In this respect, I argued, copyright and patent are rather unlike trademark. So while this correspondence solution might explain why central disputes within trademark law involve directed duties, it would not explain why copyright and patent belong to private law. And for all we know, there could be other legal duties that intuitively fall within private law but do not closely track independently existing directed moral duties.

A second possible strategy would be to look to a general theory of rights for insight. There are a handful of such theories on offer in the literature, ${ }^{116}$ which has been growing ever since H.L.A. Hart's famous criticisms of the "benefit" theory of rights that is attributed to Jeremy Bentham. ${ }^{117}$ According to the benefit theory, a person has a right when she is the intended beneficiary of another person's duty. Hart noted that simply being the intended beneficiary of someone's duty is insufficient for having a right against that person. To prove his point, he used an example in which a promise is made in order to benefit a third party. ${ }^{118}$ According to Hart, if I promise another person that I will look after his mother while he is traveling, it is he who has the right against me, not his mother. And that is true even though she is the intended beneficiary of

\footnotetext{
${ }^{116}$ For a helpful, up-to-date overview, see Rowan Cruft, Introduction to Symposium: Rights and the Direction of Duties, 123 EтHICS 195, 196-98 (2013).

${ }^{117}$ Bentham does not directly advance the benefit theory of rights in any one place, but Hart and others have found the theory scattered throughout various passages in Bentham's work. See, e.g., H.L.A. Hart, Bentham on Legal Rights, in 2 OXFORD EsSAYS IN JURISPRUDENCE 171, 176-78 (A.W.B. Simpson ed., 1973); David Lyons, Rights, Claimants, and Beneficiaries, 6 AM. PHIL. Q. 173, $173 \&$ n.1 (1969).

${ }^{118}$ H.L.A. Hart, Are There Any Natural Rights?, 64 PHIL. Rev. 175, 180-81 (1955); see also Hart, supra note 117, at 195.
} 
the duty that my promise creates. ${ }^{119}$ So the identity of the right-holder must depend on something other than the intended receipt of benefits. ${ }^{120}$ Much of the resulting debate has centered on identifying exactly what makes it the case that somebody has a right. Rights theory may therefore be able to explain why intellectual property seems to involve directed duties. Let us then consider the two most prominent contenders.

Joseph Raz's "interest” theory of rights is much in the spirit of Bentham's benefit theory but seems to avoid the third-party beneficiary counterexample. According to Raz, someone who is capable of having rights in general has a particular right if and only if she has an interest that provides a sufficient reason for holding another person to be under a duty. ${ }^{121}$ On the interest theory, then, the right-holder's interest grounds or justifies the right. ${ }^{122}$ In the third-party beneficiary case, the interest that grounds the promissory duty is not the mother's interest in being looked after. By hypothesis, that interest would not justify any such duty on its own. To the contrary, the duty is justified by some interest of the son-an interest in being able to make arrangements for the future with confidence, perhaps. So understood, the interest theory avoids

${ }^{119}$ To make this example work, it helps to make a few extra assumptions: first, that I have not, even implicitly, made the promise to the mother as well; and second, that my making the promise to her son did not induce her and her son to abandon making alternative arrangements for her care.

${ }^{120}$ Even Matthew Kramer, who defends a modified version of the benefit theory, does not claim that being an intended beneficiary is sufficient for having a right. See, e.g., Matthew H. Kramer, Some Doubts About Alternatives to the Interest Theory of Rights, 123 ETHICS 245, 247 (2013).

${ }^{121}$ Joseph RaZ, The Morality of FreEdom 166 (1986). Note that Raz defines "interest" narrowly so as to include only aspects of the would-be right-holder's well-being.

${ }^{122}$ In his initial presentation of the interest theory, Raz seeks to preserve the ambiguity in the phrase "holding [another person] to be under a duty," which may mean something like either "judging a person to have a duty" or "imposing duties on him." Id. at 172. I will focus on the latter possibility, which Raz seems entirely comfortable with in his later discussion. See Joseph Raz, Rights and Individual Well-Being, 5 RATIO JURIS 127 (1992). 
the third-party beneficiary problem, but is incapable of explaining copyright and patent rights. For the interests of intellectual property owners are not sufficient to ground most of the duties imposed by copyright and patent law. Those duties are instead grounded by the interests of the general public, as I described earlier in this chapter.

Yet Raz offers a second version of his interest theory that enables some rights to be justified primarily by the interests of persons who are not the right-holders. He thinks many free speech rights, for example, might be largely grounded by the public's interests. ${ }^{123}$ Consider a journalist's right not to be punished by her government for refusing to reveal her sources. The journalist's own interest in not being coercively pressured into revealing her sources might pale in comparison to the government's interests. Raz suggests that the journalist's interest justifies her robust free speech right only because it has extra instrumental value that derives from its relation to the public's very strong interest in a free press: through protecting the journalist's personal interest, the state thereby serves that interest of the general public. ${ }^{124}$ Whether or not this move is satisfactory, ${ }^{125}$ it would explain copyright and patent rights only at the cost of delivering the wrong results in the private attorney general example. In such a case, the particular plaintiff presumably has some interest in the defendant's compliance with the particular environmental standards, but not enough of one to justify the standards all on its own. Nevertheless, through protecting the plaintiffs interest, the law serves everybody's interest in environmental protection. Thus the

\footnotetext{
123 See RAZ, supra note 121, at 179.

${ }^{124}$ See id. at 179-80, 247-49; Raz, supra note 122, at 134, 137-38.

${ }^{125}$ For worries, see KAMM, supra note 115 , at $245-46$.
} 
plaintiff's interest seems to warrant the defendant's legal duty by virtue of its relation to others' interests, in the way that Raz envisions. But the defendant who fails to comply with the standards seems in the first instance to be wronging the whole community, and wronging this particular plaintiff only derivatively - that is, insofar as the plaintiff is a member of that community. And if that is correct, the second version of Raz's interest theory does not identify right-holders accurately.

According to Hart's own "will" or "choice" theory of rights, by contrast, $R$ has a right against $D$ just in case $R$ 's choice to demand or waive $D$ 's duty determines whether $D$ in fact has that duty. ${ }^{126}$ This proposal fares better with the private attorney general example, since although the private attorney general can demand compliance by bringing his lawsuit, he is powerless to waive the defendant's statutory duties. The will theory also seems helpful in the intellectual property context because intellectual property owners characteristically have the power to grant licenses, which make it legally permissible to engage in conduct that would otherwise constitute infringement. Critics of the will theory often deny that having the power to waive someone's duty is a necessary condition for having the correlative right since some rights might be inalienable and correlative to duties that cannot be waived by anyone. ${ }^{127}$ For my purposes, it is more important to recognize that having that power is certainly not a sufficient condition for having the right. Imagine someone who enters into a contract with some small corporation. It may be the case that a

${ }^{126}$ See, e.g., Hart supra note 117, at 191-92.

127 See, e.g., D.N. MacCormick, Rights in Legislation, in LAW, MORALITY, AND SOCIETY 189, 195-99 (P.M.S. Hacker \& J. Raz eds., 1977). 
particular officer of the corporation has the power to relieve the promisor of his contractual obligation, and maybe also the power to sue if the promisor breaches. But even if the officer has the power to sue, it is clear that she does so only to vindicate the corporation's right. The contractual obligation is still owed to the corporation as a whole, not to the officer, even though she has this power. If this example or a similar one ${ }^{128}$ works, the will theory of rights does not solve our problem here.

Let us then examine a third strategy for identifying directed legal duties that takes a step back from rights and other highly moralized concepts. John Goldberg and Benjamin Zipursky, who have done more than anyone else to defend the connection between directed duties and private law, say that legal directives are "relational" when they "enjoin people not to treat others in certain ways" or "require them to treat others in certain ways." ${ }^{129}$ Perhaps a directed legal duty is just a legal duty that requires or forbids certain sorts of treatment of others. More formally, we might distinguish between monadic actions, which can be described without making reference to a second party, and dyadic actions, which cannot. For instance, although one can speak or move all by oneself, one cannot defame or batter without implicating another person. Non-tortiously, solo dance is a possibility, but it takes two to tango. Although Goldberg and Zipursky do not explicitly propose that we understand directed legal duties in terms of the logical form of the relevant actions, doing so fits well with the contrast they draw between "simple legal directives" that take the form "For all

\footnotetext{
${ }^{128}$ For an alternative, consider an example from Frances Kamm (with credit to Peter Graham), who imagines a judge with the power to relieve someone of his duty to another person. KAMM, supra note 115, at 243.

${ }^{129}$ John C.P. Goldberg \& Benjamin C. Zipursky, Torts as Wrongs, 88 TEX. L. REv. 917, 945 (2010).
} 
$x, x$ shall not $A$ " and "relational directives" that take the form "For all $x$ and all $y, x$ shall not do $A$ to $y . " 130$ It seems plausible to characterize the unauthorized reproduction or development of copyrighted or patented works as dyadic actions — on account of the copyright or patent owner whose authority the infringer lacks - and so this third approach might appear at first blush to explain why copyright and patent belong within private law.

As an account of directed legal duties, however, this proposal is over-inclusive. Some violations of relational legal directives cannot plausibly be described as violations of duties owed to particular individuals. Consider laws against the unauthorized practice of law. The actions these laws prohibit are dyadic: given that it is generally permissible to represent oneself, describing the conduct that is forbidden cannot be done without making reference to a second person-the client - who receives the impermissible representation or advice. Yet I think it would be counterintuitive to suppose some non-lawyer who violates such a law without any dishonesty, perhaps even to the overall benefit of the second party, has violated a duty toward him or her. If that is so, then for a legal duty to be a directed duty, it is not sufficient that it have the logical form of a relational legal directive.

Perhaps the relational legal directive account can be salvaged by adding a further condition, perhaps one that takes it cue from the interest theory of rights. For instance, suppose that violating the relational directive risks harm to the second party. It may indeed be odd to think that someone who provides highly competent legal advice, while openly acknowledging she is not authorized to

\footnotetext{
${ }^{130}$ Id.; see also Goldberg \& Zipursky, supra note 95, at 260-61 (describing simple legal directives as "enjoin[ing] conduct without reference to persons other than the target(s) of the directive").
} 
practice law, violates any duty owed the client. But if the legal advice proves beneficial only because the unauthorized practitioner gets lucky, we might think otherwise on account of the significant risk.

It seems to me that this restriction still does not help the proposed account avoid overinclusiveness. Imagine that legislators in a society without poverty prohibit taking bets on sporting events because they think that gambling is a vice and that targeting bookies is a good way of lessening it. Although accepting a bet is a dyadic action that subjects the second party to foreseeable risk, it is still hard to see how the unlawful action violates a duty to the bettor, at least in some easily imagined cases. The same would hold true even if she actually loses the bet. Unless the bookkeeper actually mistreats bettors in some way—for example by being dishonest or manipulative- she does not seem to violate any duty to them, regardless of the legal duties she violates. This example suggests to me that the prospects for a non-moralized account of directed legal duties are rather bleak. Whether a duty is toward some particular individual feels like a fundamentally moral question.

Consider, alternatively, some hybrid of the relational legal directive account and Hart's will theory of rights. Perhaps a legal right exists whenever the law both tells the duty-holder not to treat another person in a particular way and authorizes that other person to bring a civil lawsuit against the duty-holder if he or she violates the duty. Such an account may survive the counterexamples I have been putting forward, but it would make legal rights and moral rights quite different phenomena. Generally it seems an open question whether having a moral right entails having a Hohfeldian power to obtain legal redress from someone who violates it. In the next 
section, I will propose an alternative account of legal rights that does not depend on the existence of a power to enforce them.

\subsection{DERIVING RightS FROM InSTITUTIONS}

The last section worried that functionalist justifications for intellectual property seem to underwrite laws of the wrong kind. That is, if intellectual property law is actually grounded by the interests of society as a whole, it looks more like public-minded regulation enforced by wellincentivized private litigants than a private law body of right/duty correlatives. Yet this worry raises a broader question, which is not just a subject for legal theorists, about the relationship between interpersonal morality and social institutions: How can certain behavior demanded by a social institution be owed to a particular person when that person's interests and claims do not provide sufficient reason for the institution's demand? The aim of the present section is to take a step back from the law to answer this broader question.

The question was raised several decades ago as a concern about Rawls's account of the obligation to keep promises. Rawls says that the general principle of fairness (or "fair play") can explain why it is impermissible to break a promise. According to the principle of fairness, someone who has voluntarily accepted benefits from a just institution must support the institution in the manner specified by its rules. ${ }^{131}$ In freely making a promise, Rawls claims, the promisor intentionally makes use of the social institution of promising-presumably pursuing some sort of present or future benefit and having previously benefited from others' promise-keeping. So,

\footnotetext{
${ }^{131}$ John RAwLS, A THeory OF Justice $§ 18$, at 96 (rev. ed. 1999).
} 
assuming that the institution of promising is a just one, any promisor who voluntarily accepts benefits from it is obligated to follow its rule that promises must be kept (unless special excusing conditions are met). ${ }^{132}$ But if fairness to the institution's supporters is what grounds promissory obligation, fulfilling our promises seems to be something that we owe to everybody who uses and supports the promising institution that has benefited us and that continues to benefit society as a whole. As Rawls himself says when introducing the principle of fairness, obligations that derive from it are normally owed to all "those who are cooperating together to maintain the arrangement in question." 133 The duty to fulfill our promises, however, seems a clear-cut example of a directed duty, where the particular person to whom we owe fulfillment is the promisee, the person to whom the promise was made. ${ }^{134}$ So even assuming that Rawls's fairness-based account of promissory obligation is true as far as it goes, it does not seem to be a complete account because it leaves unexplained the fact that promises create duties toward promisees in particular.

This concern seems justified, and in my view would still be justified if, in order to deter socially harmful promise-breaking, the institution gave promisees financial incentives to seek redress from anyone who broke a promise to them. But we should not be too quick to draw sweeping conclusions from this sort of worry. In particular, we should not conclude that whenever the specific content of an institution's rules is based on something other than individuals' interests or claims, the rules do not set out directed duties toward those individuals. The wrongness of such

\footnotetext{
${ }^{132} I d . \S 52$, at $304-05$.

${ }^{133} I d . \S 18$, at 97.

${ }^{134}$ This concern about Rawls's account is pressed by A.I. MELDEN, RIGHTS AND PERSONS 89-90 (1977) and SCANLON, supra note 64 , at 316.
} 
a conclusion can be seen by extending a line of thought Rawls advanced in his early work on social practices.

While exploring the possibility that utilitarianism might provide a more appealing justification for social practices (such as punishing criminals) than for particular actions falling under such a practice (such as punishing a particular criminal), Rawls proposed what he called the practice conception of rules. ${ }^{135}$ Under the practice conception, rules demanding certain behavior are not simply reports of what behavior has worked well in the past but, on the contrary, are "logically prior" to the behavior they demand in an important way. Rawls writes:

given any rule which specifies a form of action (a move), a particular action which would be taken as falling under this rule given that there is the practice would not be described as that sort of action unless there was the practice. In the case of actions specified by practices it is logically impossible to perform them outside the stagesetting provided by those practices, for unless there is the practice, and unless the requisite properties are fulfilled, whatever one does, whatever movements one makes, will fail to count as a form of action which the practice specifies. What one does will be described in some other way. ${ }^{136}$

Rawls offered a few baseball examples to illustrate this idea. Without the game of baseball and its rules, a person could run ninety feet in a straight line but could not steal a base, and a person could unsuccessfully try three times to club a ball thrown toward her but could not strike out. The institution of baseball plays an indispensible part in making those physical movements the sort of actions they are. ${ }^{137}$

\footnotetext{
${ }^{135}$ John Rawls, Two Concepts of Rules, 64 PHIL. Rev. 3, 24 (1955).

${ }^{136} I d$. at 25 .

${ }^{137}$ Id.; see also John R. Searle, How to Derive "Ought” from "Is," 73 PHIL. REv. 43, 54 (1964) ("A man hits a home run only given the institution of baseball; without the institution he only hits a sphere with a stick.").
} 
We might therefore follow John Searle in distinguishing between the regulative and constitutive aspects of rules: rules are regulative when they state that certain activity is permitted (or not), and rules are constitutive when they state that certain activity that falls under an institutionalized practice counts as a specific type of action. ${ }^{138}$ An example of a regulative rule in baseball would be the prohibition against running the bases in a clockwise direction in order to confuse the defending team. ${ }^{139}$ An example of a constitutive rule would be the provisions explaining that running the bases counter-clockwise constitutes running them in the forward direction, or the provisions explaining what it is to steal a base. ${ }^{140}$ As Searle noted, many rules constitute and regulate. ${ }^{141}$ For example, in its normal formulation, the rule against reverse baserunning has constitutive and regulative dimensions because the regulated behavior-running the bases in the reverse order—cannot be described in a way that avoids reference to the game of baseball. Many rules can be accurately formulated in multiple ways, some of which emphasize their regulative dimension alone ("Such-and-such-movement with such-and-such motives is forbidden"), and some of which bring out a constitutive dimension as well ("Such-and-suchmovement with such-and-such motives constitutes reverse base-running, which is forbidden").

${ }^{138}$ See, e.g., Searle, supra note 137, at 55.

${ }^{139}$ OfFiCIAL BASEBAll RULES 7.08(i), at 67 (2013), available at http://mlb.mlb.com/mlb/downloads/y2013/ official_baseball_rules.pdf; see also LAWRENCE S. RITTER, THE GLORY OF THEIR TIMES 43-45 (new enlarged ed. 1984) (recounting Germany Schaefer's early-twentieth-century decision to steal first base from second to induce a throw from the catcher so that his teammate on third could then steal home).

${ }^{140}$ See OfFicial BASEBALl RULES, supra note 139, 7.02, 10.07, at 60, 96-98.

${ }^{141}$ In light of the fact that some rules both constitute and regulate, we may observe that the claim that an institution generates a duty to $\varphi$ could imply either (1) that if the institution did not exist, the duty-holder would be permitted not to $\varphi$ (but perhaps would $\varphi$ anyway) or (2) that if the institution did not exist, it would not be possible for the duty-holder to $\varphi$ because the institution is prior to $\varphi$-ing in the way Rawls and Searle discuss. 
One further distinction is essential for our discussion. Canonical formulations of some constitutive rules make them out to be internally constitutive: they state conditions under which a certain activity falling under an institutionalized practice counts as a specific type of action that exists only within the institution. Actions governed by internally constitutive rules are posterior to the institution in the way that stealing a base, striking out, and hitting a home run are posterior to the game of baseball. But not every act that falls under a practice falls under it exclusively. Many actions that are regulated and partially constituted by social institutions can also be accurately described as actions that would have been possible even without the institution. And so a rule that has an externally constitutive formulation states conditions under which a certain activity falling under an institutionalized practice counts as a specific type of action that can exist outside the institution, even if the institution does not. Hence actions governed by externally constitutive rules need not stand posterior to the institution. Like the line between constitutive and regulative rules, the line between internally and externally constitutive rules can be crossed by changes in formulation: it is possible to formulate some rules as either internally or externally constitutive.

A few more baseball examples will clarify this distinction between internally and externally constitutive rules. Take for instance the rule establishing what happens when a runner on the batting team runs all the bases and safely touches home plate. ${ }^{142}$ Although many of the ways one could describe this runner's actions depend on the game of baseball, one upshot of the rule in question is that in so acting the runner scores. And the game of baseball is not prior to scoring,

\footnotetext{
${ }^{142}$ See Official Baseball Rules, supra note 139, 4.09(a), at 34.
} 
because it is possible to score whether or not baseball exists. ${ }^{143}$ Thus the rule on scoring is externally constitutive at least on this formulation. Another baseball rule makes it possible for a player on the home team to hit a walk-off home run when he hits a home run that puts his team ahead in the score during the ninth inning or extra innings. ${ }^{144}$ So formulated, the rule is internally constitutive because baseball is prior to the act of hitting a walk-off home run. But the rule can also be formulated as externally constitutive since hitting a walk-off home run constitutes a way of winning a game for one's team, and one can act under the latter description whether or not baseball exists.

With these distinctions in hand, let us get back to our main topic by considering one final baseball rule that has both externally constitutive and regulative dimensions. According to baseball's official rules, it is impermissible for pitchers to apply any "foreign substance" to the ball. ${ }^{145}$ Pitchers who do so in order to get unnatural movement from the ball are accused of doctoring their pitches and thus engaging in a forbidden action-type that is internal to the game of baseball. But such pitchers are also said to be cheating, and the game of baseball is not prior to cheating as such. So the rule that says it is cheating to apply a foreign substance to the ball is regulative (insofar as it prohibits certain acts) and externally constitutive (insofar as it establishes that certain acts within baseball amount to cheating). For my purposes, the crucial point is that those who play competitive games have a general obligation toward their opponents to refrain from

\footnotetext{
${ }^{143}$ Even scoring a run is possible without the game of baseball, thanks to the game of cricket.

${ }^{144}$ OfFicial BASEBALl RULES, supra note 139, 4.11(c), at 36.

${ }^{145}$ See id. 8.02(a)(2)-(6), at 74 .
} 
cheating, ${ }^{146}$ and so violating baseball's idiosyncratic rules can amount to a violation of this extrainstitutional directed duty. Since players owe it to their opponents not to cheat, someone who violates a game's rules in a way that qualifies as cheating violates a duty owed to a particular person, whether or not the conduct required by the rule is grounded in that person's own interests or claims. Baseball's rule against doctoring pitches strikes me as clear evidence for this claim, since any justification for the rule would likely be based on the rulemakers' notions of what makes a more enjoyable game overall. ${ }^{147}$ Even though the rule against doctoring pitches seems to be justified on impersonal grounds like these, violations of the rule can still be violations of a duty toward the rule-violator's opponent in particular because of the standing duty not to cheat. ${ }^{148}$

But I do not mean to make my argument stand or fall with my interpretation of a single baseball rule. There are, I believe, countless examples of general standing duties to particular persons that are made determinate by institutional arrangements that are not grounded by those persons' own interests or claims. Such institutional arrangements change what the duty-holder is doing and what the likely consequences will be. Take rules of etiquette, whose specific content is fixed by social conventions. It is hard to believe that individuals' pre-conventional interests or

\footnotetext{
${ }^{146}$ To be sure, cheating can wrong others, too, including others who play the game or the game's fans. My claim is only that cheating wrongs the cheater's specific opponent in a distinctive way.

${ }^{147}$ Too many other aspects of the game are designed to make the batter's job difficult to permit the conclusion that the rule exists principally out of concern for the batter's own interests or claims.

${ }^{148}$ By contrast, there was no standing duty toward promisees identified in Rawls's account of promising. It was the account's lack of any standing directed duty, rather than its focus on society's interests, that made it impossible to interpret as explaining promisees' unique rights.
} 
claims demand that etiquette's rules have the specific content that existing rules have. ${ }^{149}$ It is easier to believe that every person has a claim to be treated with respect and courtesy—simply in virtue of his or her status as a person, perhaps - and that sometimes conventions of etiquette settle what conduct constitutes disrespectful or discourteous treatment in a given social context. ${ }^{150}$ Many such rules seem arbitrary, and for those there may be little to be said to justify their having the specific content they do. Other rules of etiquette may be justified primarily because they function better from the community's point of view than salient alternatives. In academic lectures and other formal presentations, for instance, the applicable rule of etiquette usually dictates that the audience's questions and comments be held until the end of the speaker's planned remarks. One can imagine an alternative norm allowing certain interruptions that, if well publicized in advance, would not impermissibly infringe upon the speaker's interests or claims. But that alternative might make these events less edifying overall than a practice of keeping questions until the end. So perhaps we observe the rule against any interruption in order to obtain such diffuse benefits. Nevertheless, given that the rule exists, violating it arguably constitutes violation of a directed, standing duty to show the speaker courtesy or respect in addition to whatever wrong it would be against the group as a whole.

We can now put games and good manners aside and turn back to positive law, the social institution that concerns us most. As in the previously discussed institutions, law's regulative

\footnotetext{
${ }^{149}$ Some imaginable rules, of course, would be ruled out as inherently incompatible with pre-conventional norms of equality or dignity.

${ }^{150}$ See Sarah Buss, Appearing Respectful: The Moral Significance of Manners, 109 ETHICS 795, 796-97 (1999).
} 
components can also be externally constitutive in a way that implicates our extra-institutional standing duties. Drivers, I take it, have a standing duty toward those they encounter on the roads not to drive recklessly. Surely some of what constitutes reckless driving does so whether or not traffic laws forbid it. Considering the brute facts alone, a person with good judgment knows that driving modern automobiles at extremely high speeds or under the influence of mind-altering substances would be reckless. In other cases, however, what constitutes recklessness depends on what the law says. The content of some of the relevant laws, like that of certain rules of etiquette, seems more or less arbitrary. For instance, legislators writing on a blank slate could justifiably decide either that cars should drive on the left side of the road or on the right. Yet as soon as they select one side over the other and the rest of society begins to respond appropriately, driving on the opposite side becomes highly dangerous and impermissible in normal circumstances. Many other legal decisions, perhaps even most, are based on reasons of one kind or the other. Even when those reasons do not show special concern for the safety of those who share the roads, however, the provisions they support may determine when one motorist wrongs another through recklessness. Imagine that decisions about who has the right of way at particular intersections are guided primarily by the goal of avoiding traffic slowdowns. Even though such decisions are not directly guided by safety concerns, disobeying such laws is very often reckless and a clear violation of the disobedient driver's duties toward those he has placed in danger. Violating traffic laws can constitute an action that wrongs particular people, regardless of the nature of those laws' justification. 
The same can be said, I claim, about violations of intellectual property laws. In the last two chapters, I have argued that core provisions of those laws-those that prohibit unauthorized reproduction, development, and distribution of copyrighted or patented works—cannot be justified on the grounds that they help intellectual property owners get what they are already due. Yet those provisions nevertheless give rise to rights because they implicate a standing directed duty toward intellectual property owners: a duty not to deny others their legitimate opportunities for material gain. This duty may look somewhat familiar. The Lockean duty not to interfere with others' labor, which I discussed at length in Chapter 2, is really just a more concrete version of the standing duty I am now discussing - a natural version, as it were. In Locke's state of nature, the earth's physical resources are initially free for the taking, provided that taking them would not deprive others of comparable opportunities, so that people can make use of those resources to gain the necessities and conveniences of life. What Locke described as labor was simply taking advantage of this opportunity, which was a legitimate opportunity for material gain, in my terms, because it did not harm others in any significant way. ${ }^{151}$ Interfering with laborers' use of what they have taken denies them such opportunities and is impermissible, I explained, because it harms them without justification.

In the real world, political arrangements and other social institutions constantly affect our opportunities for material gain, principally via addition. Intellectual property ownership, as defined

\footnotetext{
${ }^{151}$ Recall, however, that Locke further insisted that someone who takes commonly owned resources only to waste them wrongs others, even though such takings do not in any obvious way harm them so long as the enough-and-asgood proviso is respected. If one accepts this part of Locke's argument, some opportunities for material gain in the state of nature would not be legitimate ones even though they do not harm others.
} 
by positive law, constitutes an additional opportunity for material gain beyond what is found in the state of nature. Our laws are designed not only to enable innovators to offset their costs, but also to turn a profit. Someone who engages in copyright or patent infringement simply to avoid having to compensate copyright or patent owners would therefore deny them an opportunity to reap material rewards from their innovative activities. Yet this account forces us to consider the extent to which intellectual property opportunities are legitimate ones, such that denying those opportunities would wrong the intellectual property owners who are meant to have them. Two sorts of worry arise.

The first touches upon a very large question within political philosophy. What authority does the state have to bestow opportunities for material gain on select members? One can easily imagine objectionable opportunities of this sort, like the biblical publican who can amass great personal wealth collecting more than just the taxes actually owed the state. ${ }^{152}$ Intellectual property opportunities are certainly better than that: they serve private interests for the sake of serving those of society as a whole, and no one who is able and willing to forego the access to copyrighted or patented works that requires permission has to contribute anything to intellectual property owners. Moreover, intellectual property opportunities are available to anyone who meets the statutory requirements, not just a few specially privileged groups or individuals. Yet even if intellectual property opportunities are distributed fairly on paper, within a particular social context-especially one in which other goods are not distributed fairly — these opportunities might not be available as

\footnotetext{
${ }^{152}$ Cf. Luke 19:1-10.
} 
widely as they ought to be. And in such a context, opportunities that would be legitimate in ideal conditions might be illegitimate in actual ones.

The second sort of worry is narrower, at least in one obvious respect. Instead of raising general questions about intellectual property opportunities, one could ask whether those opportunities are compatible with the interests and claims of everyone else given the specific form that they take. In my view, these are exactly the types of questions we should be asking about individual intellectual property doctrines. And if we reject intellectual property utilitarianism (as opposed to functionalism), we cannot ignore these questions by assuring ourselves that the form intellectual property opportunities presently take maximize social welfare. Take for example, the fact that copyright owners' opportunities for material gain are shaped in a way that enables them not just to obtain reasonable compensation for infringing uses of their copyrighted work, but also to keep infringing uses of their copyrighted work from ever occurring. ${ }^{153}$ Copyright owners thus have significant power over the expressive freedom of anybody who would use their copyrighted work in a manner classified as infringing to express his or her own thoughts. Whatever its merits, a critic might claim that this power is insufficiently respectful of the non-owner's freedom of speech. ${ }^{154}$ And wielding this power in order to extract an exorbitant sum from someone wanting to use a copyrighted work for expressive purposes might even be viewed as capitalizing on an illegitimate opportunity for financial gain.

153 See 17 U.S.C. §502(a) (2006) (empowering courts to grant injunctions for the prevention of copyright infringement).

154 See, e.g., Mark A. Lemley \& Eugene Volokh, Freedom of Speech and Injunctions in Intellectual Property Cases, 48 DUKE L.J. 147 (1998) (making this argument about preliminary injunctions in the context of U.S. constitutional law). 
I only mention such concerns without attempting to rebut them, for that would take us too far afield. One cannot tackle the broader concern without a sound understanding of what distributive justice requires, and one cannot tackle even the second, narrower concern about copyright without a sound understanding of what freedom of expression demands. Since I have not attempted to dispel all the possible concerns, my conclusion is a conditional one: the portions of intellectual property law that are justified as socially beneficial incentives give rise to intellectual property rights to the extent that the opportunities for material gain that they create can themselves be adequately justified. But this conclusion still provides an explanation of how such intellectual property rights are possible. 


\section{INTELLECTUAL PROPERTY PLURALISM}

It is tempting to look for a justification for intellectual property through either the lens of natural rights or the lens of utilitarianism. Both ways of viewing the subject propose to make it intelligible to us in terms of a single purpose, although of course they offer competing portraits of that purpose. In the former case, intellectual property is preoccupied with securing what properly belongs to individuals and, in the latter case, with promoting the good of society as a whole. Because of their disagreement about intellectual property's fundamental purpose, these two accounts are regarded as diametrically opposed. But having scrutinized natural rights and utilitarian accounts of intellectual property in the preceding chapters, I have come to reject the either/or mindset they pressure us to adopt. Instead of assuming that intellectual property is justified either as a matter of natural rights or on utilitarian grounds, we should accept a pluralist account of intellectual property's justifications that incorporates what is most appealing in both the natural rights and utilitarian accounts. Intellectual property pluralism avoids the limitations of the natural right and utilitarian perspectives and allows for a richer understanding of the relationship between intellectual property rights and our intellectual property institutions.

Natural rights-type justifications of intellectual property ownership do well in highlighting the perspective of those individuals who create intellectual goods, but they run the risk of 
overemphasizing that perspective or of undervaluing the perspective of those whom intellectual property laws place under duties. In particular, natural rights accounts of intellectual property can proceed too quickly from a justification of physical property ownership to a justification of intellectual property ownership, disregarding the differences in the ways that intellectual property and physical property laws affect the relevant normative interests given the differences in the nature of intellectual and physical goods. In Chapter 2, I stressed how Lockean approaches to intellectual property rights are especially susceptible to this danger. A physical property owner's interests in material gain are greatly imperiled by others' unauthorized use of her physical property because such unauthorized use routinely interferes with the owner's own use of her property. But in focal cases of intellectual property, especially works of creative expression and inventions, others' unauthorized use of the property generally does not interfere with the owner's own use of her property. ${ }^{1}$ On the other hand, unauthorized use of trademarked symbols that confuses consumers does interfere with the trademark owner's ability to use the symbol to communicate with the consuming public. And so our discussion of Lockean arguments for intellectual property rights indicated that different intellectual property doctrines may have different justifications. Locke's arguments against interference work pretty well in justifying central trademark doctrines but not those of copyright or patent law. The pluralist account of intellectual property that I am defending forsakes a unified theory of intellectual property not only by relying on a plurality of normative

\footnotetext{
${ }^{1}$ Or, more precisely, the only uses of a copyrighted work or patented invention that infringers routinely interfere with are uses that presuppose the existence and justifiability of intellectual property rights, such as using intellectual property as a source of licensing revenue. This sort of interference cannot be the basis of a natural rights-type justification for copyright or patent law without begging the question.
} 
considerations, but also by advancing different justifications for different areas of intellectual property law.

Taking some cues from Kant, Chapter 3 considered another possible natural rights-type justifications for intellectual property ownership. This discussion went beyond the preceding chapter on Locke's labor theory by identifying another type of interest of intellectual property owners that is not reducible to Lockean interests in material gain. These other interests are interests in controlling one's own actions and, relatedly, in having a public reputation that accurately reflects the actions one has chosen to do. I argued against a recent interpretation of Kant's account of physical property ownership, according to which any unauthorized use of another's property wrongfully limits that person's freedom by conscripting her into the pursuit of ends that she has not chosen for herself. But, drawing on Kant's own writing about copyright, I argued that there are particular ways of using intellectual property that unjustifiably violate the intellectual property creator's interest in having control over her actions and/or reputation. In particular, falsely claiming credit for someone else's work or describing someone else as responsible for choices that she did not in fact make would disregard this sort of interest without promoting the legitimate interests of others. Here, too, however, the arguments really only support core doctrines within trademark law—especially rules against passing off counterfeit goods as the real thing, or some instances of so-called "reverse passing off," in which a person attempts to sell another's goods as though they were her own. ${ }^{2}$ Although copyright law prohibits some examples of plagiarism, in most situations it does so under very general directives not to reproduce or distribute

\footnotetext{
${ }^{2}$ See, e.g., Dastar Corp. v. Twentieth Century Fox Film Corp., 539 U.S. 23, 32 (2003).
} 
others' work that do not explicitly refer to copyright owners' interests in receiving attribution. ${ }^{3}$

Originally, however, copyright ownership included a right to decide when to release a new work for the first time, and this right to release can be understood as protecting individuals' interest in having control over their actions. ${ }^{4}$

But the core of patent and copyright law-the parts that prohibit unauthorized copying and distribution of patented inventions and copyrighted works—are justified not by natural rights arguments such as those that Locke and Kant supply, but by more functionalist lines of thought. For instance, innovators, artists, and others who invest in creative endeavors would be reluctant to devote their resources to developing and commercializing inventions and expressive works in the absence of special encouragement, because it is too easy for others to copy such goods without compensating the people who invested in their development. On this way of thinking, copyright and patent law are largely justified by the widely shared interests of the members of a society in the availability of new inventions and creative works, not by the interests of inventors or artists themselves. The fact that copyright and patent rights supply socially beneficial incentives has often been considered the heart of the utilitarian argument for intellectual property. I argued in Chapter 4, however, that we should resist the utilitarian label because utilitarianism characteristically directs us to formulate all normative questions in terms of the expected effects on overall amounts of well-

\footnotetext{
${ }^{3}$ But see 17 U.S.C. $§ 106 \mathrm{~A}(\mathrm{a})(1)-(2)$ (2006) (granting visual artists a right to attribution).

${ }^{4}$ Others' interests in having access to copyrighted works sometimes weigh against this right, however. Consider the example of a creative genius who has extremely high standards and insists on having her unfinished projects destroyed after her death. I find such cases much more difficult than cases in which someone merely publishes an uncompleted work without permission while its author is still in the process of developing it.
} 
being. If social welfare provides the only proper measure of intellectual property's justifications, policymakers' appeal to overtly nonutilitarian considerations will always seem like an aberration or even an inappropriate distraction. This is an unwelcome consequence, in my view, because the effects of intellectual property laws on social welfare are somewhat indeterminate and because other sorts of normative considerations are important enough in their own right even if, on balance, furthering them does not prove to maximize social welfare.

Consider, for example, a Kant-inspired argument for attribution rights: in light of an author's interest in controlling her actions and in having a reputation that accurately reflects what she has chosen to do, intellectual property law is justified in prohibiting others from falsely claiming credit for her work. It is conceivable, however, that this attribution right would present significant administrative and enforcement costs, and it is also conceivable that very few people would be seriously unhappy to see it go. Likewise, it is conceivable—-though I admit, not terribly likely— that social welfare would be increased if the law expressly empowered authors to sell their exclusive right to claim credit to the highest bidder. Even if it turned out that money would be saved or more books would be produced if the right to attribution were not legally recognized or were made transferable, I am not sure it follows that we ought to give up on recognizing a nontransferable version of it in our law. At the very least, it seems to me that we ought not to commit ourselves to designing our right to attribution in whatever way maximizes overall amounts of well-being solely because we think copyright law justified mainly because of the socially beneficial incentives it provides. 
My endorsement of the functionalist argument and rejection of Lockean and Kantian arguments for copyright and patent rights suggest a noteworthy difference between justifying intellectual property ownership as a matter of natural rights and justifying it as a matter of social convention: the two types of justification do not seem to face the same argumentative burden. Establishing that there are natural rights of intellectual property requires showing that a person or group's failure to respect the alleged right would warrant disapprobation, unless some sort of special excuse applied. Because failing to respect the particular right in question is presumptively a moral mistake, there must therefore be a decisive reason for respecting it. But for a social institution to have an adequate social convention-type justification, it suffices to establish that the institution serves the common good in an unobjectionable way. The reasons for establishing the particular institution need not be decisive. And yet, as I argued in Chapter 4, once a social institution is justified, even as a matter of social convention, it can have the power to generate new moral rights, respect for which is not completely optional. Our pre-legal or natural rights give shape to our legal institutions, but our legal institutions also give shape to our moral rights. The interplay between intellectual property rights and intellectual property institutions is thus highly complex and, without careful attention to the relevant normative considerations, even a bit mysterious. A pluralist account of intellectual property's justifications does not eliminate the complexity, but hopefully it dispels some of the mystery. 


\section{REFERENCES}

Abrams, Howard B. "The Historic Foundation of American Copyright Law: Exploding the Myth of Common Law Copyright," 29 Wayne L. Rev. 1119 (1983).

Adler, Amy M. “Against Moral Rights,” 97 Calif. L. Rev. 263 (2009).

Andersen, Peder. “'On Rent of Fishing Grounds': A Translation of Jens Warming's 1911 Article, with an Introduction,” 15 Hist. Pol. Econ. 391 (1983).

Anscombe, G.E.M. Intention (Harvard Univ. Press 2d ed. 2000) (1963).

Aristotle. Nicomachean Ethics, reprinted in 2 The Complete Works of Aristotle 1729 (Jonathan Barnes ed., W.D. Ross \& J.O. Urmson trans., 1984).

Aristotle. Politics, reprinted in 2 The Complete Works of Aristotle 1986 (Jonathan Barnes ed., B. Jowett trans., 1984).

Arrow, Kenneth J. "Economic Welfare and the Allocation of Resources for Invention" (1962), reprinted in Essays in the Theory of Risk-Bearing 144 (1971).

Athenaeus. The Deipnosophists (C.D. Yonge ed. \& trans., London, Henry G. Bohn 1854) (c. 230).

Attas, Daniel. "Lockean Justifications of Intellectual Property," in Intellectual Property and Theories of Justice 29 (Axel Gosseries et al. eds., 2008).

Austin, John. Lectures on Jurisprudence (Robert Campbell ed., 5th ed. 1885).

Banham, Rob. "The Industrialization of the Book 1800-1970," in A Companion to the History of the Book 273 (Simon Eliot \& Jonathan Rose eds., 2007).

Barron, Anne. "Kant, Copyright and Communicative Freedom,” 31 Law \& Phil. 1 (2012).

Becker, Gary S. Accounting for Tastes (1996).

Becker, Lawrence C. “Deserving to Own Intellectual Property," 68 Chi.-Kent L. Rev. 609 (1993).

Beitz, Charles R. “The Moral Rights of Creators of Artistic and Literary Works,” 13 J. Pol. Phil. 330 (2005).

Bentham, Jeremy. A Manual of Political Economy, in 3 The Works of Jeremy Bentham 30 (John Bowring ed. 1839). 
Bentham, Jeremy. An Introduction to the Principles of Morals and Legislation (Clarendon Press 1907).

Bentham, Jeremy. "Defence of Usury," in 3 The Works of Jeremy Bentham 1 (John Bowring ed. 1839).

Bentham, Jeremy. Theory of Legislation (Étienne Dumont \& Charles Milner Atkinson eds. \& trans., 1914) (1802).

Blackstone, William. Commentaries on the Laws of England (1765-1769).

Bowring, John. "History of the Greatest-Happiness Principle," in 1 Jeremy Bentham, Deontology 286 (John Bowring ed., 1834).

Brandt, Richard B. A Theory of the Good and the Right (1979).

Brink, David O. “Mill's Deliberative Utilitarianism,” 21 Phil. \& Pub. Aff. 67 (1992).

Broome, John. "Can There Be a Preference-Based Utilitarianism?," in Justice, Political Liberalism, and Utilitarianism: Themes from Harsanyi and Rawls 221 (Marc Fleurbaey et al. eds., 2008).

Brown, Horatio F. The Venetian Printing Press (New York, G.P. Putnam's Sons 1891).

Buckle, Stephen. Natural Law and the Theory of Property (1991).

Buss, Sarah. “Appearing Respectful: The Moral Significance of Manners," 109 Ethics 795 (1999).

Byrd, B. Sharon \& Joachim Hruschka. Kant's Doctrine of Right: A Commentary (2010).

Byrd, B. Sharon \& Joachim Hruschka. "The Natural Law Duty to Recognize Private Property Ownership: Kant's Theory of Property in his Doctrine of Right," 56 U. Toronto L.J. 218 (2006).

Carter, Stephen L. “Owning What Doesn't Exist,” 13 Harv. J.L. \& Pub. Pol'y 99 (1990).

Cass, Ronald A. \& Keith N. Hylton. Laws of Creation: Property Rights in the World of Ideas (2013).

Chang, Howard F. "A Liberal Theory of Social Welfare: Fairness, Utility, and the Pareto Principle,” 110 Yale L.J. 173 (2000).

Chang, Ruth. Introduction to Incommensurability, Incomparability, and Practical Reason 1 (Ruth Chang ed., 1997).

Chang, Ruth. “The Possibility of Parity," 112 Ethics 659 (2002). 
Cicero. De Officiis (Walter Miller trans., 1913) (44 B.C.).

Coleman, Jules L. “Doing away with Tort Law,” 41 Loy. L.A. L. Rev. 1149 (2008).

Craswell, Richard. "Incommensurability, Welfare Economics, and the Law," 146 U. Pa. L. Rev. 1419 (1998).

Crisp, Roger. Reasons and the Good (2006).

Cruft, Rowan. "Introduction to Symposium: Rights and the Direction of Duties," 123 Ethics 195 (2013).

Cullity, Garrett. “Moral Free Riding,” 24 Phil. \& Pub. Aff. 3 (1995).

Damstedt, Benjamin G. Note, "Limiting Locke: A Natural Law Justification for the Fair Use Doctrine,” 112 Yale L.J. 1179 (2003).

Darwall, Stephen. "Bipolar Obligation," in 7 Oxford Studies in Metaetbics 333 (Russ Shafer-Landau ed., 2012).

DaSilva, Russell J. "Droit Moral and the Amoral Copyright: A Comparison of Artists' Rights in France and the United States,” 28 Bull. Copyright Soc'y U.S.A. 1 (1980).

de Sousa, Ronald B. “The Good and the True," 83 Mind 534 (1974).

Donahue, Jr., Charles. “Animalia Ferae Naturae: Rome, Bologna, Leyden, Oxford and Queen's County, N.Y.," in Studies in Roman Law in Memory of A. Artbur Schiller (Roger S. Bagnall \& William V. Harris eds., 1986).

Drassinower, Abraham. "Copyright Infringement as Compelled Speech," in New Frontiers in the Philosophy of Intellectual Property 203 (Annabelle Lever ed., 2012).

Dworkin, Ronald. Taking Rights Seriously (1978).

Epstein, Richard A. Takings (1985).

Fallon, Jr., Richard H. “Should We All Be Welfare Economists?,” 101 Mich. L. Rev. 979 (2003).

Feinberg, Joel. “The Nature and Value of Rights,” 4 J. Value Inquiry 243 (1970).

Feinberg, Joel. "Voluntary Euthanasia and the Inalienable Right to Life," 7 Phil. \& Pub. Aff. 93 (1978). 
Filmer, Robert. Observations Concerning the Originall of Government (1652), reprinted in Patriarcha and Other Writings 184 (Johann P. Sommerville ed., Cambridge Univ. Press 1991).

Fischer, Klaus P. “John Locke in the German Enlightenment: An Interpretation,” 36 J. Hist. Ideas 431 (1975).

Fisher, William. "Theories of Intellectual Property," in New Essays in the Legal and Political Theory of Property 168 (Stephen R. Munzer ed., 2001).

Forster, John. The Life of Charles Dickens (1874).

Franklyn, David J. "Debunking Dilution Doctrine: Toward a Coherent Theory of the Anti-FreeRider Principle in American Trademark Law,” 56 Hastings L.J. 117 (2004).

Freke, John \& Edward Clarke. Letter to John Locke (Mar. 14, 1695), in 5 The Correspondence of Jobn Locke 291 (E.S. De Beer ed., 1979).

Fromer, Jeanne C. "Expressive Incentives in Intellectual Property," 98 Va. L. Rev. 1745 (2012).

Gaus, Gerald. "Property," in The Oxford Handbook of Political Philosophy 93 (David Estlund ed., 2012).

Goldberg, John C.P. \& Benjamin C. Zipursky. "Rights and Responsibility in the Law of Torts," in Rights and Private Law 251 (Donal Nolan \& Andrew Robertson eds., 2012).

Goldberg, John C.P. \& Benjamin C. Zipursky. “Torts as Wrongs,” 88 Tex. L. Rev. 917 (2010).

Gordon, H. Scott. "The Economic Theory of a Common-Property Resource: The Fishery," 62 J. Pol. Econ. 124 (1954).

Gordon, Wendy J. "A Property Right in Self-Expression: Equality and Individualism in the Natural Law of Intellectual Property,” 102 Yale L.J. 1533 (1993).

Gordon, Wendy J. "On Owning Information: Intellectual Property and the Restitutionary Impulse," 78 Va. L. Rev. 149 (1992).

Green, Leon. “Tort Law Public Law in Disguise” (pts. 1 \& 2), 38 Tex. L. Rev. 1 (1959-1960).

Griffin, James. Well-Being (1986).

Grotius, Hugo. De Juri Belli ac Pacis: Libri Tres (Francis W. Kelsey trans., Clarendon Press 1925) (1646). 
Hardin, Garrett. “The Tragedy of the Commons,” 162 Sci. 1243 (1968).

Harsanyi, John C. "Cardinal Welfare, Individualistic Ethics, and Interpersonal Comparisons of Utility,” 63 J. Pol. Econ. 309 (1955).

Hart, H.L.A. “Are There Any Natural Rights?,” 64 Phil. Rev. 175 (1955).

Hart, H.L.A. "Bentham on Legal Rights," in 2 Oxford Essays in Jurisprudence 171 (A.W.B. Simpson ed., 1973).

Hemingway, Ernest. A Farewell to Arms (Séan Hemingway ed., Scribner 2012).

Hettinger, Edwin C. “Justifying Intellectual Property," 18 Phil. \& Pub. Aff. 31 (1989).

Hobbes, Thomas. Leviathan (A. R. Waller ed., Cambridge Univ. Press 1904) (1651).

Hohfeld, Wesley Newcomb. Fundamental Legal Conceptions as Applied in Judicial Reasoning (Walter Wheeler Cook ed., 1920).

Holland, Thomas Erskine. The Elements of Jurisprudence (12th ed. 1916).

Holmes, O.W. “The Path of the Law," 10 Harv. L. Rev. 457 (1897).

Honoré, A.M. “Ownership,” in Oxford Essays in Jurisprudence 107 (A.G. Guest ed., 1961).

Hughes, Justin. "Locke’s 1694 Memorandum (and More Incomplete Copyright Historiographies)," 27 Cardozo Arts \& Ent. L.J. 555 (2010).

Hughes, Justin. “The Philosophy of Intellectual Property,” 77 Geo L.J. 287 (1988).

Hull, Gordon. "Clearing the Rubbish: Locke, the Waste Proviso, and the Moral Justification of Intellectual Property," 23 Pub. Aff. Q. 67 (2009).

Hume, David. A Treatise of Human Nature (L.A. Selby-Bigge \& P.H. Nidditch eds., Oxford Univ. Press 2d ed. 1978) (1739-1740).

Jefferson, Thomas. Letter to Isaac McPherson (Aug. 13, 1813), in 13 The Writings of Thomas Jefferson 326 (Albert Ellery Bergh ed., 1907).

Kamm, F.M. Intricate Ethics (2007).

Kant, Immanuel. “On the Wrongfulness of Unauthorized Publication of Books” (1785), reprinted in Practical Philosopby 23 (Mary J. Gregor ed. \& trans., Cambridge Univ. Press 1996). 
Kant, Immanuel. The Metaphysics of Morals (1797), reprinted in Practical Philosophy 353 (Mary J. Gregor ed. \& trans., Cambridge Univ. Press 1996).

Kaplow, Louis \& Steven Shavell. "Any Non-Welfarist Method of Policy Assessment Violates the Pareto Principle,” 109 J. Pol. Econ. 281 (2001).

Kaplow, Louis \& Steven Shavell. Fairness Versus Welfare (2002).

Katz, Larissa. "Ownership and Social Solidarity: A Kantian Alternative," 17 Legal Theory 119 (2011).

Keating, Gregory C. "Personal Inviolability and 'Private Law," 1 J. Tort L., no. 2, June 2007.

Klitzke, Ramon A. "Historical Background of the English Patent Law," 41 J. Pat. Off. Soc'y 615 (1959).

Knight, Frank H. Risk, Uncertainty, and Profit (1921).

Korsgaard, Christine M. "Kantian Ethics, Animals, and the Law," 33 Oxford J. Legal Stud. 629 (2013).

Korsgaard, Christine M. "The Relational Nature of the Good," in 8 Oxford Studies in Metaethics 1 (Russ Shafer-Landau ed., 2013).

Kramer, Matthew H. "Some Doubts About Alternatives to the Interest Theory of Rights," 123 Ethics 245 (2013).

Landes, William M. \& Richard A. Posner. “Trademark Law: An Economic Perspective," 30 J.L. \& Econ. 265 (1987).

Lee, Brian Angelo. "Making Sense of 'Moral Rights' in Intellectual Property," 84 Temp. L. Rev. 71 (2011).

Lemley, Mark A. “The Economics of Improvement in Intellectual Property Law," 75 Tex. L. Rev. 989 (1996).

Lemley, Mark A. \& Eugene Volokh. "Freedom of Speech and Injunctions in Intellectual Property Cases,” 48 Duke L.J. 147 (1998).

Locke, John. An Essay Concerning Human Understanding (Peter H. Nidditch ed., 1975) (1690).

Locke, John. "Labour," in Political Essays 326 (Mark Goldie ed., 1997) (1693). 
Locke, John. Letter to Richard King (Aug. 25, 1703), in 10 The Works of Jobn Locke, in Ten Volumes 305, 308 (London, J. Johnson et al. 1801).

Locke, John. "Liberty of the Press," in Political Essays 329 (Mark Goldie ed., 1997) (1694-1695).

Locke, John. "Some Thoughts Concerning Reading and Study for a Gentleman,” in Political Essays 348 (Mark Goldie ed., 1997) (1703).

Locke, John. Two Treatises of Government (Peter Laslett ed., Cambridge Univ. Press 1988) (1689).

Lyons, David. "Rights, Claimants, and Beneficiaries,” 6 Am. Phil. Q. 173 (1969).

MacCormick, D.N. "Rights in Legislation," in Law, Morality, and Society 189 (P.M.S. Hacker \& J. Raz eds., 1977).

Macpherson, C.B. The Political Theory of Possessive Individualism: Hobbes to Locke (1962).

Mandich, Giulio. “Venetian Patents (1450-1550),” 30 J. Pat. Off. Soc’y 166 (1948).

McGowan, David. “Copyright Nonconsequentialism,” 69 Mo. L. Rev. 1 (2004).

McKenna, Mark P. “The Normative Foundations of Trademark Law,” 82 Notre Dame L. Rev. 1839 (2007).

Melden, A.I. Rights and Persons (1977).

Merges, Robert P. Justifying Intellectual Property (2011).

Merges, Robert P. \& Richard R. Nelson. “On the Complex Economics of Patent Scope," 90 Colum. L. Rev. 839 (1990).

Merryman, John Henry. "The Public Law-Private Law Distinction in European and American Law,” 17 J. Pub. L. 3 (1968).

Merryman, John Henry. "The Refrigerator of Bernard Buffett," 27 Hastings L.J. 1023 (1976).

Mill, John Stuart. Principles of Political Economy (W.J. Ashley ed., 1909) (1848).

Mill, John Stuart. Utilitarianism (13th ed. 1906).

Moore, Adam D. Intellectual Property and Information Control (2d prtg. 2004). 
Mossoff, Adam. "The Use and Abuse of IP at the Birth of the Administrative State," 157 U. Pa. L. Rev. 2001 (2009).

Netanel, Neil. "Alienability Restrictions and the Enhancement of Author Autonomy in United States and Continental Copyright Law," 12 Cardozo Arts \& Ent. L.J. 1 (1994).

Nicholas, Barry. An Introduction to Roman Law (1962).

Nozick, Robert. Anarchy, State, and Utopia (1974).

Paine, Lynn Sharp. "Trade Secrets and the Justification of Intellectual Property: A Comment on Hettinger," 20 Phil. \& Pub. Aff. 247 (1991).

Patterson Lyman Ray. Copyright in Historical Perspective (1968).

Peterson, Jonathan. "Lockean Property and Literary Works," 14 Legal Theory 257 (2008).

Rawls, John. A Theory of Justice (rev. ed. 1999).

Rawls, John. “Two Concepts of Rules,” 64 Phil. Rev. 3 (1955).

Raz, Joseph. "Incommensurability and Agency," in Incommensurability, Incomparability, and Practical Reason 110 (Ruth Chang ed., 1997).

Raz, Joseph. "Rights and Individual Well-Being," 5 Ratio Juris 127 (1992).

Raz, Joseph. The Morality of Freedom (1986).

Regan, Donald. "Value, Comparability, and Choice," in Incommensurability, Incomparability, and Practical Reason 129 (Ruth Chang ed., 1997).

Ripstein, Arthur. “As If It Had Never Happened,” 48 Wm. \& Mary L. Rev. 1957 (2007).

Ripstein, Arthur. "Beyond the Harm Principle,” 34 Phil. \& Pub. Aff. 215 (2006).

Ripstein, Arthur. "Civil Recourse and Separation of Wrongs and Remedies," 39 Fla. St. U. L. Rev. 163 (2011).

Ripstein, Arthur. Force and Freedom: Kant's Legal and Political Pbilosopby (2009).

Ripstein, Arthur. “Tort Law in a Liberal State," 1 J. Tort L., no. 2, June 2007.

Ritter, Lawrence S. The Glory of Their Times (new enlarged ed. 1984). 
Rustad, Michael L. “Torts as Public Wrongs,” 38 Pepp. L. Rev. 433 (2011).

Ruston, Gerald. "On the Origin of Trademarks,” 45 Trademark Rep. 127 (1955).

Scanlon, T.M. "Natural Wrongs and Institutional Rights I: Property" (Feb. 1987) (unpublished manuscript).

Scanlon, T.M. What We Owe to Each Other (1998).

Searle, John R. "How to Derive 'Ought' from 'Is,” 73 Phil. Rev. 43 (1964).

Sen, Amartya. “The Impossibility of a Paretian Liberal,” 78 J. Pol. Econ. 152 (1970).

Sen, Amartya \& Bernard Williams. Introduction to Utilitarianism and Beyond 1 (Amartya Sen \& Bernard Williams eds., 1982).

Shavell, Steven. Foundations of Economic Analysis of Law (2004).

Shavell, Steven. "Should Copyright of Academic Works Be Abolished?," 2 J. Legal Analysis 301 (2010).

Shiffrin, Seana Valentine. "Lockean Arguments for Private Intellectual Property," in New Essays in the Legal and Political Theory of Property 138 (Stephen R. Munzer ed., 2001).

Sidgwick, Henry. The Elements of Politics (2d ed. 1897).

Sidgwick, Henry. The Method of Etbics (7th ed. 1907).

Sidgwick, Henry. The Principles of Political Economy (3d ed. 1901) (1883).

Simmons, A. John. “Makers' Rights,” 2 J. Ethics 197 (1998), reprinted in Justification and Legitimacy 249 (2001).

Simmons, A. John. The Lockean Theory of Rights (1992).

Sreenivasan, Gopal. The Limits of Lockean Rights in Property (1995).

Sunstein, Cass R. “Endogenous Preferences, Environmental Law,” 22 J. Legal Stud. 217 (1993).

Thompson, Michael. "What Is It to Wrong Someone? A Puzzle About Justice," in Reason and Value: Themes from the Moral Philosophy of Joseph Raz 333 (R. Jay Wallace et al. eds., 2004).

Thomson, Judith Jarvis. "Property Acquisition,” 73 J. Phil. 664 (1976). 
Treiger-Bar-Am, Kim. "Kant on Copyright: Rights of Transformative Authorship," 25 Cardozo Arts \& Ent. L.J. 1059 (2008).

Tully, James. A Discourse on Property: Jobn Locke and His Adversaries (1980).

Tushnet, Rebecca. "Copy This Essay: How Fair Use Doctrine Harms Free Speech and How Copying Serves It,” 114 Yale L.J. 535 (2004).

von Pufendorf, Samuel. Of the Law of Nature and Nations: Eight Books (Basil Kennett \& George Carew trans., London, J. Walthoe et al. 1729) (1672).

Waldron, Jeremy. "Enough and As Good Left for Others," 29 Phil. Q. 319 (1979).

Waldron, Jeremy. The Right to Private Property (1988).

Waldron, Jeremy. “Two Worries About Mixing One’s Labour,” 33 Phil. Q. 37 (1983).

Weinrib, Ernest J. "Private Law and Public Right,” 61 U. Toronto L.J. 191 (2011).

Weinrib, Ernest J. The Idea of Private Law (rev. ed. 2012).

White, G. Edward. Tort Law in America (expanded ed. 2003).

Woodward, James. “The Non-Identity Problem,” 96 Ethics 804 (1986).

Zemer, Lior. “The Making of a New Copyright Lockean,” 29 Harv. J.L. \& Pub. Pol'y 891 (2006).

Zipursky, Benjamin C. "Palsgraf, Punitive Damages, and Preemption,” 125 Harv. L. Rev. 1757 (2012).

Zuckert, Michael P. Natural Rights and the New Republicanism (1994). 